University of Chicago Law School

Chicago Unbound

Journal Articles

Scholarship

2020

\title{
The Failed Transparency Regime for Executive Agreements: An Empirical and Normative Analysis
}

\author{
Oona A. Hathaway \\ Curtis A. Bradley \\ Jack L. Goldsmith
}

Follow this and additional works at: https://chicagounbound.uchicago.edu/journal_articles

Part of the Law Commons

\section{Recommended Citation}

Hathaway, Oona A.; Bradley, Curtis A.; and Goldsmith, Jack L., "The Failed Transparency Regime for Executive Agreements: An Empirical and Normative Analysis" (2020). Journal Articles. 10208. https://chicagounbound.uchicago.edu/journal_articles/10208

This Article is brought to you for free and open access by the Scholarship at Chicago Unbound. It has been accepted for inclusion in Journal Articles by an authorized administrator of Chicago Unbound. For more information, please contact unbound@law.uchicago.edu. 


\title{
HARVARD LAW REVIEW
}

(C) 2020 by The Harvard Law Review Association

\author{
ARTICLES \\ THE FAILED TRANSPARENCY REGIME \\ FOR EXECUTIVE AGREEMENTS: AN EMPIRICAL \\ AND NORMATIVE ANALYSIS \\ Oona A. Hathaway, Curtis A. Bradley \& Jack L. Goldsmith \\ CONTENTS
}

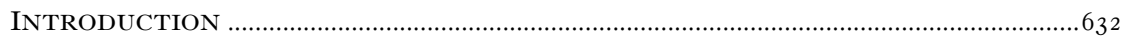

I. The Legal Regime for Executive Agreements............................................638

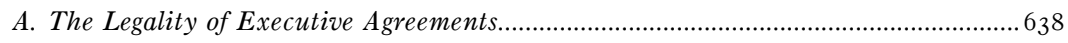

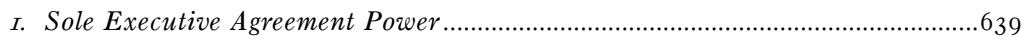

2. Implied Congressional Authorization to Make an Agreement ..............................64 I

3. International Agreements Consistent with Domestic Law...................................643

4. Authorization in a Prior Treaty or Agreement ………………………................644

B. The Transparency Regime for Executive Agreements ....................................................645

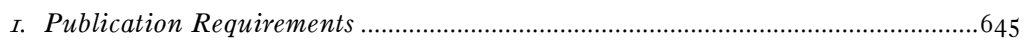

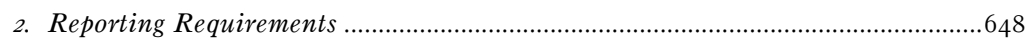

3. Periodic Congressional Concerns and Amendments ...........................................65 I

4. Other Transparency Requirements ........................................................................656

II. Does the Transparency Regime Work? An Empirical Assessment ......657

A. Qualitative Evidence: How Executive Agreements Are Made and Reported

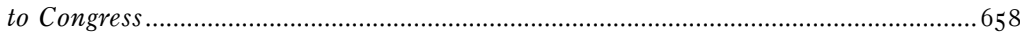

B. Quantitative Evidence: Assessing the Transparency and Legality of Executive

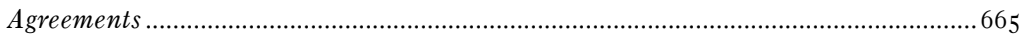

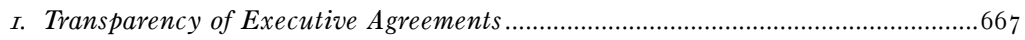

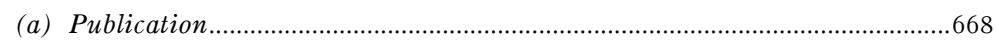

(b) Reporting ........................................................................................67 I

2. Legal Bases for Reported Agreements ......................................................................677

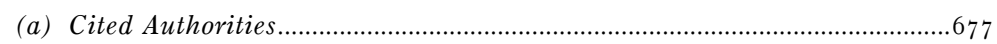

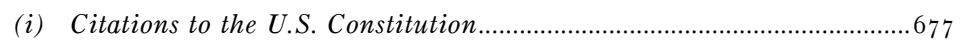

(ii) Citations to Authorities Other than the U.S. Constitution ......................677

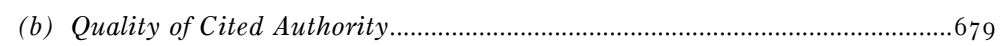

(c) Assessing Strength of Legal Authority for Each Agreement ...........................684 


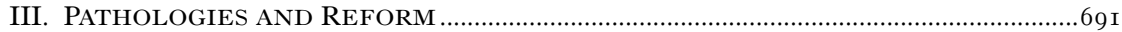

A. Improving the Collection and Reporting of Agreements ...............................................693

I. Transparency Issues that Emerge from the Data................................................694

2. Reform Proposals .......................................................................................697

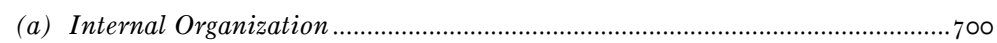

(b) Comprehensive Duty to Publish .........................................................................70I

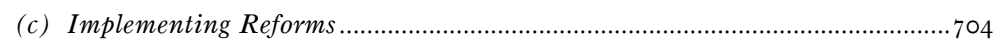

3. Political Commitments.............................................................................................. 708

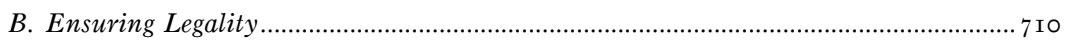

I. Legality Issues that Emerge from the Data .............................................................7 7 Iо

(a) Executive Agreements + ........................................................................ 7 I

(b) Ex Ante Congressional-Executive Agreements .............................................7 73

2. Reform Proposals .................................................................................................. 7 I 5

C. Reforms that Would Not Require Legislation ......................................................... 7 I 8

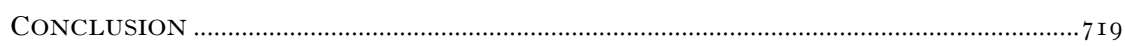

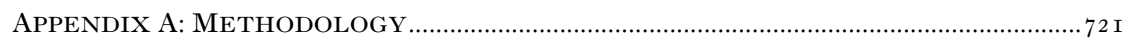

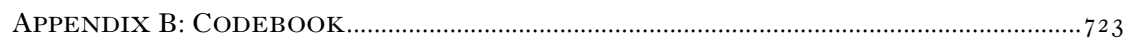




\title{
THE FAILED TRANSPARENCY REGIME FOR EXECUTIVE AGREEMENTS: AN EMPIRICAL AND NORMATIVE ANALYSIS ${ }^{\dagger}$
}

\author{
Oona A. Hathaway," Curtis A. Bradley ${ }^{* *}$ \& Jack L. Goldsmith ${ }^{* * * *}$
}

The Constitution specifies only one process for making international agreements. Article II states that the President "shall have Power, by and with the Advice and Consent of the Senate, to make Treaties, provided two thirds of the Senators present concur." The treaty process has long been on a path to obsolescence, however, with fewer and fewer treaties being made in each presidential administration. Nevertheless, the United States has not stopped making international agreements. Even as Article II treaties have come to a near halt, the United States has concluded hundreds of binding international agreements each year. These agreements, known as "executive agreements," are made by the President without submitting them to the Senate, or to Congress, at all. Congress has responded to the rise of executive agreements by imposing a transparency regime - requiring that all the binding executive agreements be reported to Congress and that important agreements be published for the public to see.

Until now, however, there has been no systematic assessment of how well the transparency regime has been working. This Article seeks to fill that gap. Through a Freedom of Information Act lawsuit, we obtained thousands of documents relating to the agreements reported to Congress and the legal authority on which the executive branch has relied for

$\dagger$ The Harvard Law Review has not independently reviewed the data and analyses described herein.

* Gerard C. and Bernice Latrobe Smith Professor of International Law, Yale Law School.

** William Van Alstyne Professor, Duke Law School.

*** Learned Hand Professor, Harvard Law School.

For helpful comments and suggestions, we thank Sue Biniaz, Kathy Bradley, Kathleen Claussen, Ashley Deeks, Kristen Eichensehr, Jean Galbraith, Monica Hakimi, Duncan Hollis, Mark Iozzi, Jamil Jaffer, Michael Mattler, David Pozen, Ryan Scoville, Margaret Taylor, and participants in a faculty workshop at Duke Law School and in the 20 I9 Duke-Virginia Foreign Relations Law Roundtable. For excellent research assistance, we thank Benjamin Fleshman, Michelle Lou, Eli Nachmany, Sam Rebo, and Abraham Sutton. For assistance with data collection and statutory analysis, we thank Andrea de Sa, Sasha Dudding, Pardis Gheibi, Katrin Marquez, and Danielle Zucker - who worked nearly two years on this project. We also thank Natalie Giotta, Ariq Hatibie, Kelsea Jeon, Christopher Kim, Tobias Kuehne, Julianna Lai, Sam Larkin, Jared LeBrun, Preston Lim, Randi Michel, Nicole Ng, Max Obmascik, John Park, Kate Pundyk, and Tiana Wang for their assistance in generating and quality controlling the data, and Andrea de Sa and Ayoub Ouederni for their outstanding assistance with analyzing the data. We thank the many government lawyers past and present who provided us with insights into the process for making executive agreements. We are grateful to Michelle Pearse, of the Harvard Law School Library, for assistance with creating the online repository of the data in this Article and to Evelyn Ma, Lucie Olejnikova, and the entire team at the Yale Law Library for their help on a number of research projects, including tracking down obscure sources. For assistance with the FOIA request and lawsuit against the Department of State (Yale Law School Center for Global Legal Challenges v. U.S. Department of State, No. I 7-cv-02042 (D. Conn. Dec. 7, 20I7)), we thank Hannah Bloch-Wehba, Charles Crain, Diana Lee, Paulina Perlin, and David Schultz of the Media Freedom and Information Access Clinic at Yale Law School. For their work on the data visualizations, see Oona A. Hathaway, Curtis A. Bradley \& Jack L. Goldsmith, The Failed Transparency Regime for Executive Agreements: An Empirical and Normative Analysis: Data Visualizations, HARV. L. REV. (Dec. IO, 2020), https://harvardlawreview.org/executive-agreements-visualizations, and Figures 1 and 3 in this Article, we thank Aucher Serr and Natalie Erdem, of Two-N. 
these agreements. Together with a series of interviews with lawyers directly involved in the process, this new information has given us an unprecedented look inside the system of concluding, publicizing, and reporting executive agreements. For the first time, we can describe how the system for making and scrutinizing executive agreements actually works - and when and how it fails to work. The overall picture that emerges is one of dysfunction and nonaccountability. In brief: there is reason to believe that the executive branch's reporting to Congress has been incomplete; the entire publication and reporting process is opaque to everyone involved, including executive branch officials and congressional staffers; and Congress is failing in its oversight role. The "system" is badly in need of repair if we are going to preserve the integrity and legality of the United States' primary means of making international commitments.

\section{INTRODUCTION}

$\mathrm{T}$ he Constitution specifies one process for making international agreements. Article II states that the President "shall have Power, by and with the Advice and Consent of the Senate, to make Treaties, provided two thirds of the Senators present concur." 1 The treaty process, however, is on a path to obsolescence. During President Trump's first three and a half years in office, he submitted only five treaties for Senate consent. This number represents a sharp drop compared to the Obama Administration (which submitted about five per year). The Obama Administration, in turn, submitted fewer treaties than the Bush Administration (which submitted around twelve per year). And the Bush Administration submitted many fewer treaties than the Clinton Administration (which submitted around twenty-three per year). ${ }^{2}$

The near collapse of the treaty process does not mean that the United States has stopped making international agreements. The Trump Administration, like prior administrations, has concluded hundreds of binding international agreements for the United States without submitting them to the Senate, or to Congress, at all. ${ }^{3}$ These agreements, known as "executive agreements," have long been the primary mechanism through which the United States makes international commitments. Since the late I930s, well over ninety percent of all international agreements concluded on behalf of the United States have been executive agreements rather than treaties. ${ }^{4}$ Many of these agreements involve

1 U.S. CONST. art. II, $\$ 2$, cl. 2 .

2 On President Trump's submissions, see Oona Hathaway, Reengaging on Treaties and Other International Agreements (Part I): President Donald Trump's Rejection of International Law, JUST SEC. (Oct. 2, 2020), https://www.justsecurity.org/72656/reengaging-on-treaties-and-other-internationalagreements-part-i-president-donald-trumps-rejection-of-international-law [https://perma.cc/6DBUUBBP]. On the other figures, see Jeffrey S. Peake, The Decline of Treaties? Obama, Trump, and the Politics of International Agreements 40 tbl.I (Apr. 6, 20I8) (unpublished manuscript), https:// papers.ssrn.com/sol $3 /$ papers.cfm?abstract_id=3 I53840 [https://perma.cc/9PQQ-M 3 EL].

3 See Treaties and Other International Acts Series (TIAS), U.S. DEP'T OF STATE, https://www.state.gov/tias [https://perma.cc/CFC8-BDSU] (follow hyperlinks for each year listed).

4 See Curtis A. Bradley \& Jack L. Goldsmith, Presidential Control over International Law, I 3 I HARV. L. REV. I20I, I 2 Io \& n. Io (20I8). There has also been some decline in the average number of executive agreements concluded per year since the Clinton Administration (including under President Trump), but the decline is not as sharp as for treaties. See Peake, supra note 2, at 40 tbl.I. 
minor or routine commitments, but some are quite consequential, involving matters such as security arrangements and alliances, the stationing of troops abroad, outlays of foreign aid, arrangements for border security, free trade accords, and weapons programs.

The main reason for the heavy reliance on executive agreements is that they are much easier to make than treaties. The Article II process requires a President to submit a negotiated treaty to the Senate for supermajority consent before the President can ratify and conclude it. By design, this is a very difficult process. In contrast, the primary form of executive agreement, known as an ex ante congressional-executive agreement, requires none of these steps. Instead, Congress in advance authorizes the President to make the agreement, usually in a statute that provides little concrete guidance. The authorization counts as full consent to the agreement prior to the President's negotiation of it. This means that the President can make and conclude the agreement, and thus render it legally binding on the United States, before Congress or the public even knows of its existence. This is also true of most other forms of executive agreements, including ones based on an authorization in a prior agreement and ones based on the President's constitutional powers alone.

Congress has gone along with these alternatives to the Article II treaty process with practically no substantive restrictions. Instead, it has imposed two general transparency requirements. First, since the late nineteenth century, it has required the executive branch to publish U.S. international agreements. The precise contours of this obligation have varied over time, but it has never resulted in anything close to complete public disclosure. Second, beginning with the 1972 Case Act, ${ }^{5}$ Congress has imposed a reporting requirement with broader reach: the Secretary of State must transmit to Congress, but need not make public, almost every international agreement other than an Article II treaty within sixty days after entry into force.

For a time, Congress also often included legislative veto provisions when delegating authority to conclude executive agreements. These provisions required the executive branch to send the negotiated agreement to Congress, prior to entry into force, so that Congress could examine the agreement and decide whether to disapprove it through onehouse or two-house vetoes. But this check ended with the Supreme Court's 1983 decision in INS v. Chadha,${ }^{6}$ in which the Court declared such vetoes to be unconstitutional. ${ }^{7}$ In response to Chadha, Congress

\footnotetext{
5 Pub. L. No. 92-403, 86 Stat. 6 I 9 (I972) (codified as amended at I U.S.C. § I I 2 b).

6462 U.S. 919 (1983).

7 Id. at 959 .
} 
amended many of the relevant statutes to strip out the legislative veto provisions, leaving just the bare delegations behind. ${ }^{8}$

As a result of Chadha, the only forms of accountability for the vast majority of executive agreements are a publication requirement for some agreements and a more comprehensive reporting requirement to Congress. These are very thin forms of accountability for such a consequential form of presidential lawmaking, especially as compared to the other major form of delegated executive branch lawmaking: administrative regulations. In contrast to regulations, executive agreements are only rarely publicized by the executive branch before they are concluded. This means that the public cannot consider the merits and potential effects of such an agreement before it becomes law. Another contrast is that the rules governing executive agreements do not require the executive branch to inform the public about their legal basis. There is also no institutionalized judicial review after agreements are concluded to ensure that they are properly authorized and justified. ${ }^{9}$ And many of the agreements are never made public, which means that citizens cannot monitor their content and operation even after the fact.

A vital but unanswered question of separation of powers and foreign relations law is how well this limited regime of ex post monitoring actually works. Does the executive branch publish and report as it should? When the President claims to be acting pursuant to congressional delegation, are such claims of authority persuasive? Does Congress pay attention to what the executive branch is doing, and perform its oversight role, in this realm?

The three authors of this Article are among the relatively small cadre of scholars who have written about the executive agreement process. One of us wrote an article more than a decade ago that emphasized that executive agreements had become the key mechanism for making U.S. international agreements - and therefore that the President acting practically alone had come to dominate international agreement making in the United States. ${ }^{10}$ That article attempted to understand when and how Congress had delegated authority to the President to make international agreements. But it had to guess at many important questions

8 See Oona A. Hathaway, Presidential Power over International Law: Restoring the Balance, I 9 YALE L.J. I40, 20I (2009) ("Congress responded in most cases either by eliminating the veto provision altogether, as it had in the case of the Foreign Assistance Act of I96I, or by rewriting it to require the full legislative process in place of the veto.").

9 Contrast this with the judicial review afforded agency actions. For example, in Department of Homeland Security v. Regents of the University of California, I40 S. Ct. I89I (2020), the Court blocked the Trump Administration's effort to end a major immigration program because the Court found the effort to be "arbitrary and capricious" under the Administrative Procedure Act (APA), 5 U.S.C. $\$ \S 55 \mathrm{I}, 553-559,70 \mathrm{I}-706$; I40 S. Ct. at I9I5, despite the executive branch's substantial authority to act in this area.

10 Hathaway, supra note 8, at I44. 
about how the process worked, including which agreements were reported to Congress and the actual legal basis for the international agreements. Two of us wrote an article more recently that analyzed international agreement making in the broader context of the President's other international lawmaking, law-interpreting, and law-terminating powers. ${ }^{11}$ This article too tried to understand how the accountability regime for executive agreements worked, and it included an extensive analysis of one of the nonpublic cover memos that the executive branch includes when it reports executive agreements to Congress under the Case Act. ${ }^{12}$ But this article also had to guess about how the reporting and transparency process worked in practice, as well as the legal basis for agreements generally. The lack of an empirical grounding left a significant gap in both articles - and is a serious problem in the entire literature on executive agreements.

We decided to address this empirical uncertainty by filing a Freedom of Information Act ${ }^{13}$ (FOIA) request with the State Department seeking the Case Act cover memos that the Department is required to send to Congress with every reported agreement. We hoped that these memos would give us a better sense of the Department's reporting practices under the Act. We also hoped that they would help us understand the claimed legal basis for the agreements, since almost every memo has a short section entitled "Legal Authority." After a lawsuit and a negotiated settlement, the State Department produced 5,689 cover memos reported from January 20 , I 989 , through January 20,2017 - that is, during the administrations of Presidents George H.W. Bush, William Clinton, George W. Bush, and Barack Obama.

The information that we have been able to glean from the cover memos - and from a series of interviews with lawyers directly involved in the executive agreement process - has given us an unprecedented look inside the system of concluding, publicizing, and reporting executive agreements. For the first time, we can describe how the system for making and scrutinizing executive agreements works - and when and how it fails to work. The overall picture that emerges is one of dysfunction and nonaccountability: there is reason to believe that the executive branch's reporting to Congress has been incomplete; the entire process is opaque to everyone involved, including executive branch officials and congressional staffers; and Congress is failing in its oversight role. There

\footnotetext{
11 See Bradley \& Goldsmith, supra note 4, at I 204-06.

12 See, e.g., id. at $1250-52$. Since $198 \mathrm{I}$, the State Department has been required by regulation to include with each agreement that it reports to Congress under the Case Act a "background statement" that "shall include information explaining the agreement and a precise citation of legal authority." 22 C.F.R. § I8I.7(c) (20I9); see infra p. 650.

135 U.S.C. $\S 55^{2}$.
} 
are also substantial questions about the underlying legal authority for an appreciable number of the agreements. ${ }^{14}$

Part I of this Article describes the legal regime governing executive agreements. It begins by describing the various types of executive agreements and the scope of the executive branch's legal authority to conclude them. Next, it reviews what we call the "transparency regime" for executive agreements - the way in which Congress has regulated executive agreements not by requiring that the agreements be individually approved after they are negotiated, but instead by mandating disclosure to Congress itself and to the public after the agreement is concluded. This review makes clear that while Congress has been content to delegate authority to make executive agreements to the executive branch, it has repeatedly intervened in an effort to effectively observe and monitor how that authority is used.

Part II considers how the process of concluding executive agreements works in practice. It begins with information obtained from a dozen interviews with current and former government lawyers about how the process of concluding executive agreements actually takes place. These interviews were necessary because the process occurs entirely out of public view, and the regulatory guidance reveals only the basic outlines. That qualitative information then informs our quantitative assessment of the process of making executive agreements. We use data gleaned from the more than 5,000 cover memos obtained from the State Department to compare what is made public with what is reported to Congress. This comparison reveals that much of what is reported to Congress is never made public. More troublingly, if we treat the cover memos as evidence of the unclassified agreements that the executive branch reported to Congress, it seems likely that the executive branch has failed to comply fully with the reporting obligations that Congress has imposed.

The cover memos also permit us for the first time to discern the legal authorities cited in support of the agreements. By studying the thousands of citations to legal authorities in the cover memos based on the

\footnotetext{
14 It bears emphasizing that our study focuses exclusively on unclassified executive agreements. The existence of classified agreements compounds the transparency and legality issues. See Cong. Rsch. Serv., io6Th Cong., Treaties And Other International Agreements: The Role of the United States Senate 226 tbl.X-i (Comm. Print 200I) [hereinafter CRS TREATY STUDY] (showing the number of executive agreements reported to Congress from I978I 999; approximately r.65\% are listed as classified); Ashley S. Deeks, A (Qualified) Defense of Secret Agreements, 49 ARIZ. ST. L.J. 7I3, 724 (20I7) (estimating that "the United States is probably party to approximately I,000-I,800 secret agreements"); Ryan Scoville, New Evidence of Secret International Agreements, LAWFARE (Feb. I9, 2020, I0:23 AM), https://www.lawfareblog.com/new-evidence-secret-international-agreements [https://perma.cc/ $\mathrm{H}_{42} \mathrm{G}_{3} \mathrm{SJH}$ ] (finding that "the United States continues to enter into classified agreements with considerable frequency").
} 
strength of the authority granted for concluding agreements, we can assess how the executive branch invokes delegated authority from Congress to make agreements. Here we find that less than half of the cover memos cite an authority that gives the executive branch clear and express authority to conclude a binding international agreement. ${ }^{15} \mathrm{Al}-$ most one-fifth of the memos cite legal authorities that in our assessment offer no support for concluding an agreement. ${ }^{16}$ Moreover, the cover memos frequently cite Article II of the U.S. Constitution in addition to other legal authorities; there is very little distinction made between agreements that rely entirely on the President's sole constitutional authority and those that rely on authority granted by Congress or by virtue of a prior treaty. Indeed, perhaps the most remarkable thing that we discovered in the process of attempting to analyze and describe how the transparency regime works in practice is how disorganized the system is. Multiple legal authorities are cited without any clarity about the central legal basis for concluding an agreement, the legal authorities are not cited systematically or carefully, public databases of agreements are woefully lacking, and reporting to Congress is slow and likely incomplete.

Part III turns to proposed solutions. These fall into two categories. First, our proposals aim to remedy problems in publication and reporting. It is time, we contend, for the revolution of organization and transparency that took place for federal regulations at the dawn of the New Deal to extend to executive agreements. To that end, we propose to do away with the bifurcated regime and simply impose a comprehensive publication requirement, with minor exceptions, akin to the one that has long been in place for federal regulations. We also propose to reorganize the internal executive branch process for collecting and publishing along the lines of the process that governs federal regulations. As we explain, these reforms should be normatively uncontroversial, and they are dramatically easier to carry out today than they would have been in the twentieth century due to the digitalization of information.

Second, we address the uncertain legality of many of the agreements. We propose that Congress require the executive branch to offer greater transparency regarding the legal basis for international agreements and clarity about the source of legal authority on which the government relies. A simple solution would be to publish the cover memos themselves - rather than keep them hidden from public view - and require that they cite a primary legal authority. These and related reforms will, we believe, make it more likely that agreements in the future will possess an adequate legal basis.

We should emphasize at the outset that while we are very critical of the current reporting and publication system for executive agreements,

15 See infra section II.B.2, pp. 677-9I.

16 See infra section II.B.2, pp. 677-9I. 
we do not believe that the blame for this dysfunction lays at the feet of any particular branch of government or particular agencies or individuals inside the executive branch. The dysfunction is the product of decades of neglect, secrecy, disorganization, resource constraints, and misplaced priorities, in both Congress and the executive branch. The current system is not admired by anyone in the government or serving any institution's interest. Reform is clearly needed, as many of our executive branch and congressional interview subjects themselves acknowledged. While some of our proposed reforms will be more difficult to implement than others, there should be broad agreement, across parties and across the political branches of government, that the system is badly in need of repair.

\section{The Legal Regime For ExeCUTIVE AGReEMENTS}

This Part sets forth the legal background for the analysis that follows. It begins by reviewing the various types of executive agreements and the scope of the executive branch's legal authority to conclude them. It then describes the transparency regime that Congress has crafted in an effort to ensure that these agreements are subject to oversight and accountability.

\section{A. The Legality of Executive Agreements}

Executive agreements are commonly grouped into one of four categories based on the type of authorization that supports the agreement. A "sole executive agreement" is concluded by the President on his or her own constitutional authority without any express congressional authorization or approval. ${ }^{17}$ An "ex ante congressional-executive agreement," which is the most common type of executive agreement, is authorized in advance by statute and concluded by the executive branch without subsequent congressional review or approval. ${ }^{18}$ An "executive agreement pursuant to treaty" is authorized by a prior treaty or international agreement. ${ }^{19}$ Least common (and not the focus of this section) is an "ex post congressional-executive agreement," which is approved by a majority of Congress after it is negotiated. ${ }^{20}$

Executive agreements date back to early in U.S. history. In I 792, for example, Congress authorized the Postmaster General to conclude ex ante congressional-executive agreements concerning the international exchange of mail. ${ }^{21}$ Presidents also sometimes made sole executive

\footnotetext{
17 See Bradley \& Goldsmith, supra note 4, at I 208.

18 See id. at I2 I3.

19 See id. at I207-08.

20 See id. at I2 I2.

21 See Act of Feb. 20, I 792, ch. 7, § 26, I Stat. 232, 239.
} 
agreements in the early days of the nation - for example, to settle claims with foreign nations. ${ }^{22}$ But Article II treaties were the predominant process for making international agreements in the first fifty years of the nation's history and continued to be a mainstay of agreement making until World War II. ${ }^{23}$ Since then, executive agreements, and especially ex ante congressional-executive agreements, have come to be the dominant form of international agreement making by the United States. ${ }^{24}$ Between the late I930s and the end of the Obama Administration, only about six percent of the United States' international agreements were concluded as Article II treaties. ${ }^{25}$ All the rest were some form of executive agreement. ${ }^{26}$ As noted in the Introduction, the percentage of agreements that were concluded as Article II treaties has been even lower during the past several presidential administrations. ${ }^{27}$

In part because of longstanding historical practice, it is undisputed that the executive branch has some legal authority to conclude executive agreements. But this authority is limited. Executive agreements, like Article II treaties, create fully binding legal obligations for the United States under international law. As is true of every action of the federal government, executive agreements must be authorized by the Constitution or a prior federal enactment. ${ }^{28}$ For each of the categories of executive agreements, the type of authorization that is required carries with it particular limitations. In reviewing these limitations, we begin with sole executive agreements, which are based on constitutional authorization, and then we move to agreements that are authorized by statute or treaty.

I. Sole Executive Agreement Power. - Courts and other interpreters commonly give weight to longstanding executive branch practice in assessing presidential authority, at least if the practice has been acquiesced

22 See Samuel B. Crandall, Treaties: Their Making And Enforcement $\$ 57$, at I08-09 (2d ed. I9I6); Michael D. Ramsey, Executive Agreements and the (Non)Treaty Power, 77 N.C. L. REv. I33, I74-75 (I998); see also Dames \& Moore v. Regan, 453 U.S. 654, 679 (I98I) ("Though those settlements [of claims by U.S. nationals against foreign nations] have sometimes been made by treaty, there has also been a longstanding practice of settling such claims by executive agreement without the advice and consent of the Senate.").

23 See Hathaway, supra note 8, at I69-8I; Ramsey, supra note 22 , at I $7 \mathrm{I}-83$.

24 See Hathaway, supra note 8, at 167-205 (describing this change and the reasons for it).

25 See Bradley \& Goldsmith, supra note 4, at 12 го.

26 On the many political and legal reasons why the United States shifted sharply toward the use of executive agreements after World War II, see Bruce Ackerman \& David Golove, Is NAFTA Constitutional?, I08 HARV. L. REV. 799, 86 I-66 (I995); and Oona A. Hathaway, Treaties' End: The Past, Present, and Future of International Lawmaking in the United States, I 7 YALE L.J. I236, I 292-302 (2008).

27 See Bradley \& Goldsmith, supra note 4, at I 2 IO-I2.

28 On the general principle of the need for authorization for government action, see, for example, Medellín v. Texas, $55_{2}^{2}$ U.S. 49I, 524 (2008); Bowen v. Georgetown Univ. Hosp., 488 U.S. 204, 208 (i988); Dames \& Moore v. Regan, 453 U.S. 654, 668 (I98I); and Youngstown Sheet \& Tube Co. v. Sawyer, 343 U.S. 579, 585 (I952). 
in by Congress. ${ }^{29}$ As a result, a full assessment of the President's constitutional authority to make sole executive agreements would require an in-depth assessment of historical practice, something that is beyond the scope of this Article. Nevertheless, it is possible to identify the general outlines of presidential authority in this area and some of the likely limitations on that authority.

First, Presidents have some authority to conclude sole executive agreements that relate to their independent constitutional powers. ${ }^{30}$ The President's commander-in-chief power, for example, has often served as a source of authority for some military-related agreements, such as agreements to exchange prisoners, conduct joint military exercises, or engage in a ceasefire. ${ }^{31}$ Similarly, the President's implied power to recognize foreign sovereigns and their territory has been thought to include some authority to conclude agreements facilitating the recognition. ${ }^{32}$ Presidents have also long used their powers over diplomacy to enter into executive agreements settling international claims against foreign governments. ${ }^{33}$ And Presidents have sometimes entered into short-term agreements, such as modi vivendi, in order to preserve the status quo pending negotiation of more final arrangements, although it is often unclear whether these agreements are binding under international law or are mere political commitments. ${ }^{34}$

The four Supreme Court decisions that have addressed sole executive agreements are all consistent with the need to tie such agreements to an independent presidential power. ${ }^{35}$ Two of these decisions concerned an agreement to effectuate President Franklin Roosevelt's recognition of the Soviet Union and to settle claims with that country. ${ }^{36}$ The third

29 See, e.g., Zivotofsky v. Kerry, I35 S. Ct. 2076, 209I (2015); NLRB v. Noel Canning, 573 U.S. 5I3, 524 (20I4); see also Curtis A. Bradley \& Trevor W. Morrison, Historical Gloss and the Separation of Powers, I26 HARV. L. REV. 4II (2OI2).

30 See Restatement (ThiRd) of the Foreign Rels. L. of the United States § 303(4) (AM. L. INST. I987) ("[T]he President, on his own authority, may make an international agreement dealing with any matter that falls within his independent powers under the Constitution.").

31 See Restatement (SECOND) OF Foreign Rels. L. OF the United States § i 2 i cmt. b (AM. L. INST. I 965) ("A large proportion of the international agreements made under the powers of the President and intended to create legal relationships under international law have been based on his power as commander-in-chief and have provided for the conduct of military operations with allies of the United States.").

32 See, e.g., United States v. Belmont, 30I U.S. 324, 330 (I937) ("The recognition, establishment of diplomatic relations, the assignment, and agreements with respect thereto, were all parts of one transaction, resulting in an international compact between the two governments.").

33 See Crandall, supra note $22, \S_{57}$, at IO9-II; QUincy Wright, The Control of AMERICAN FOREIGN RELATIONS 237-40 (I922).

34 See CRANDALL, supra note $22, \S 59$, at I I $2-14$.

35 See Am. Ins. Ass'n v. Garamendi, 539 U.S. 396, 4I4-I 5 (2003); Dames \& Moore v. Regan, 453 U.S. 654, 682-83 (I98I); United States v. Pink, 315 U.S. 203, 229 (I942); Belmont, 30I U.S. at 330.

36 See Pink, 3I5 U.S. at 2 I I-I4; Belmont, 30I U.S. at 326-27, 330. 
decision concerned an agreement to resolve a national security crisis with Iran and, again, to settle claims between the two countries. ${ }^{37}$ And the fourth agreement, too, involved a settlement of claims, albeit one involving claims against private companies for actions taken in the World War II era. ${ }^{38}$ Importantly, in its most recent statement on the subject, the Supreme Court emphasized that even the long-established presidential power to settle claims is "narrow and strictly limited." 39

Second, whatever the precise scope of the President's power to conclude sole executive agreements, this power is substantially narrower than the power to enter into Article II treaties. This proposition follows from constitutional text and structure. The Constitution specifies that the President must obtain legislative approval for treaties. ${ }^{40}$ The Framers believed that such legislative consent was crucial because international commitments have important consequences for the nation that should not be decided by one person atop the executive branch. ${ }^{41}$ The preservation of this principle of legislative-executive collaboration for international lawmaking is the main reason why the large-scale substitution of congressional-executive agreements for treaties has been deemed legitimate. ${ }^{42}$ The principle would effectively be nullified if the President could make a wide range of executive agreements without any congressional consent. ${ }^{43}$

2. Implied Congressional Authorization to Make an Agreement. Whatever the precise scope of the sole executive agreement power, it is clear that a President has broader authority to conclude executive agreements when authorized to do so by Congress. As Justice Jackson explained in his famous concurrence in Youngstown Sheet \& Tube Co. $v$. Sawyer"4: "When the President acts pursuant to an express or implied authorization of Congress, his authority is at its maximum, for it includes all that he possesses in his own right plus all that Congress can

37 See Dames \& Moore, 453 U.S. at 662-68.

38 See Garamendi, 539 U.S. at $40 \mathrm{I}-02$.

39 Medellín v. Texas, $55^{2}$ U.S. 49I, 532 (2008).

40 See U.S. CONST. art. II, $\$ 2$, cl. 2.

41 See, e.g., The Federalist No. 75, at 450 (Alexander Hamilton) (Clinton Rossiter ed., 2003) (explaining that it would be unwise "to commit interests of so delicate and momentous a kind, as those which concern [this country's] intercourse with the rest of the world, to the sole disposal of a magistrate created and circumstanced as would be a President of the United States"); see also Ramsey, supra note 22, at I92 "Affording the President unilateral control over entry into such agreements ... would award substantial power to the President and would be inconsistent with the emphasis on the checking power of the Senate.").

42 See Ackerman \& Golove, supra note 26, at 86 I-65; Hathaway, supra note 26, at I306-I 2.

43 See, e.g., Louis Henkin, Foreign AfFaIRs AND the United STATes CONSTITUTION 222 (2d ed. I996) (noting that full interchangeability of sole executive agreements with Article II treaties would be "unacceptable, for it would wholly remove the 'check' of Senate consent which the Framers struggled and compromised to write into the Constitution"); see also I LaUrence H. Tribe, American CONSTItutional LaW § 4-4, at 649 (3d ed. 2000).

44343 U.S. 579 (I952). 
delegate." ${ }^{45}$ A complicating factor here is that congressional authorization can be implied rather than express. ${ }^{46}$ Discerning implied congressional intent can be a difficult enterprise that may turn on a variety of considerations, including the historical practice against which Congress has legislated and the extent to which the agreement relates to independent presidential authority. ${ }^{47}$

The Supreme Court's decision in Dames \& Moore v. Regan ${ }^{48}$ illustrates the difficulty of this inquiry. The issue there was whether the President had the authority to suspend American claims against Iran as part of a regulatory implementation of a sole executive agreement with Iran to resolve the I979-I98 I hostage crisis. ${ }^{49}$ The Court observed that the statutes invoked by the executive branch in support of the regulations - the International Emergency Economic Powers Act and the Hostage Act did not specifically authorize the presidential suspension of claims..$^{50}$ But, the Court noted, the executive branch had long asserted a sole executive agreement power under Article II to settle international claims, and Congress had long "acquiesced" in that power ${ }^{51}$ — and indeed had "implicitly approved" it ${ }^{52}$ in the International Claims Settlement Act of $1949 .{ }^{53}$

Based on "the inferences to be drawn from the character of the legislation Congress has enacted in the area" and "from the history of acquiescence in executive claims settlement," the Court concluded that "the President was authorized to suspend" the claims. ${ }^{54}$ The Court also emphasized, however, the "narrowness" of its decision, involving a context in which "the settlement of claims has been determined to be a necessary incident to the resolution of a major foreign policy dispute between our country and another, and where... we can conclude that Congress acquiesced in the President's action." ${ }^{55}$

In short, Presidents will sometimes have the authority to conclude executive agreements based on an implicit authorization from Congress. As we explain in detail in Parts II and III, discerning such authorization requires a context-specific inquiry. Ultimately, however, this is a matter of statutory construction, and not all statutes conferring authority on the

\footnotetext{
45 Id. at 635 (Jackson, J., concurring).

46 See id.; Bradley \& Goldsmith, supra note 4 , at 1263.

47 For an extended analysis of the relevance of these considerations, see Bradley \& Goldsmith, supra note 4 , at I $264-65$.

48453 U.S. 654 (I98I).

49 See id. at 662-68.

50 Id. at $662,675-77$.

51 Id. at 688 .

$52 \mathrm{Id}$. at 680 .

53 Id. at $680,688$.

$54 \mathrm{Id}$. at 686 .

$55 \mathrm{Id}$. at 688.
} 
executive branch can fairly be read to authorize the conclusion of international agreements.

3. International Agreements Consistent with Domestic Law. Professors Dan Bodansky and Peter Spiro have argued that Presidents have the authority to enter into what they refer to as "Executive Agreements+." ${ }^{" 5}$ An Executive Agreement+ is an agreement made by the executive branch that neither relates to an independent presidential power nor is specifically authorized by Congress. ${ }^{57}$ Its legal justification, instead, is that it "complement[s]" or is "consistent with" existing federal law. ${ }^{58}$ The idea seems to be that if Congress regulates a matter under domestic law but does not otherwise authorize the making of international agreements relating to the subject matter, the executive branch can nonetheless make an international agreement on the topic "in order to address the transnational aspects of a problem." 59

The Legal Adviser to the State Department in the Obama Administration, Harold Koh, embraced a version of the Executive Agreements+ idea while defending the legality of concluding the AntiCounterfeiting Trade Agreement ${ }^{60}$ (ACTA) without legislative approval. ACTA was a controversial multilateral treaty designed to enhance intellectual property enforcement. ${ }^{61}$ The U.S. Trade Representative initially suggested that it could be concluded as a sole executive agreement. ${ }^{62}$ In response to criticism from Senator Ron Wyden and scholars, ${ }^{63}$ Koh offered a different rationale. ${ }^{64}$ He maintained that, although the agreement had not been specifically authorized by Congress, the government

56 Daniel Bodansky \& Peter Spiro, Executive Agreements+, 49 VAND. J. Transnat'L L. 885, 887 (2016).

57 See id. (defining an Executive Agreement+ as an international agreement "in the absence of ex ante or ex post congressional authorization, respecting issues beyond independent Presidential authority"); $i d$. at 897 (noting that Executive Agreements+ are not "congressional-executive agreements, since they lack congressional authorization or approval").

58 Id. at 889 ; see id. at $887-89$.

59 Id. at 915 ; see id. at 927.

60 Oct. I, 20 I I, 50 I.L.M. 243.

61 See ACTA: Controversial Anti-piracy Agreement Rejected by EU, BBC NEWs (July 4, 2012), https://www.bbc.com/news/technology-I8704192 [https://perma.cc/CAK9-M68U].

62 See Sean Flynn, ACTA's Constitutional Problem: The Treaty Is Not a Treaty, 26 AM. U. INT'L REV. 903, 904 (20II).

63 See Jack Goldsmith, The Doubtful Constitutionality of ACTA as an Ex Ante CongressionalExecutive Agreement, LAWFARE (May 2 I, 201 2, I:03 PM), https://www.lawfareblog.com/doubtfulconstitutionality-acta-ex-ante-congressional-executive-agreement [https://perma.cc/Y 7 BB-W8SZ]; Press Release, Ron Wyden, U.S. Sen., Wyden to President: Isn't Congress Supposed to Approve International Trade Agreements? (Oct. I2, 20II), https://www.wyden.senate.gov/news/pressreleases/wyden-to-president-isnt-congress-supposed-to-approve-international-trade-agreements [https://perma.cc/J93F-LW 77]; Letter from Law Professors to Members of the United States Senate Comm. on Fin. (May i6, 20I2), http://infojustice.org/wp-content/uploads/2012/o5/Law-ProfessorLetter-to-Senate-Finance-Committee-May-I6-20 2 2 2.pdf [https://perma.cc/RQ8Y-AP42]

64 See Letter from Harold Hongju Koh, Legal Adviser, U.S. Dep't of State, to Ron Wyden, U.S. Sen. (Mar. 6, 20I2), http://infojustice.org/wp-content/uploads/2012/03/84365507-State-Department- 
had authority under "existing U.S. intellectual property law" to take the actions required by it. ${ }^{55} \mathrm{He}$ further noted that Congress had called for the executive branch to "work[] with other countries to establish international standards and policies for the effective protection and enforcement of intellectual property rights." 66 Koh argued that this was enough for the executive branch to conclude ACTA. ${ }^{67}$ And he maintained more broadly that the executive branch can conclude binding international agreements in every instance in which it "determine[s] that the negotiated agreement fit[s] within the fabric of existing law, [is] fully consistent with existing law, and [does] not require any further legislation to implement." 68

We have criticized elsewhere the idea that Presidents can make binding international agreements based merely on a claim of consistency with domestic law, and we will not repeat those arguments here. ${ }^{69}$ Suffice it to say that the idea seems difficult to reconcile with the proposition, noted above, that all governmental actions must be authorized by the Constitution or by Congress. One could argue that Congress has in fact authorized this broad executive agreement authority (in the Dames $\&$ Moore sense of authorization) through acquiescence in a longstanding pattern of executive branch practice. ${ }^{70}$ Bodansky and Spiro, however, do not make such a claim. They instead acknowledge that the executive branch practice they describe is "not yet constitutionally entrenched." 11 We would also note that, under most accounts of how congressional acquiescence can enhance executive authority, Congress must at least be aware of the executive branch's assertions of authority in order to be said to "acquiesce" in them. As will become clear in Part II, it is doubtful that this is the case here.

4. Authorization in a Prior Treaty or Agreement. - Just as an executive agreement can be authorized by statute, it can also be authorized

\footnotetext{
Response-to-Wyden-on-ACTA.pdf [https://perma.cc/9BF8-LA2P]; Letter from Ron Wyden, U.S Sen., to Harold Koh, Legal Adviser, U.S. Dep’t of State (July 25, 20I2), https://www.wyden.

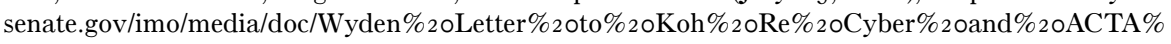
20July\%2020I 2.pdf [https://perma.cc/5 $\left.\mathrm{TJ}_{4}-2 \mathrm{YDF}\right]$.

65 Letter from Harold Hongju Koh, supra note 64, at I.

$66 \mathrm{Id}$. at 2 (alteration in original) (quoting I5 U.S.C. § 8 I I $3(\mathrm{a})(6))$.

67 Id. at $\mathrm{I}-2$.

68 Harold Hongju Koh, Triptych's End: A Better Framework to Evaluate 2 Ist Century International Lawmaking, I26 YALE L.J.F. 338, 343 (2017).

69 See Bradley \& Goldsmith, supra note 4, at I 260-63; Oona A. Hathaway \& Amy Kapczynski, Going It Alone: The Anti-counterfeiting Trade Agreement as a Sole Executive Agreement, AM. SOC'Y INT'L L.: INSIGHTS (Aug. 24, 20II), https://www.asil.org/insights/volume/I $5 /$ issue/23/ going-it-alone-anti-counterfeiting-trade-agreement-sole-executive [https://perma.cc/4CYW-HGgK].

70 Koh lists "widespread and consistent practice of [e]xecutive [b]ranch activity that Congress, by its conduct, has essentially accepted" as one of several factors that might support an executive agreement. Koh, supra note 68 , at 343 .

71 Bodansky \& Spiro, supra note 56, at 890.
} 
by a prior Article II treaty or a congressionally authorized agreement. ${ }^{72}$ Although this category of executive agreements has been relatively uncontroversial, the same basic considerations that apply to statutory authorizations apply here. The principal issue is whether the prior treaty or agreement truly authorizes the executive agreement that relies on it, and the most difficult cases will be those involving claims of implicit authorization..$^{73}$

\section{B. The Transparency Regime for Executive Agreements}

This section describes the oversight tools that Congress has deployed in response to the sharp rise of executive agreements. We call these tools the "transparency regime" for executive agreements because they focus primarily on keeping Congress and (to a lesser extent) the public informed about these agreements. We will detail how the transparency regime works, what it requires, and how Congress has amended and changed it over the years in response to concerns about executive branch noncompliance.

I. Publication Requirements. - Before I950, the official publication source for treaties and executive agreements was the Statutes at Large. ${ }^{74}$ The Public Printing Act of $1895^{75}$ required the Secretary of State, at the end of each Congress, to edit, print, bind, and distribute the Statutes at Large containing not only "all laws[ and] joint and concurrent resolutions passed by Congress," but also "all conventions, treaties, proclamations, and agreements." "In practice," as the Congressional Research Service has noted, "a number of agreements escaped publication," and eventually "a hodgepodge of published bits and pieces was developed." 77

When the Administrator of General Services took over the publication of the Statutes at Large from the Secretary of State in I950, Congress enacted a publication statute for treaties and executive agreements that is still operative today. ${ }^{78}$ This statute, I U.S.C. $\S$ I I $2 \mathrm{a}$, directed the Secretary of State to "cause to be compiled, edited, indexed, and published" a yearly compilation containing:

\footnotetext{
72 See Bradley \& Goldsmith, supra note 4, at I $267-68$.

73 See CRS TREATY STUDY, supra note 14 , at 86 ("Agreements in this category comprise those which are expressly authorized by the text of an existing treaty or whose making may be reasonably inferred from the provisions of a prior treaty." (emphasis added)).

74 See id. at 2 IO.

75 Ch. 23, 28 Stat. 60I.

76 Id. $\$ 73,28$ Stat. at 6 I 5 .

77 CRS TREATY STUDY, supra note $\mathrm{I} 4$, at $2 \mathrm{IO}$.

$78 \mathrm{Id}$. at 2 IO-II; I U.S.C. § I I 2 a.
} 
all treaties to which the United States is a party that have been proclaimed during each calendar year, and all international agreements other than treaties to which the United States is a party that have been signed, proclaimed, or with reference to which any other final formality has been executed. ${ }^{79}$

This yearly publication is referred to as "United States Treaties and Other International Agreements" (UST). It was originally compiled from agreements published in "slip" form by the State Department in the Treaties and Other International Acts Series (TIAS), a series that dates to I946. Because of funding limitations, the Government Printing Office has stopped publishing UST volumes. ${ }^{80}$ As a result, today the government publishes the text of executive agreements only as part of TIAS. ${ }^{81}$

Section I I2a was amended in I994, after the State Department had trouble publishing agreements in a timely manner. ${ }^{82}$ The amendment states that the Secretary of State is not required to publish agreements if the Secretary determines that "the public interest in such agreements is insufficient to justify their publication." ${ }^{3}$ Such a determination can be made if either the agreements are no longer in force, "the agreements do not create private rights or duties, or establish standards intended to govern government action in the treatment of private individuals," the "limited or specialized nature of the public interest in such agreements" can "adequately be satisfied by an alternative means," or "the public disclosure of the text of the agreement would, in the opinion of the President, be prejudicial to the national security of the United States." 84

The State Department implemented this amendment with a regulation that lists various categories of agreements that have been determined not to require publication. ${ }^{85}$ The Department explained that, "[d]ue to resource constraints," it "ha[d] been unable to publish agreements promptly." 86 It explained that in selecting categories for nonpublication, it had "focussed on a few areas that have a large volume of agreements that do not appear to be of general public interest or are frequently revised and readily available from private sources." ${ }^{87}$ This

\footnotetext{
79 I U.S.C. § i 2 a(a).

80 See Publication of TIAS, U.S. DEP'T OF STATE, https://2009-20I7.state.gov/s/l/ treaty/tias/pubtias/index.htm [https://perma.cc/FCA9-XG58] (noting that "funding to continue producing UST has been problematic in recent years" and that "[t]he last UST volume to be produced was Volume 35, Part 6, I983-1984").

81 See Treaties and Other International Acts Series (TIAS), supra note 3.

82 CRS TREATY STUDY, supra note I4, at 2 I I.

83 See Foreign Relations Authorization Act, Fiscal Years I994 and 1995, Pub. L. No. I03-236, $\S$ I 38, ro8 Stat. 382,397 (codified at I U.S.C. § I I 2 a).

$84 I d$.

85 See 60 Fed. Reg. 54,319, 54,320 (Oct. 23, I995) (codified as amended at 22 C.F.R. § I8I.8 (20I9)).

86 Id. at 54,3 I 9 .

87 Id.
} 
regulation was amended in 2006 and again in 2014 and now contains sixteen categories of agreements exempted from publication (primarily bilateral agreements in specified subject areas, as well as classified agreements). ${ }^{88}$

Congress amended $\S$ I 22 a again in 2004 to provide that:

The Secretary of State shall make publicly available through the Internet website of the Department of State each treaty or international agreement proposed to be published in the compilation entitled "United States Treaties and Other International Agreements" not later than I 80 days after the date on which the treaty or agreement enters into force. ${ }^{89}$

In 2006, the State Department amended its regulations to take account of this requirement. ${ }^{90}$ The statutory mandate to publish agreements on the internet, along with the lack of publication of volumes of the UST, has effectively meant that the State Department's TIAS website is the only official publication source for executive agreements. ${ }^{91}$

The Department's TIAS website currently contains international agreements dating back to I98I, but the coverage is very limited for years before $1996 .{ }^{92}$ Article II treaties and executive agreements are included on the site without differentiation. From 2006 through early 20I3, the Department maintained an additional site that contained the non-Article II agreements reported to Congress under the Case Act (described below), including a notation about whether these agreements had been reported late, but that site is no longer being updated. ${ }^{93}$

In sum, the State Department has a statutory obligation to publish international agreements, including executive agreements, subject to a variety of exceptions that are set forth in regulations promulgated by the Department. Agreements that do not fall within the exceptions must be published online within I 80 days after they enter into force. Based on materials obtained in litigation under FOIA, the Brennan Center has

88 See 22 C.F.R. § I81.8(a).

89 Intelligence Reform and Terrorism Prevention Act of 2004, Pub. L. No. I08-458, § 7 I 2 I(a), I 8 Stat. 3638,3807 (codified at I U.S.C. § I I $2 \mathrm{a}(\mathrm{d})$ ).

90 See 22 C.F.R. § I8I.9.

91 The 2004 amendment also requires the Secretary of State to submit a report to Congress each year containing an index that lists all international agreements that have been concluded and that will not be published, although this report can be submitted in classified form. See I U.S.C. $\S$ I I $2 \mathrm{~b}(\mathrm{~d})$

92 See Treaties and Other International Acts Series (TIAS), supra note 3.

93 See Reporting International Agreements to Congress Under Case Act, U.S. DEP'T OF STATE, https://2009-20I 7.state.gov/s/l/treaty/caseact/index.htm [https://perma.cc/3ERP-SC 7 P]. The State Department also published some Case Act-reported agreements, dating up until 2006, in response to a FOIA request. See Reporting International Agreements to Congress Under Case Act, U.S. DEP'T OF STATE, https://200I-2009.state.gov/m/a/ips/c24I50.htm [https://perma.cc/RT 3 J-9XNQ]. 
reported that between 2004 and 20I4, 807 binding international agreements made by the executive branch went unpublished. ${ }^{94}$ As discussed below in Part II, that number likely understates the number of agreements left unpublished by the government.

2. Reporting Requirements. - The idea of requiring that executive agreements be reported to Congress first arose in the I950s, in the context of congressional debates over the proper scope of the treaty power. In this period, Senator John Bricker of Ohio led efforts to limit the treaty power through a constitutional amendment, efforts that ultimately died out by the late I950s. ${ }^{95}$ One of the measures that was proposed as an alternative to Senator Bricker's efforts ended up being a precursor to the Case Act. From I954 through I957, Senators Homer Ferguson and William Knowland proposed bills that would have required that all executive agreements be submitted to the Senate within sixty days after being concluded, and these bills were twice approved by the Senate. ${ }^{96}$ The Senate Foreign Relations Committee noted that this legislation would serve three purposes: (I) "provid[ing] the basis for keeping the Senate duly informed on a variety of matters dealt with by executive agreements which had hitherto escaped its attention"; (2) "insur[ing] a closer degree of liaison between the Executive and Congress throughout the entire range of the treaty process"; and (3) "produc[ing] a salutary restraining effect on the conclusion of such agreements as may have been, in the past, productive of criticism, furnishing to the Senate the means whereby corrective legislative action may be taken if necessary." 97 No action was taken on the bills in the House, however, so they never became law. ${ }^{98}$

Also during this period, the State Department promulgated an internal process for determining whether to conclude agreements as Article II treaties or as executive agreements. The process, now part of the State Department's internal Foreign Affairs Manual,99 is known as "C-I 75" because it was first set forth in I955 in a Department Circular numbered I75. As the Manual notes, the C-I 75 process is designed to "facilitate[] the application of orderly and uniform measures to the negotiation, conclusion, reporting, publication, and registration of U.S.

94 Elizabeth Goitein, Brennan Ctr. for Just., The New Era of Secret Law 49 (20I6), https://www.brennancenter.org/sites/default/files/publications/The_New_Era_of_Secret_Law. pdf [https://perma.cc/3 MWE- $\left.5 \mathrm{X}_{2} \mathrm{D}\right]$. This figure includes agreements that were not published because they were classified. See id.

95 See Duane Tananbaum, The Bricker Amendment Controversy igi, 2 I4-i5 (I988).

96 See CRS TREATy STUdy, supra note $\mathrm{I} 4$, at $2 \mathrm{I} 7$ \& $\mathrm{n} .25$.

97 S. REP. No. 84-2416, at 3 (1956).

98 CRS TREATY STUDY, supra note $\mathrm{I} 4$, at $2 \mathrm{I} 7$.

99 See i I U.S. DeP'T of State, Foreign Affairs Manual $\$ 72 \mathrm{I}-727$, https:// fam.state.gov/fam/I I fam/I Ifamo720.html [https://perma.cc/6 W5 V-8YS4]. 
treaties and international agreements, and facilitate[] the maintenance of complete and accurate records on such agreements."100 According to the Manual: "An international agreement may be concluded pursuant to one or more of these constitutional bases: (I) Treaty; (2) Legislation; (3) Constitutional authority of the President."101 The Manual also sets forth various considerations that:

will be taken into account along with other relevant factors in determining whether an international agreement shall be dealt with by the United States as a treaty to be brought into force with the advice and consent of the Senate or as an agreement to be brought into force on some other constitutional basis. ${ }^{102}$

Starting in the late I960s, during the Vietnam War, Congress again became concerned about the growth of executive agreements. These concerns intensified as a result of the findings of a congressional subcommittee created in I 969 - the Symington Subcommittee on Security Agreements and Commitments Abroad - that discovered various military assistance and base agreements that had been concluded without congressional knowledge. ${ }^{103}$

Congress responded by imposing reporting requirements in the 1972 Case-Zablocki Act, also known as the Case Act. ${ }^{104}$ The Act is similar to the proposals by Senators Ferguson and Knowland in the I950s. It requires that the Secretary of State transmit to Congress the text of any international agreement other than an Article II treaty "as soon as practicable after such [an] agreement has entered into force with respect to the United States but in no event later than sixty days thereafter.”105 The Act also provides that if the President concludes that immediate public disclosure of an agreement would be prejudicial to U.S. national security, he or she does not need to transmit it to the full Congress and can instead transmit it to the Senate Foreign Relations Committee and the House Committee on International Relations under an injunction of secrecy. ${ }^{106}$

The basic problem that motivated the Case Act, as noted by Representative Zablocki, was that "Congress ha[d] not been notified or

\footnotetext{
100 Id. $\S 72 \mathrm{I}$.

101 Id. $\$ 723.2-2$.

102 Id. $\S 723 . \mathrm{I} ;$ see also id. $\$ 723.3$.

103 See Subcomm. on Sec. Agreements \& Commitments AbroAd, 9ist Cong., SECURity AGREements AND COMmitments ABROAD (Comm. Print ig7o); see also ARthur M. SCHLesinger, JR., The IMPERIAL PRESIDENCY 20I-o6 (Mariner Books 2004) (I973).

104 See Pub. L. No. 92-403, 86 Stat. 6r9, 6r9 (I972) (codified as amended at I U.S.C. § I I 2 b).

105 Id. Shortly before the adoption of the Act, Congress considered proposals that would have required all international agreements other than Article II treaties to be transmitted at least sixty days before they took effect, but these proposals were not adopted. See CRS TREATY STUDY, supra note $\mathrm{I} 4$, at $2 \mathrm{I} 6$.

106 See I U.S.C. $\S$ I I 2 b(a).
} 
fully informed about international agreements entered into by the President or other officials of the executive branch." ${ }^{107}$ The Act did not aim to regulate the permissible scope of executive agreements. But it did aim to facilitate Congress's substantive review of executive agreements through greater transparency. When testifying in support of the Act, Senator Case noted, for example, that "to have knowledge of and copies of all agreements would make it possible for us to decide whether or not particular agreements should come before us as treaties. We can deal with that question, and we do not estop ourselves by getting copies of the agreements."108

In I98I, pursuant to a directive in a 1978 amendment to the Case Act, the State Department adopted regulations implementing both the Act and the publication statute discussed above. ${ }^{109}$ Among other things, the regulations provide that the Department will transmit to Congress a background statement to accompany each agreement reported under the Act, and that this background statement will include "a precise citation of legal authority." 110 These background statements are not mandated by the Case Act, however, and the regulations do not require their disclosure to the public. ${ }^{11}$ Prior to our FOIA litigation, these background statements, which we refer to as "cover memos," had rarely been seen outside of the government.

The regulations also exclude various materials from what the Department considers to be "international agreements" for purposes of both its publication and reporting obligations. ${ }^{112}$ For example, the regulations state that "[d]ocuments intended to have political or moral weight, but not intended to be legally binding, are not international agreements." 113 (We will return to the special issues presented by nonbinding agreements below in section III.A.3.) In addition, implementing agreements that "are closely anticipated and identified in the underlying agreement" are not treated by the Department as separate international

107 I 8 CONG. REC. 28,085 (i972) (statement of Rep. Zablocki).

108 Id. at 4092 (statement of Sen. Case); see also S. ReP. NO. 92-591, at 5 (I972) ("The present proposal, which was originally initiated as a modest alternative to the Bricker amendment, does not purport to resolve the underlying constitutional question of the Senate's treaty power. It may well be interpreted, however, as an invitation to further consideration of this critical constitutional issue."); CRS TREATY STUDY, supra note I4, at 23 ("A basic concern of the Senate has been whether an executive agreement is properly within the authority of a treaty or statute.").

109 See 22 C.F.R. § I8I.I-.9 (20I9); see also I U.S.C. § I I 2 b(f).

11022 C.F.R. § I8I.7(c). The State Department apparently had voluntarily been providing this information to Congress for classified agreements since 1973. See CRS TREATy STUDy, supra note 14, at 23,228 .

111 See Ryan Harrington, Understanding the "Other" International Agreements, I08 LAW LIBR. J. 343, 352 (2016) ("Critically, the Case Act does not require the Executive to publish the authority for the agreement.").

11222 C.F.R. $§$ I 8 I.2(a).

$113 I d . \S \mathrm{I} 8 \mathrm{I} .2(\mathrm{a})(\mathrm{I})$. 
agreements for purposes of publication and reporting. ${ }^{114}$ Nor, according to the regulations, do international agreements for these purposes include "[m]inor or trivial undertakings, even if couched in legal language and form." 115 This latter limitation is presumably narrower than the sixteen categories of agreements currently exempted by regulation from publication. Indeed, the publication obligation was already subject to this "minor or trivial" limitation when the Department started adding the specific exemptions. Importantly, the specific exemptions apply only to the Department's publication obligation, not its obligation to report to Congress. ${ }^{116}$

In sum, the Case Act requires the State Department to report to Congress all non-Article II international agreements within sixty days after they enter into force, subject to limitations relating to secret agreements. This reporting obligation, even with the restrictions on what the State Department considers to be "international agreements," is significantly broader than the Department's publication obligation, described above in section I.B.I. In addition, pursuant to regulation, the State Department must provide Congress with a "precise citation of legal authority" for each non-Article II agreement, but these citations are not made available to the public.

3. Periodic Congressional Concerns and Amendments. - As discussed, the transparency regime for executive agreements consists of bifurcated requirements of publication and reporting. These requirements are bifurcated because the publication requirements substantially predate the Case Act, serve a different purpose, have a longer transparency delay, and eventually developed a carve-out for relatively unimportant agreements because publication (in hard copy) was thought to take substantially more resources than reporting to Congress.

Congress has often expressed concerns about how well the transparency regime is working. ${ }^{117}$ These concerns have related in particular to late reporting and underreporting of agreements by the State Department. ${ }^{118}$ One reason that has often been cited by the Department for such deficiencies is that it does not always receive timely notice of agreements from other departments and agencies within the executive branch. ${ }^{119}$ These departments and agencies are generally supposed to

\footnotetext{
$114 I d . \S$ I 8 I.2(c).

$115 I d . \S$ I $8 \mathrm{I} .2(\mathrm{a})(2)$

116 Id. § г 8 I.8(a).

117 See generally CRS TREATy STUDY, supra note I4, at 2 I8-33 (describing various problems with reporting under the Case Act and congressional efforts to address them).

118 See id.

119 See id. at 230.
} 
coordinate with the State Department prior to negotiating agreements, ${ }^{120}$ but it can be difficult for State to monitor the subsequent conclusion of these agreements. A related issue is that agencies do not always understand which agreements are covered by the Case Act. ${ }^{121}$

In 1977, Congress attempted to address this coordination problem by amending the Case Act to provide that "[a]ny department or agency of the United States Government which enters into any international agreement on behalf of the United States shall transmit to the Department of State the text of such agreement not later than twenty days after such agreement has been signed." 122 In an effort to further reduce incomplete and late reporting, Congress amended the Act in 1978 to require that agreements concluded orally had to be reduced to writing and reported within the sixty-day window. ${ }^{123}$ A report from the Senate Foreign Relations Committee discussing this change explained that it was designed to "eliminate any possible incentive for entering into certain agreements orally rather than in writing" and to "require the transmission of intelligence-sharing and intelligence liaison agreements, many of which are oral." 124

The 1978 amendments also required the President to give Congress a report every year on any agreements submitted late, "describing fully and completely the reasons for the late transmittal." ${ }^{25}$ The Senate Foreign Relations Committee noted that "[l]ate transmittals ha[d] been a continuing problem. Roughly one-third of all agreements transmitted [the previous] year were transmitted late, and nearly a fourth of those late transmittals were over a year late." 126 This presidential reporting requirement was eliminated, however, effective as of May I5, 2000, pursuant to a general sunset provision enacted in late I995 that phased out a variety of executive branch reporting requirements. ${ }^{127}$

The "late transmittal" reports from I 978 to 2000 have not generally been made public, and we were able to find only two of them - the one

120 See 22 C.F.R. § I8I.4(a).

121 See CRS TREATY STUDY, supra note I4, at 230-32.

122 Act of June 15 , I977, Pub. L. No. 95-45, §5(a), 9I Stat. 22 I, 224 (codified at I U.S.C. $\S$ II $2 \mathrm{~b}(\mathrm{a})$ ); see S. COMM. ON FOREIGN RELS., 95TH CONG., MARK-UP: LEgislation DEALING WITH INTERNATIONAL FINANCIAL INSTITUTIONS, DEVELOPMENT ASSISTANCE and the State Department Supplemental Authorization ReQuest i4-I5 (i977) (statement of Sen. Case).

123 Foreign Relations Authorization Act, Fiscal Year 1979, Pub. L. No. 95-426, § 708, 92 Stat. 963, 993 (I978) (codified as amended at I U.S.C. § I I 2 b(a)); see S. ReP. No. 95-842, at 45 (I978).

124 S. REP. NO. $95-842$, at 45.

$125 \S 708,92$ Stat. at 993 (codified as amended at I U.S.C. § I I 2 b(b)).

126 S. REP. NO. $95-842$, at 46.

127 See Federal Reports Elimination and Sunset Act of 1995, Pub. L. No. 104-66, § 3003, I09 Stat. 707, 734 (codified at 3I U.S.C. § I I I3 note). 
for calendar year $1978^{128}$ and the one for calendar year I98I. ${ }^{129}$ In the report covering 1978, the State Department reported, on behalf of the President, that $\mathrm{I}_{32}$ of 520 international agreements - that is, about twenty-five percent - had been transmitted late to Congress under the Case Act. ${ }^{130}$ In the report for I98I, President Reagan reported that 99 of 368 international agreements - that is, about twenty-seven percent - had been reported to Congress late. ${ }^{131}$ Both reports indicated that in many cases the agreements were reported late because the State Department had not received them in a timely manner from other executive agencies and departments. ${ }^{132}$

In 1987, Congress sought to improve compliance with the Case Act by providing that no funds would be available to implement any agreement not transmitted within sixty days until the text of the agreement had been transmitted. ${ }^{133}$ The report from the Senate Foreign Relations Committee on the legislation containing this provision explained that, "during I986, 65 Executive Agreements were transmitted after the 60day period had expired," and that the funding restriction was "intended to enforce compliance with the Case-Zablocki Act."134 However, due to a limitation added when the House and Senate versions of the legislation were reconciled, the funding restriction applied for only two years. ${ }^{135}$

Late reporting of agreements to Congress continued to be a concern after these amendments. In a $200 \mathrm{I}$ study, the Congressional Research Service presented detailed statistics on late reporting between 1978 and I999. During this period, sometimes more than twenty-five percent of agreements were reported late in a given year. ${ }^{136}$ The Congressional Research Service reported that untimely reporting was "still a source of concern although the numbers [were] notably lower in recent years than in earlier periods," pointing out that "[b]etween I 993 and I999, the percent[age] of late to total transmittals fell to I3.5 percent."137 (As discussed below in section II.B.I.b, this improvement did not last, and untimely reporting increased sharply in the years after the Congressional Research Service study.)

\footnotetext{
128 See 96Th Cong., Reports Submitted to CONGRess Pursuant to the Foreign Relations Authorization ACt, Fiscal Year i979 (Public LaW 95-426), at I34-47 (J. Comm. Print i 979) [hereinafter i 978 LATE TRANSMitTal REPORT].

129 See H.R. DoC. NO. 97-I 48 (I982); CRS TREATy STUDY, supra note I4, at 223.

130 I978 LATE TRANSMITTAL REPORT, supra note I 28 , at I 34 .

131 H.R. DOC. NO. 97-I48, at 3.

132 Id.; I978 LATE TRANSMITTAL REPORT, supra note I 28 , at I40.

133 Foreign Relations Authorization Act, Fiscal Years I 988 and I989, Pub. L. No. I00-204, § I39, Ior Stat. I33I, I347 (I987) (codified as amended at i U.S.C. § I I 2 b note).

134 S. REP. No. Ioo-75, at 40 (1987).

135 \& I39(b), I0r Stat. at I 347 .

136 CRS TREATY STUDY, supra note I4, at 226 tbl.X-I.

137 Id. at 228.
} 
Additional controversy concerning late reporting and nonreporting of agreements arose in 2004 when "the House Committee on International Relations learned that, due to numerous management failures within the Department of State, over 600 classified and unclassified international agreements dating back to I 997 . . had not been transmitted to Congress." 138 In response, Congress amended both the Case Act and the publication statute described above in section I.B.I. As previously noted, the amendments required the Secretary of State to publish international agreements on the Department's website not later than I 80 days after they entered into force. ${ }^{139}$ In addition, the amendments required the Secretary of State to submit an annual report to Congress containing an index of all signed or proclaimed international agreements made that year that were not published in the TIAS compilation, which the Department was allowed to submit in classified form. ${ }^{140}$ They also revived the funding restriction from the I980s for three years (20052007), thus withholding funding to implement any agreement that the executive branch did not transmit to Congress within sixty days. ${ }^{141}$

Members of Congress have continued to worry about agencies not reporting their agreements to the State Department in a timely manner, which in turn causes the Department to be late in its reporting under the Case Act. In 20I7, Senator Bob Corker, then Chairman of the Senate Foreign Relations Committee, proposed an amendment to the Case Act that would have required "[e]ach department or agency of the United States Government that enters into any international agreement" to "designate a Chief International Agreements Officer" who would "have department- or agency-wide responsibility for efficient and appropriate compliance with [the obligation] to transmit the text of any international agreement to the Department of State not later than 20 days after such agreement has been signed."142 But this proposed amendment to the Case Act was not enacted. ${ }^{143}$

The tables below show, first, a chronology of the most important amendments to the publication and reporting statutes (Table I), and, second, a comparison of the current publication and reporting obligations (Table 2).

\footnotetext{
138 I50 CONG. REC. 25,704 (2004).

139 I U.S.C. $\S$ I $22 \mathrm{a}(\mathrm{d})$.

140 Id. $\S$ I I $2 \mathrm{~b}(\mathrm{~d})$.

141 Id. $\S$ I I 2 b note (reinstating limitation for fiscal years 2005, 2006, and 2007).

142 S. I63I, I I5th Cong. $\$ 802$ (as reported by S. Comm. on Foreign Rels., Sept. 6, 201 7 ).

143 This proposed amendment to the Case Act was included in a subsequent bill — the Department of State Authorization Act of 2019. See H.R. 3352, I I6th Cong. § 901 (2019).
} 
Table I: Important Amendments to the Publication and Reporting Statutes

\begin{tabular}{|c|c|}
\hline 1977 & $\begin{array}{c}\text { Reporting statute amended to require agencies } \\
\text { and departments to transmit agreements to } \\
\text { the State Department within twenty days after } \\
\text { the agreements are signed. }\end{array}$ \\
\hline $\mathrm{I978}$ & $\begin{array}{c}\text { Reporting statute amended to require the President } \\
\text { to give a yearly report to Congress about agreements } \\
\text { submitted late; this amendment was later subjected } \\
\text { to a sunset provision and has not been operative } \\
\text { since } 2000 .\end{array}$ \\
\hline $\mathrm{I} 987$ & $\begin{array}{c}\text { Reporting statute amended to impose funding re- } \\
\text { striction on implementing agreements reported late; } \\
\text { this amendment lasted two years (I988-1989). }\end{array}$ \\
\hline $\mathrm{I} 994$ & $\begin{array}{c}\text { Publication statute amended to allow exemption } \\
\text { for agreements where there is insufficient public } \\
\text { interest to warrant publication; regulations } \\
\text { currently list sixteen categories of agreements } \\
\text { not requiring publication. }\end{array}$ \\
\hline 2004 & $\begin{array}{c}\text { Publication statute amended to require online } \\
\text { publication within I80 days of agreement } \\
\text { entering into force. }\end{array}$ \\
& $\begin{array}{c}\text { Reporting statute amended to impose funding re- } \\
\text { striction on implementing agreements reported late; } \\
\text { this amendment lasted three years (2005-2007). }\end{array}$ \\
\hline
\end{tabular}


Table 2: Comparison of Publication and Reporting Requirements

\begin{tabular}{|c|c|c|}
\hline & Publication & Reporting \\
\hline $\begin{array}{c}\text { Scope of } \\
\text { obligation }\end{array}$ & $\begin{array}{c}\text { All non-Article II agree- } \\
\text { ments, except those for } \\
\text { which there is insuffi- } \\
\text { cient public interest } \\
\text { (now including sixteen } \\
\text { categories of agreements } \\
\text { pursuant to regulation). }\end{array}$ & $\begin{array}{c}\text { All non-Article II } \\
\text { agreements, with a } \\
\text { special process for } \\
\text { reporting secret } \\
\text { agreements. }\end{array}$ \\
\hline $\begin{array}{c}\text { Non-Article II } \\
\text { agreements spe- } \\
\text { cifically identi- } \\
\text { fied? }\end{array}$ & $\begin{array}{c}\text { Article II and non- } \\
\text { Article II agreements } \\
\text { published together with- } \\
\text { out distinction. }\end{array}$ & $\begin{array}{c}\text { Only non-Article II } \\
\text { agreements are } \\
\text { included. }\end{array}$ \\
\hline $\begin{array}{c}\text { Legal authority } \\
\text { specified? }\end{array}$ & $\begin{array}{c}\text { No citation of legal } \\
\text { authority given. }\end{array}$ & $\begin{array}{c}\text { Citation of legal au- } \\
\text { thority given to } \\
\text { Congress pursuant to } \\
\text { regulation but not to } \\
\text { public. }\end{array}$ \\
\hline Timing & $\begin{array}{c}\text { Within I80 days after } \\
\text { entering into force. }\end{array}$ & $\begin{array}{c}\text { Within sixty days } \\
\text { after entering } \\
\text { into force. }\end{array}$ \\
\hline
\end{tabular}

4. Other Transparency Requirements. - We have described above only the generally applicable transparency regime for executive agreements. Congress has also sometimes imposed additional and more targeted transparency requirements. Most notably, in a number of instances it has required reporting of particular types of agreements before they take effect. ${ }^{144}$ For example, Congress has long specified that international fishery agreements shall not become effective "before the close of the first I 20 days (excluding any days in a period for which the Congress is adjourned sine die) after the date on which the President transmits to the House of Representatives and to the Senate a document setting forth the text" of the agreement. ${ }^{145}$ Similarly, it has long required that nuclear cooperation agreements be submitted to Congress for ex ante review. ${ }^{146}$

\footnotetext{
144 See CRS Treaty StUdy, supra note I4, at 235-38, 236 tbl.X-3; Robert E. Dalton, United States, in National Treaty LaW AND PRACTICE 765, 770-7 I (Duncan B. Hollis, Merritt R. Blakeslee \& L. Benjamin Ederington eds., 2005).

145 I6 U.S.C. § I82 3(a). The Congressional Research Service published a table containing a noncomprehensive list of statutory reporting requirements relating to various types of agreements, most of which require ex ante reporting. See CRS TREATy StUdy, supra note I4, at 236 tbl.X-3.

146 See 42 U.S.C. § 2 I 53(d).
} 
More recently, the Bipartisan Congressional Trade Priorities and Accountability Act of $2015^{147}$ requires presidential reporting of an intention to conclude an agreement concerning tariff barriers. ${ }^{148}$ In other instances, Congress has not regulated the transparency of executive agreements directly but has instead imposed reporting duties relating to executive branch programs that are often the subject of executive agreements. ${ }^{149}$ For example, many ex ante congressional-executive agreements are based on the Foreign Assistance Act of i96r. ${ }^{150}$ Congress has long imposed a variety of reporting obligations in connection with the executive branch's foreign aid programs, and recently it enacted the Foreign Aid Transparency and Accountability Act of 20I6, ${ }^{151}$ which imposes new publication and reporting duties. ${ }^{152}$

$* * *$

In sum, Congress has relied primarily on transparency directives to regulate executive agreements. Rather than insist on approving each individual agreement that the executive branch has concluded, Congress has contented itself with requiring that the executive branch keep it and, to a lesser degree, the public - informed about the binding international legal commitments concluded on behalf of the United States. Particularly after the Supreme Court's I 983 decision in INS v. Chadha, which eliminated Congress's ability to have a legislative veto check on agreements, transparency became the principal tool that Congress used to ensure that the executive branch was not overstepping the bounds of delegated authority. ${ }^{153}$ We now turn to examine how that transparency regime has worked in practice.

\section{DOES THE TRANSPARENCY REGIME WORK? AN EMPIRICAL ASSESSMENT}

How well is the transparency regime for executive agreements described in Part I working? How well does the executive branch meet its legal obligations to keep Congress and the public informed? And

147 I9 U.S.C. $\$ \$ 420 \mathrm{I}-42$ IO.

148 See id. $\S 4202(\mathrm{a})(2)$. For a report by President Trump submitted pursuant to this provision, see Message to the Congress on Notification of Initiation of the United States-Japan Trade Agreement, 20 I 9 DAILY COMP. PRES. DOC. I (Sept. I6, 20I9).

149 See CRS TREATY STUDY, supra note I4, at 238-39.

150 Pub. L. No. 87-I 95, 75 Stat. 424 (codified as amended in scattered sections of 22 U.S.C.); see Hathaway, supra note 8, at I56-57.

151 Pub. L. No. I I4-I9I, I30 Stat. 666 (codified at 22 U.S.C. \$§ 2 I5 I note, 2394 c).

152 See 22 U.S.C. $\$ 2394$ c. For a report to Congress on the implementation of the Act, see OFF. of MgMt. \& Budget, OMB REPORT TO CONGRESS ON THE IMPLEMENTATION OF THE FOREIGN AID TRANSPARENCY AND ACCOUNTABILITY ACT (FATAA) (20I9), https://www.whitehouse.gov/wp-content/uploads/20I9/03/FataaOmbReport_Master_Final.pdf [https://perma.cc/M2LH-L 7 CL].

153 See supra pp. 633-34. 
how well does the executive branch adhere to the limits on its constitutional and statutory authority to conclude executive agreements?

To answer these questions, we sought and eventually obtained under FOIA thousands of the cover memos that the State Department has sent to Congress during the last several decades when reporting executive agreements under the Case Act. With the assistance of a team of students, we spent almost two years coding and analyzing the memos. To help put this information in context, we also conducted interviews with executive branch and congressional participants in the process. The combination of qualitative and quantitative material provided us with novel findings regarding the transparency regime for executive agreements.

This Part begins by describing the qualitative evidence: How are agreements actually made, and what is the internal process for complying with the statutory requirements? It then describes the results of our analysis of the more than 5,000 cover memos that we received from the State Department. These memos have rarely been seen by anyone outside the U.S. government, and they have never been made public on anything approaching this scale. Analyzing them, and the legal bases they cite for the agreements to which they are attached, reveals a great deal about how the executive branch uses its delegated authority. Finally, this Part uses these data to gain some insight - and raise new questions - about how well the executive branch keeps Congress and the American public informed about the binding international agreements that it concludes almost daily.

\section{A. Qualitative Evidence: How Executive Agreements Are Made and Reported to Congress}

To understand the context in which the State Department sends the cover memos to Congress under the Case Act, it is important to have some understanding of the internal executive branch process for making executive agreements. Unfortunately, there is no public account of this process. To get some sense of it, we interviewed more than a dozen current and former government attorneys. ${ }^{154}$ They spoke with us about their experiences working on the process of negotiating and concluding executive agreements for the United States, or - in the case of attorneys

154 The description in this section is based on a series of interviews and discussions with past and present lawyers from the State Department Legal Adviser's Office, the House Foreign Affairs Committee, and the Senate Foreign Relations Committee. Unless they are specifically quoted, individual interviews are not cited. Hathaway applied for and received an exemption determination from the Yale Human Research Protection Program Institutional Review Board (IRB Protocol ID 2000025 293). Letter from the Hum. Rsch. Prot. Prog. Institutional Rev. Bds., Yale Univ., to Oona Hathaway I (May 6, 20I9) (on file with the Harvard Law School Library). The research was deemed exempt under 45 C.F.R. $§ 46$. I04(2)(ii). Letter from the Hum. Rsch. Prot. Prog. Institutional Rev. Bds. to Oona Hathaway, supra, at I. All interviews are anonymous. 
who worked for Congress - receiving the reports provided by the executive branch regarding the agreements concluded. Although the three authors of this piece have each studied executive agreements for more than a decade and have worked in the executive branch on international law issues, much of what we learned from these conversations came as a surprise.

How does the process work? Let us begin with a hypothetical agreement - say an agreement to engage in scientific and technological cooperation with Kazakhstan. ${ }^{155}$ The U.S. Geological Survey of the Department of the Interior might want to collect information about the mineral resources of Kazakhstan. Its officials would reach out to their counterparts in the State Department's Bureau of Oceans and International Environmental and Scientific Affairs (OES) about how best to proceed, and a person in that office may suggest that it would be easier to conduct that work if there were an international agreement between the U.S. Department of the Interior and the corresponding department in Kazakhstan. Someone in OES would then likely reach out to a State Department lawyer in the Office of the Assistant Legal Adviser for Oceans, Environment, and Science (L/OES) to seek advice about how to proceed. ${ }^{156}$ While there is an office in the Legal Adviser's Office, Treaty Affairs (L/T), tasked with managing international agreements, these lawyers generally do not get involved until later in the process. L/T may be involved earlier, however, "when things are thorny."157

Before negotiation of the agreement may begin, the State Department's Foreign Affairs Manual requires a "C-I 75 authorization." As discussed in Part I, the Circular I 75 (or "C-I 75") procedure lays out the steps that the executive branch must take to negotiate, conclude, report, publish, and register U.S. treaties and international agreements. ${ }^{158}$ One of the objectives of this process is to ensure "[t]hat the making of treaties and other international agreements for the United States is carried out within constitutional and other appropriate limits." 159 The request for C-I 75 authorization will generally be drafted by the State Department policy bureau seeking the agreement (here OES).

155 This is not, in fact, entirely hypothetical. This agreement exists, having been concluded in 2014. See Memorandum of Understanding Concerning Scientific and Technical Cooperation in the Earth Sciences, Kaz.-U.S., at I, June 6-I6, 2014, T.I.A.S. No. I4-6I6.

156 The Legal Adviser's Office of the State Department is organized to mirror the policy offices in the Department. Generally speaking, for each major policy office, there is an office within the Legal Adviser's Office that supports it. For a list of the regional and functional offices within the State Department Legal Adviser's Office, see Other Legal Adviser Offices, U.S. DEP'T OF STATE, https://www.state.gov/Other-Legal-Adviser-Offices [https://perma.cc/DEW8-5DAW].

157 Interview by Oona Hathaway with Former U.S. Government Lawyer (June 4, 20I9).

158 The State Department's Foreign Affairs Manual requires that the Secretary of State or a designee give advance authorization for negotiation of an agreement as well as signature of the final text. See i I U.S. DeP'T OF STATE, supra note 99 , $\$ \$ 72$ I-727.

159 Id. $\S 722(\mathrm{I})$. 
The lawyer in the relevant section of the Legal Adviser's Office (here L/OES) will then prepare a separate memorandum of law to attach to the $\mathrm{C}$-I 75 request. This memorandum of law will address the legal basis for the proposed action - and whether the agreement contemplated can be concluded without additional congressional action (either approval by two-thirds of the Senate as an Article II treaty or approval via ordinary legislation as an ex post congressional-executive agreement). ${ }^{160}$

If the person preparing the request (here the person in OES) knows a great deal about what the ultimate agreement will contain, then the request will detail the content of the intended agreement and seek approval for both negotiation and authority to conclude at the same time. (In the ordinary course, there must be separate C-I75 requests - one for negotiation and, after negotiation is completed or nearly completed, another for authority to conclude.) In some instances, the request may seek approval to negotiate or conclude a series of related agreements for example, it might request approval to negotiate a number of similar agreements on scientific and technological cooperation with a series of countries. Although there is a general template for $\mathrm{C}-\mathrm{I} 75$ memos, the level of detail provided in the memos varies a great deal across offices and over time. Individual offices within the Legal Adviser's Office may require more detailed information about the agreements and the legal authority to conclude them than do others. This is largely an artifact of differing office cultures and practices.

Sometimes if an agreement is novel in some important way, the lawyer in L/OES will work with a lawyer in $\mathrm{L} / \mathrm{T}$ to reach out to lawyers in the Senate Foreign Relations Committee to discuss the agreement. The State Department lawyer will explain the proposed agreement and ask if the staff has any particular concerns. (Similar conversations may happen with House staff, but the interviewees did not mention them.) The degree to which such informal consultations take place has varied over time. It depends on the relationships between the people in the offices involved and how comfortable they are "picking up the phone" to talk to their counterpart. ${ }^{161}$ Informal outreach from State to Congress is unlikely, for example, concerning an agreement that has similarities with another one recently concluded and reported. The $\mathrm{C}-\mathrm{I} 75$ request would likely be shorter in this circumstance as well. As one former Legal Adviser's Office attorney put it: "These things accrete over time. Maybe for the first science and technology agreement with Kazakhstan the

160 In some cases, the memorandum of law is not a separate, attached memorandum but is included as a section of the memo seeking C-I 75 authorization.

161 In the past, the Legal Adviser's Office at the State Department has loaned lawyers to the Senate Foreign Relations Committee, creating a bridge between the Committee and the State Department. 
memorandum of law would be longer. The eighteenth science and technology agreement would be pro forma. There could be dozens and dozens of similar agreements."162

When ready, the C-I 75 request is sent to a policy official designated by the Secretary of State, such as the Deputy Secretary or the Under Secretary for Political Affairs, or to lower-level officials designated, in turn, by them. For science and technology agreements such as our hypothetical agreement with Kazakhstan, for example, approval authority is delegated to the Assistant Secretary for the Bureau of Oceans and International Environmental and Scientific Affairs. The entire package must also be approved by the Legal Adviser's Office. In the Legal Adviser's Office, normally, both L/T and the substantive office (here L/OES) must sign off on the request. In the case of requests raising more significant issues or relating to more significant agreements, the Deputy Legal Adviser or Legal Adviser (the "front office" or "L/FO") will also be asked to approve. No agreement can be concluded without the approval of both the State Department's policy office and the Office of the Legal Adviser. Thus, the C-I 75 process serves a centralizing role for executive agreements concluded by the U.S. government.

Once the U.S. Geological Survey of the Department of the Interior has finished negotiating the executive agreement, OES and L/OES must prepare a second $\mathrm{C}-\mathrm{I} 75$ request before the agreement may be signed and concluded (unless the first request folded together negotiation and conclusion). The same process applies. Once the Assistant Secretary for the Bureau of Oceans and International Environmental and Scientific Affairs, L/OES, and L/T have all signed off, the agreement may be signed and concluded. At this point, $\mathrm{L} / \mathrm{T}$ is supposed to report the agreement to Congress within sixty days after it enters into force. ${ }^{163}$ As our data below will make clear, that does not always happen. The most common reason why is that the agencies and departments that usually negotiate the agreements do not always report the agreements back to State in time to meet the Case Act deadline. In addition, $\mathrm{L} / \mathrm{T}$ is often busy and understaffed and has not always prioritized timely Case Act reporting. As one former attorney in the office explained: "We were doing hundreds of these a year; it was overwhelming how many were coming in." 164

The Case Act reports to the congressional committees contain the agreement and a cover memo. That cover memo includes a title, the date the agreement was concluded, a brief explanation of the agreement, and a section entitled "Legal Authority." This last section is usually very brief, normally containing a citation or string of citations to some combination of statutes, the U.S. Constitution, prior treaties, and other

\footnotetext{
162 Interview by Oona Hathaway with Former U.S. Government Lawyer, supra note ${ }_{5} 57$.

163 There are a few exceptions. See supra section I.B.4, pp. 656-57.

164 Interview by Oona Hathaway with Former U.S. Government Lawyer, supra note ${ }_{5} 7$.
} 
authorities. Though the level of detail varies across cover memos, they are always limited to a single page. We include an example in Appendix B.

Importantly, these cover memos are not prepared by lawyers. Instead, they are prepared by treaty analysts in L/T. The analysts draw the information contained in the cover memo from the agreement and from the C-I 75 request. They are assigned to work with particular offices (for example, OES and L/OES will work with the same treaty analyst on all their executive agreements), and they continue with those assignments in some cases for decades. Treaty analysts develop relationships not only with the personnel in offices inside the State Department but also within the agencies with which those offices regularly work. As one former Legal Adviser's Office attorney explained, the treaty analysts play a key role in the process:

The treaty analysts would check the texts for grammar, they would get the ribbons and pens, keep the treaties in the treaty vault. They kept the travaux, subsequent practice, and interpretations in a file. They kept the files, they did depository functions, and they would often be the technical advisers to L lawyers. They were the institutional memory. There was one analyst who had been in the office since r972, and she would get a call about, say, a basing agreement they wanted to conclude, and she would say, "I saw something similar in I978." They would also sometimes serve as a point of contact with the agencies: Treasury, Defense, etc. They would often be the one saying we need to get a $\mathrm{C}-\mathrm{I} 75$ because an agreement was getting prepared in another agency. ${ }^{165}$

As a result of the robust role of treaty analysts, the approach to the cover memos may reflect different practices not only of the different offices (L/OES vs. Office of Political-Military Affairs (L/PM)) but also of individual treaty analysts. Before 2014 , the memos were rarely reviewed by lawyers in L/T or the other lawyers in the Legal Adviser's Office. (We are told that this changed in 20I4 and that lawyers now regularly review the cover memos.) The limited involvement of lawyers in preparing the memos before 2014 probably explains some of the odd citations we found in them. For example, the memos frequently cite the State Department's general authority to negotiate even though that authority is legally irrelevant to the authority to conclude the agreement.

More than one former lawyer in the office cautioned that these cover memos may not reflect the considered legal judgment of the lawyers, because they were until recently prepared by the analysts alone and because they are prepared without any intent to make them public. Notably, one lawyer who had written a number of international agreements during a multidecade career in the office had not even seen a cover memo for most of that time and was unaware until seeing one that the memo contains a summary of legal authorities for the agreement. Even 
though lawyers were not directly involved in preparation of the cover memos before 20I4, the legal citations they contain are likely based on the underlying $\mathrm{C}$-I 75 legal memos that are prepared by lawyers. Moreover, whatever the process for generating them, the memos contain the executive branch's response to the regulatory obligation to inform Congress of the legal authority on which it relies in concluding reported executive agreements.

A number of practices related to the cover memos likely emerged as a result of limited staff and resources. At one point in the early 2000 , for example, L/T had only two attorneys. That thin staffing meant that the attorneys could not meaningfully oversee every proposed executive agreement. Record keeping has not always been careful, again because it was not a priority and resources were limited. That led to significant reliance on the institutional memory provided by treaty analysts. It was only in the Obama Administration that the office finally hired an archivist to properly store and manage the treaty collection that had been held in a makeshift "treaty vault" containing definitive legal copies of some of the country's most important and historic treaties, some with presidential signatures dating back to the early years of the country. At one point, an attorney in the office discovered that, contrary to what is required by the Case Act, ${ }^{166}$ classified agreements had not been reported to Congress for at least a couple of years. The general consensus of those interviewed was that late and otherwise incomplete reporting to Congress was not an intentional act by the State Department staff, but rather was the result of oversight by an office that did not have enough attorneys to properly manage the workload.

Finally, the interviews revealed interesting information about the Office of the Legal Adviser's views about the nature and scope of the President's legal authority to enter into agreements. As noted above, the "legal authority" sections of the cover memos are cursory and before 2014 were usually not written or reviewed by State Department lawyers. The interviews made clear that the opacity goes even deeper, since the Office of the Legal Adviser itself lacked a consistent view about the degree of authority needed to authorize the conclusion of an agreement. Two basic views - both very favorable to presidential authority emerged from the interviews.

One view is that the President can make a binding international agreement on any topic, without authorization from Congress, so long as the President has authority to regulate the matter under domestic law and the agreement is consistent with domestic law. This view is akin to

166 See I U.S.C. § I I 2 b(a); 22 C.F.R. § I8 I.7(b) (2019) ("Classified agreements shall be transmitted by the Assistant Legal Adviser for Treaty Affairs to the Senate Committee on Foreign Relations and to the House Committee on International Relations."). 
the Executive Agreements+ view described by Professors Bodansky and Spiro. ${ }^{167}$ A second and more modest view is that, although mere consistency with domestic law is not enough by itself, there is authority to make an agreement if Congress has authorized international cooperation on the topic, something more readily inferred when the Executive has engaged in similar practices in the past in which Congress has acquiesced. ${ }^{168}$ Those who take this latter view note that when a new type of executive agreement that relies on something less than express authorization from Congress is proposed, the lawyer working on the agreement in the Office of the Legal Adviser might reach out to his or her counterpart in the Senate Foreign Relations Committee to discuss it and ensure that it does not raise any concerns. Such informal interaction has not been consistent, however, and several interviewees reported that it broke down during the Trump Administration. One interviewee stated that "[t]he message from the top [of the Administration] is resist, defy, don't respond," 169 and that this attitude has led to growing mutual distrust.

The interviews also made clear, relatedly, that the State Department does not draw a sharp distinction between agreements concluded under the President's own constitutional authority (what scholars refer to as sole executive agreements) and agreements concluded on the basis of congressional authority granted to the President (what scholars refer to as ex ante congressional-executive agreements). The $\mathrm{C}-\mathrm{I} 75$ request process is the same for both, and they are reported to Congress together, without any formal distinction made between them. ${ }^{170}$ The only way in theory to tell them apart is to examine the legal authorities cited in the cover memo - information that is not generally made public and that, as we shall see, often does not permit one to infer the type of agreement with any confidence. As we explain further in section III.B. I, the failure to clearly distinguish between the two categories of agreements in the course of negotiating, concluding, and reporting them may partially explain some of what might appear to be carelessness in identifying the legal basis for an international agreement.

Once the Case Act reports are ready for transmittal to Congress, they are printed out and delivered via courier to the House Foreign Affairs Committee and Senate Foreign Relations Committee. Upon receipt,

167 See supra p. 643.

168 One interviewee referred to this theory of executive power as a "three-legged stool," where the three legs are (I) consistency with domestic law, (2) some indication from Congress that it favors global cooperation, and (3) consistent past practice in which Congress has acquiesced. Interview by Oona Hathaway with Former U.S. Government Lawyer (Aug. 29, 20I9).

169 Interview by Oona Hathaway with Former U.S. Government Lawyer (July 23, 20I9).

170 The Department's internal legal memorandum included with the C-I 75 request would, however, assess whether the agreement could be concluded without further congressional action whether because the agreement rested on the President's constitutional authority, existing statutory authority, a prior treaty, or some combination of these sources. 
each committee scans the unclassified reports and circulates the electronic versions to the appropriate staff members. Classified reports are sent to a Sensitive Compartmented Information Facility, and attorneys from the committees have to make special arrangements to view them.

All those who had reviewed the Case Act reports as congressional staffers agreed that there was no time to carefully review them. None had researched the legal authority cited in a cover memo to confirm that it in fact supported the agreement. There are only a small handful of lawyers in both committees to handle a huge range of topics, and they do not have time to conduct that level of oversight. As one former congressional staff member put it: "It's not a lack of engagement; we just have to choose what we will work on."171 Another echoed the importance of those outside government raising the alarm about problematic agreements: "Our scarcest resource is time. To do our jobs, we have to leverage everyone out there in the think tank and public advocacy space to flag important issues. ... You are going to focus on the thing that is getting attention." 172

\section{B. Quantitative Evidence: Assessing the Transparency and Legality of Executive Agreements}

As noted above, when the State Department reports an executive agreement to Congress as required under the Case Act, it attaches a cover memo in which it identifies the agreement title, parties, dates of signature and entry into force, and, most important, the legal authority for the agreement. Under our settlement with the Department of State, we received 5,689 cover memos that the executive branch certified were the entirety of its records during the last four presidential administrations (between the dates of January 20, I989, and January 20, 2017), except for records relating to classified agreements. ${ }^{173}$ This is the first time that researchers have had access to this treasure trove of information. ${ }^{174}$ All of the data on which this Article relies, including the cover memos themselves, are available, together with dynamic data visualizations, through the Harvard Law Review's website. ${ }^{175}$

171 Interview by Oona Hathaway with Former U.S. Government Lawyer, supra note I69.

172 Interview by Oona Hathaway with Current U.S. Government Lawyer (May I9, 2020).

173 These were the dates of our FOIA request to the Department of State. There is reason to believe that the State Department may have been overresponsive to our request and included some cover memos that are outside of this date range. We kept these cover memos in the database and matched them to agreements in each of the databases described below even if the agreement fell outside the date range for the request.

174 For a description of how we obtained these memos, see Appendix A, infra pp. 72 I-22.

175 See Oona A. Hathaway, Curtis A. Bradley \& Jack L. Goldsmith, The Failed Transparency Regime for Executive Agreements: An Empirical and Normative Analysis: Data Visualizations, HARV. L. REV. (Dec. Io, 2020), https://harvardlawreview.org/executive-agreements-visualizations 
The memos, which are brief, allow us to examine two sets of key questions. First, we compared the agreements disclosed to Congress (based on the cover memos) with the agreements disclosed by the government to the public, as well as the more than six thousand agreements available from HeinOnline through private subscription during this same period. ${ }^{176}$ This comparison allowed us to determine whether the legal requirements above regarding publication and reporting of agreements were being followed in practice. We were able to examine the gaps between what could be made public and what is made public and between what should be reported and what is reported. Second, we were able to analyze the legal bases offered for the agreements. Working with our team of research assistants, we read and analyzed the thousands of separate legal authorities cited in the legal authority section of the cover memos to determine whether they could reasonably provide legal bases for negotiating and concluding binding executive agreements. Using this information, we were able to evaluate the strength of the legal justifications the government relies upon when it reports executive agreements to Congress. This empirical analysis sets the stage for Part III, where we discuss the implications of the findings for the effective working of the transparency regime and for the legality of executive agreements.

The comprehensive database that we built to analyze these questions also provides valuable insight into the extensive use of executive agreements by the federal government. Even as Article II treaties have nearly disappeared, the number of executive agreements has kept up a steady pace. Over the course of the last three decades, the federal government has concluded hundreds of executive agreements a year across a vast range of topics. HeinOnline alone lists hundreds of subject categories, ${ }^{177}$ which we grouped into twelve substantive categories: Defense (I,99I) agreements); Finance, Trade, and Investment (I,I66); Humanitarian (73I); Science, Space, and Technology (728); Environment, Conservation, and Energy (723); Law Enforcement (624); Transportation and Aviation (5 I3); Nonproliferation (353); Educational Exchanges and Cultural

(containing data visualizations and links to Dataverse, where the cover memos and underlying data used in this Article are posted).

176 This figure would be more than eight thousand if we included the I,423 "record-only" agreements, for which HeinOnline does not have the text.

177 The subject areas were distilled from the existing categorizations on HeinOnline and TIAS. Executive agreements on HeinOnline had an overarching Treaty in Force (TIF) Subject, a more granular "Short Title," a detailed "Description," and a "Kavass Subject Indexing" that overlapped with the first three. On TIAS, agreements were associated with either one general category or two categories (one being a subcategory to the other). While neither database seemed to categorize agreements systematically or consistently, categorizations followed patterns that could be used to group agreements into distinct subject areas. Taking the HeinOnline and TIAS categories as a starting point, one of our student assistants, Tobias Kuehne, consolidated those categories into twelve (plus miscellaneous) subject areas. 
Cooperation (235); Taxation (250); Diplomacy and Consular Affairs (I86); and Maritime (I82). ${ }^{178}$

I. Transparency of Executive Agreements. - In order to assess the State Department's compliance with its publishing and reporting obligations, we sought to compare the agreements reflected in the cover memos to those in publicly available databases of international agreements.

There are three databases of non-Article II agreements that those outside government can access. First, as noted in Part I, the State Department maintains an online database, TIAS, in which it publishes all executive agreements except for agreements that are classified or where "the public interest in such agreements is insufficient to justify their publication." ${ }^{179}$ TIAS is the primary database that the Department of State uses to make international agreements other than treaties public. Second, after some investigation, our team found an archived website (difficult to search for and no longer updated) where the State Department published unclassified agreements reported under the Case Act between 2006 and early 2013 (which we refer to as the Case Act Reports database). ${ }^{180}$

Finally, HeinOnline maintains a commercial database of international agreements but requires a paid subscription to access it. ${ }^{181}$ This database was initially compiled by Igor Kavass, who for twenty years served as director of the law libraries at Duke and Vanderbilt and wrote on international law. ${ }^{182}$ As the HeinOnline database (named "KAV" in his honor) description notes, he "spent much of his career identifying and obtaining treaties and agreements entered into by the United States since I950 that have not yet been published in UST or TIAS."183 Indeed, Kavass took it as his personal mission to construct the database

\footnotetext{
178 The numbers are based on analysis of executive agreements in HeinOnline that entered into force or were last signed between January 20, I989, and January 20, 2017. To explore these data further, please visit the dynamic data visualizations for this Article. See Hathaway et al., supra note I 75 .

179 I U.S.C. § I I2a(b)(2); see Treaties and Other International Acts Series (TIAS), supra note 3; supra p. 646.

180 See Reporting International Agreements to Congress Under Case Act, supra note 93; supra p. 647.

181 See KAV Agreements, HEINONLINE, https://home.heinonline.org/titles/World-Treaty-Library/KAV-Agreements [https://perma.cc/P $745-\mathrm{KWCP}]$. Some elements of the database can be viewed without a subscription, but full access requires a subscription.

182 Id.; Obituary, Igor Ivan Kavass, THE TennesseAn (Apr. 8, 2008), https://obits. tennessean.com/obituaries/tennessean/obituary.aspx?n=igor-ivan-kavass\&pid= I072 I 8294 [https:// perma.cc/59YE-SQG 3 ].

183 KAV Agreements, supra note I8r. Hein describes the U.S. Treaties and Agreements Library this way: "This library includes all U.S. treaties, whether currently in-force, expired, or not-yet officially published. It includes prominent collections such as the United States Treaties and Other International Agreements set (commonly referred to as the 'Blue set'), as well as famous sets from Bevans, Miller, Malloy and others." U.S. Treaties and Agreements Library, HeInONLINE, https://home.heinonline.org/u-s-treaties-and-agreements-library [https://perma.cc/ULZ ${ }_{9}-\mathrm{R}_{7} \mathrm{BC}$ ].
} 
the government lacked, building the most complete database of U.S. executive agreements - far more comprehensive than the government's own. ${ }^{184} \mathrm{He}$ was so personally responsible for building the HeinOnline database that at least one likely reason for the decline in the public availability of executive agreements after the mid-2000s was his death in 2008 .

(a) Publication. - When we first set out to explore how many of the cover memos pertain to agreements that have been made public, we expected that there would be more agreements reported to Congress than made public by the State Department or available by private subscription. While this turned out to be the case, the data brought some surprises. Comparing the datasets, we found the following 185 :

The TIAS dataset - the public site maintained by the U.S. government - includes just $31.43 \%$ of the unclassified agreements reported to Congress during the period of our FOIA request. Of our 5,689 cover memos, I,788 match agreements published in TIAS. ${ }^{186}$ This finding highlights that the publication of agreements by the government in TIAS is very far from comprehensive, perhaps because the executive branch, exercising its discretion under the relevant regulations, has concluded that a large percentage of agreements are not sufficiently important to be published. ${ }^{187}$ Whatever the reason, these statistics indicate that the government's current mechanism to publish international

184 See Igor I. Kavass, Researching International Law, 83 AM. SOC'Y INT'L L. PrOC. IO7, I Io (I989).

185 Using the information about the underlying agreement in each cover memo, we compared them to publicly available databases to identify probable matches. If the country name and subject were the same, and the date of the agreement was comparable, we recorded it as a "probable match." Because the databases list agreements by different dates, we were as generous as possible with date matching. TIAS lists agreements by the date they entered into force. The Case Act Report lists them by the year they were reported to Congress. HeinOnline lists the agreements by the date they were last signed, which is frequently the same date that they entered into force. As a result, the same agreement may be reported in TIAS in December 2009 (because that is the date of entry into force) but in the Case Act Report in January 2010 (because that was the date it was reported to Congress). We then compared the cover memos to the matched agreements, removing erroneous matches. We repeated this process for each of the three databases. Matching with HeinOnline also had another special consideration. While HeinOnline usually has the full text of an agreement, it sometimes has only a record of the agreement, without the text. See infra notes r89-19o. We considered an agreement a "match" only if the full text was available. However, we also included statistics below regarding these "record-only" agreements, to provide maximum information.

186 There were I,698 agreements in the TIAS database that matched I,788 cover memos. We use this second number to calculate the percentage $(\mathrm{I}, 788 / 5,689)$. The difference between these numbers is due to the fact that multiple cover memos (for example, for amendments and follow-on agreements) may match a single underlying agreement in TIAS.

187 There were some puzzling discrepancies, as well. HeinOnline listed 582 additional agreements with TIAS numbers, but those agreements were not in the TIAS database. These were likely drawn from the U.S. government publication Treaties in Force, which lists the agreements to which the United States is a party but not their text. See U.S. DeP'T OF State, Treaties IN Force (2020), https://www.state.gov/wp-content/uploads/2020/08/TIF-2020-Full-website-view.pdf [https:// perma.cc/5 $\left.\mathrm{Z}_{7} 6-\mathrm{F}_{7} \mathrm{PX}\right]$. 
agreements results in significantly incomplete public access to the country's binding executive agreements.

The Case Act Reports database - the archived website briefly maintained by the U.S. government - included $88.49 \%$ of the agreements reported in the cover memos for the short period that the database was active. Though it covered only eight years, the State Department Case Act Reports database contained almost as many agreements as TIAS during the period of our study (I989-20I 7 ): I,507 of the cover memos match agreements in the Case Act Reports database. ${ }^{188}$ If we exclude 2013 , when it reported only seven agreements, it included $94.48 \%$ of the agreements reported in the cover memos from the period in which it was maintained. Needless to say, the Case Act Reports database is more comprehensive than the TIAS database. This suggests that it is feasible for the State Department to much more comprehensively provide agreements to the public through an online website than it currently does because it has done so in the recent past.

HeinOnline is by far the most complete overall source for executive agreements, containing $82.93 \%$ of the agreements that were reported to Congress during the period of our FOIA request. The HeinOnline database is much more complete than the government-run databases of executive agreements. ${ }^{189}$ 4,7 I 8 cover memos match agreements in the HeinOnline database. ${ }^{190}$ We found that there are 2,454 cover memos or $43.14 \%$ of our dataset - that match agreements available only in HeinOnline. ${ }^{191}$ We reached out to HeinOnline to understand how it obtained so many more agreements than are available in government databases. Its representative explained:

[T]hrough a FOIA request Igor [Kavass] setup an arrangement for the State

Department to send [HeinOnline] any agreements they were sending to

\footnotetext{
188 I,507 cover memos match agreements in the Case Act Reports database. There are I,703 cover memos for agreements that entered into force between 2006 and 2013 (the years the database was active). Hence, the Case Act Reports database included $88.49 \%$ of the agreements reported in the cover memos during the period the database was active. However, because the Case Act Reports database's reporting of agreements may be delayed, this should be understood as an estimate.

189 Of the agreements in HeinOnline during this period, 2,87 I had TIAS numbers and 3,756 had KAV numbers only. In addition, HeinOnline cataloged 1,423 "record-only" agreements. Of those agreements, 276 had TIAS numbers, and I,I 47 had only KAV numbers. However, due to renumbering by HeinOnline and because sometimes the text of an underlying agreement, but not an amendment, was on HeinOnline, these numbers should be viewed as estimates.

190 In total, 5, I 50 agreements in HeinOnline (including record-only agreements) corresponded to 5,245 cover memos. Of the 5,150 agreements, the text of the agreement was available for only 4,643 agreements - or $90.16 \%$. One possible explanation for the gap between HeinOnline and TIAS is that Kavass may have defined agreements differently from the U.S. government — for example, treating political commitments as agreements. But the size of the gap suggests that this is unlikely to explain its entirety.

191 Puzzlingly, we also found that, for our time period, HeinOnline had 2,87 I agreements given TIAS numbers - more than the total number of agreements available in TIAS itself for the period $(2,287)$.
} 
Congress. These agreements contained temporary State Department Numbers which we recorded in [HeinOnline's] database. This flow went on for years and ceased when the State Department [adopted] their new TIAS numbering systems [in 2016]. ${ }^{192}$

In other words, the United States government provided "any agreements" that it was reporting to Congress to a researcher working on behalf of the subscription-based HeinOnline, but published only about a third of those in the government-run public database, TIAS. ${ }^{193}$ Kavass also "spent a good deal of time identifying international agreements that were in the National Archives that were never officially published by the State Department." ${ }^{194}$ As a result, a representative explained, HeinOnline "obtained a great number of agreement texts from the National Archive which were added to our database and our collection."195

Several current and former State Department lawyers responsible for maintaining the TIAS database told us that they consider HeinOnline's databases to be more comprehensive and reliable than the government's own TIAS database. They also said that it is not uncommon for a lawyer working on an agreement to have difficulty getting access to the most recent examples of similar agreements. In other words, the executive branch department responsible for organizing agreements and keeping the public and Congress informed about them cannot even keep itself organized and informed about them, and must instead rely on a private company. ${ }^{196}$ This is an obvious indication of a broken system.

The FOIA litigation produced cover memos for 605 agreements that were not published in any database. These 605 cover memos could not be matched to agreements in TIAS, the Case Act Reports database, or HeinOnline. HeinOnline cataloged, but did not have the text of, 3 I 4 of these agreements. Although these agreements are unclassified, it appears that we are providing the very first public indication of the existence of nearly 300 of them.

192 Email from Daniel Rosati, Chief Res. Officer, William S. Hein \& Co., Inc., to Oona Hathaway, Professor of L., Yale L. Sch. (YLS), \& Lucie Olejnikova, Head of Foreign \& Int'l L., Lillian Goldman L. Libr., YLS (Jan. 2 I, 2020, I2:I6 PM) (on file with the Harvard Law School Library). 193 See supra p. 668.

194 Email from Daniel Rosati to Oona Hathaway \& Lucie Olejnikova, supra note 192.

195 Id.

196 Problems relating to the executive branch's internal organization and record keeping with respect to international agreements are longstanding. See, e.g., U.S. GEN. ACCT. OFF., GAO/NSIAD-oo-24, InTERnATIONAL TRADE: IMPROVEMENTS NEEDED TO TRACK AND ARCHIVE Trade AGREEMENTS 4 (I999), https://www.gao.gov/assets/230/22853I.pdf [https://perma.cc/B8WU-H4 $\mathrm{Z}_{7}$ ] ("The number of trade agreements to which the United States is currently a party is uncertain. Officials at key agencies were unable to provide a definitive count of all U.S. trade agreements that are currently in force, despite the fact that the Office of the U.S. Trade Representative, State, and Commerce have created separate archives containing many agreements."). 
Figure I includes the number of agreements reported in each dataset each year. The comparison makes clear that HeinOnline's advantage over the other databases began to fall in the mid-200os. This is likely due to the fact that some of HeinOnline's special access declined in the wake of Igor Kavass's departure. TIAS, the official government database of international agreements, underperforms throughout. The Case Act Reports database, during the short period it was active, pretty well matches the cover memos. ${ }^{197}$ In sum, the official government database, TIAS, publishes only a fraction of the agreements reported to Congress - and it publishes far fewer agreements than are published by HeinOnline.

Figure I: Publication and Reporting of Executive Agreements ${ }^{198}$

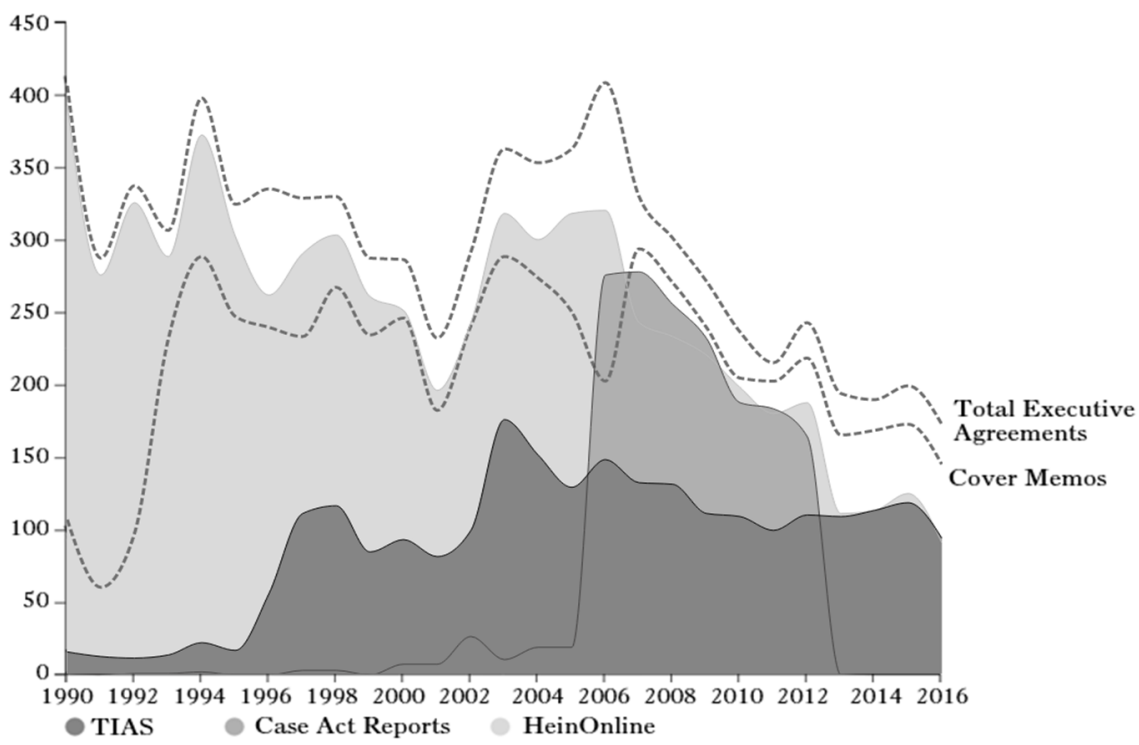

(b) Reporting. - The data also offer insights into how well the executive branch has met its obligations to report executive agreements to Congress. The State Department represented in U.S. district court that the cover memos it provided in response to our FOIA request represent a complete record of unclassified cover memos provided to Congress in the period from January 20,1989 , to January 20,2017 . It is not, therefore, unreasonable to treat the cover memos as evidence of all of the

197 The failure to obtain a perfect match is likely due at least in part to differences in dating. See supra note 185 .

198 Our thanks to Aucher Serr and Natalie Erdem, of Two-N, for creating this data visualization. To examine how these data have changed over time through dynamic data visualizations, see Hathaway et al., supra note I 75 . 
unclassified agreements that the executive branch reported to Congress during this period. If this inference is correct, then it appears likely that not all agreements were reported to Congress as legally required.

Figure I makes clear that HeinOnline published many more agreements in most years than the executive branch reported to Congress. Looking just at the cover memos, we see that, on average, there were about 200 each year. The highest was in 2007 , with 278 cover memos. The lowest was I99I, with fifty-eight cover memos. ${ }^{199}$ Comparing the three databases during the relevant time period, TIAS had an additional 6 Io agreements for which we did not receive cover memos, the Case Act Reports database had an additional I6 I agreements for which we did not receive cover memos, and HeinOnline had a whopping 2,027 agreements for which we did not receive cover memos. ${ }^{200}$ That gap has closed in recent years not, it appears, because reporting to Congress has become more comprehensive but rather because HeinOnline's access to nonpublic sources declined after Kavass's departure.

What's more, many of the agreements for which the State Department did not produce cover memos are exceptionally important. Take, for example, the Bilateral Security Agreement between the United States and Afghanistan. The agreement, which was concluded in 2014 and entered into force in 2015 , ensured that close to I0,000 U.S. troops would remain in Afghanistan to assist Afghan security forces in battling the Taliban. ${ }^{201}$ In addition, agreements dedicating between $\$ 40$ million and $\$ 258$ million in aid for a total of $\$ 85$ I million to the Afghan government after the Taliban was pushed from power were not reported in the cover memos we received. ${ }^{202}$ Other striking examples include an

199 Figure I shows cover memos reported to Congress between January 20, I989, and January 20,2017 , by date the agreement entered into force (where not available, we used the last reported signature date). We omitted $20 \mathrm{I} 7$ because few agreements that entered into force in $20 \mathrm{I} 7$ would have been reported before January 20, 2017. This figure shows that the number of agreements peaked in 2007 and then fell off precipitously. The reason for the falloff is unclear. There are several possibilities: (I) the government may have concluded many fewer executive agreements; (2) the government may have concluded just as many agreements but failed to report a higher percentage of them; or (3) more agreements were concluded as nonbinding commitments and thus were not subject to reporting requirements.

200 HeinOnline had 2,945, if agreements identified as existing but that were missing the full text are included.

201 See Declan Walsh \& Azam Ahmed, Mending Alliance, U.S. and Afghanistan Sign Long-Term Security Agreement, N.Y. TIMES (Sept. 30, 20I4), https://nyti.ms/InFrIBq [https://perma.cc/AQ 3 M$\left.\mathrm{SL}_{3} \mathrm{X}\right]$.

202 See Amendment No. Five to Strategic Objective Grant Agreement, Afg.-U.S., Sept. I8, 2006, Hein's No. KAV 7,765; Amendment No. Five to Strategic Objective Grant Agreement, Afg.-U.S., Sept. I8, 2006, Hein's No. KAV 7,764; Amendment No. Four to Strategic Objective Grant Agreement, Afg.-U.S., June 28, 2006, Hein's No. KAV 7,696; Amendment No. Four to Strategic Objective Grant Agreement, Afg.-U.S., June 28, 2006, Hein's No. KAV 7,695; Amendment No. Four to Strategic Objective Grant Agreement, Afg.-U.S., June 28, 2006, Hein's No. KAV 7,694; Amendment No. Three to Strategic Objective Grant Agreement, Afg.-U.S., May I I, 2006, Hein's 
agreement that provides for cooperation with Russia on peaceful uses of nuclear energy, a Joint Declaration on Security Alliance with Japan, a multilateral Agreement on a Comprehensive Political Settlement of the Cambodian Conflict, an agreement giving $\$$ I $_{5} 0$ million in aid to the Palestinian Authority, an agreement to heighten border security on the U.S.-Canada border, a 269-page free trade agreement between the United States and Australia, and an agreement creating a multilateral F/A-I 8 weapons program..$^{203}$ In short, they are not trivial commitments.

What explains this gap between agreements published by HeinOnline and those for which we received cover memos in response to our FOIA litigation? There are several possibilities. First, it is possible that there is a gap between what is available in HeinOnline and what is reported to Congress due to coordination issues within the executive branch - in particular that the State Department is not always notified about agreements being concluded by other departments or agencies, despite statutory and regulatory provisions mandating such notice. We know, for example, that agreements are concluded by the Office of the United States Trade Representative (USTR) using a process that USTR has treated as an alternative to the Case Act. ${ }^{204}$ Those agreements would not necessarily appear among those reported to Congress. ${ }^{205}$

To test this possibility, we examined whether the percentage of agreements missing cover memos varied across subject areas. We found that it did. For example, forty-five percent of finance, trade, and investment agreements did not have cover memos. This suggests that at least part

No. $\mathrm{KAV} 7,653$; Amendment No. Two to Strategic Objective Grant Agreement, Afg.-U.S., Apr. 6, 2006, Hein's No. KAV 7,607; Amendment No. Two to Strategic Objective Grant Agreement, Afg.U.S., Apr. 6, 2006, Hein's No. KAV 7,606; Amendment No. Two to Strategic Objective Grant Agreement, Afg.-U.S., Apr. 6, 2006, Hein's No. KAV 7,605.

203 Agreement for Cooperation in the Field of Peaceful Uses of Nuclear Energy, Russ.-U.S., May 6, 2008, T.I.A.S. No. I I-I I I; Joint Declaration on Security Alliance for the 2 Ist Century, JapanU.S., Apr. I7, I996, 36 I.L.M. I002; Agreement on a Comprehensive Political Settlement of the Cambodia Conflict, Oct. 23, I991, Hein's No. KAV 3,073; Cash Transfer Grant Agreement, Palestine-U.S., Oct. Io, 2008, Hein's No. KAV 8,532; Agreement for Cooperation in Science and Technology for Critical Infrastructure Protection and Border Security, Can.-U.S., June I, 2004, T.I.A.S. No. 04-60I; Free Trade Agreement, Austl.-U.S., May I8, 2004, Hein's No. KAV 6,422; Memorandum of Understanding Concerning the Cooperative Framework for the F/A-I 8 Program, Aug. 23-Sept. 23, 2005, Hein's No. KAV 7,426.

204 I9 U.S.C. § I872 establishes an interagency trade organization that includes the Secretary of State and can "perform such other functions with respect to the trade agreements program as the President may from time to time designate." I9 U.S.C $\$$ I872(b)(4); see id. § I872(a)(3)(C). According to interviews, attorneys at USTR have taken the position that agreements approved through this process could bypass the C-I 75 requirements, though State Department lawyers have disagreed, arguing that the $\S_{1} 872$ interagency organization does not have explicit authority to approve proposed international agreements. It is possible that other agencies or interagency committees may be using their own statutory authorizations to conclude agreements without properly reporting them to State.

205 For an outstanding, extensive examination of executive agreements in the trade area, see Kathleen Claussen, Trade Executive Agreements (Sept. I, 2020) (unpublished manuscript) (on file with the Harvard Law School Library). 
of the explanation is the conclusion of trade agreements outside the Case Act process. But trade accounted for only 530 of the $2,36 \mathrm{I}$ agreements that did not have cover memos, or about twenty-two percent.

Table 3: Agreements by Subject Area ${ }^{206}$

\begin{tabular}{|c|c|c|c|}
\hline Subject Area & $\begin{array}{c}\text { Total } \\
\text { Agreements }\end{array}$ & $\begin{array}{c}\text { Agreements } \\
\text { Without } \\
\text { Cover } \\
\text { Memo }\end{array}$ & $\begin{array}{c}\text { Percent } \\
\text { Without } \\
\text { Cover } \\
\text { Memo }\end{array}$ \\
\hline Defense & 1,991 & 342 & $17 \%$ \\
\hline $\begin{array}{l}\text { Finance, Trade, } \\
\text { and Investment }\end{array}$ & 1,166 & 530 & $45 \%$ \\
\hline Humanitarian & 731 & 123 & $17 \%$ \\
\hline $\begin{array}{l}\text { Science, Space, } \\
\text { and Technology }\end{array}$ & 728 & 177 & $24 \%$ \\
\hline $\begin{array}{c}\text { Environment, } \\
\text { Conservation, and Energy }\end{array}$ & 723 & 227 & $31 \%$ \\
\hline Law Enforcement & 624 & 305 & $49 \%$ \\
\hline $\begin{array}{l}\text { Transportation } \\
\text { and Aviation }\end{array}$ & 513 & 119 & $23 \%$ \\
\hline Nonproliferation & 353 & 80 & $23 \%$ \\
\hline Miscellaneous & 294 & 92 & $31 \%$ \\
\hline $\begin{array}{l}\text { Educational Exchanges } \\
\text { and Cultural Cooperation }\end{array}$ & 235 & 59 & $25 \%$ \\
\hline Taxation & 250 & 106 & $42 \%$ \\
\hline Maritime & 182 & 67 & $37 \%$ \\
\hline $\begin{array}{l}\text { Diplomacy and } \\
\text { Consular Affairs }\end{array}$ & 186 & 60 & $32 \%$ \\
\hline Total $^{207}$ & 8,050 & 2,361 & $29 \%$ \\
\hline
\end{tabular}

Second, it is possible that the State Department did report the agreements to Congress and made a genuine effort to locate information responsive to the FOIA request but failed to locate much of the relevant

206 For more data on the topics addressed by executive agreements and how they interact with other features of agreements, view the dynamic data visualizations in Hathaway et al., supra note I 75 .

207 There are seventy-seven agreements with no identified subject area that are therefore not reflected in the table, except for in the totals. One hundred percent of those agreements have no cover memo. 
material due to poor record keeping. There is significant evidence for this explanation as well. We have learned that many of the examples cited above were "misfiled" (the Bilateral Security Agreement between the United States and Afghanistan); were reported with the wrong cover memo (the F/A-I 8 weapons program agreement); fell into "known gaps" in department records of background statements believed to have been submitted; or were later discovered during a physical move of the offices (the Afghanistan assistance agreements). ${ }^{208}$ In addition, some of the agreements apparently were submitted to Congress prior to entering into force and under practice at the time did not include background statements (the Russia civil nuclear cooperation agreement and Australia free trade agreement apparently fall into this category).

Third, it may be that HeinOnline's database includes agreements that need not be reported under the Case Act. In particular, some of the agreements in HeinOnline for which we do not have a cover memo may be Article II treaties. ${ }^{209}$ But given that there are at most a few hundred Article II treaties and over 2,300 agreements without cover memos during the period under examination, that leaves a large number of executive agreements reported in HeinOnline for which there are no cover memos. These agreements might be "nonbinding," 110 so minor as to not qualify as international agreements according to the State Department, ${ }^{211}$ or implementing agreements that closely correspond to the terms of the underlying agreements. ${ }^{212}$ Indeed, the Joint Declaration on the Security Alliance with Japan cited above is apparently regarded by the Department of State as a nonbinding instrument and therefore

208 Email from Current U.S. Government Lawyer to Curtis Bradley (Sept. I6, 2020).

209 Table 3 offers some support for this hypothesis because "Taxation" and "Law Enforcement" are both areas where Article II treaties are common. The underreporting hypothesis is further supported, however, by additional evidence: As mentioned earlier, TIAS had 6 Io agreements that did not match the cover memos. A significant number of these were binding agreements effective upon signature or shortly after - hence not Article II treaties. That remaining gap indicates either that the State Department published some agreements that it failed to report to Congress or that its record keeping was poor, and it failed to provide cover memos to us for all of the agreements that it $d i d$ report. The former may be correct because only twenty-two of the 6ro agreements that were in TIAS but not in our cover memos appeared in the State Department Case Act Report Database.

210 See 22 C.F.R. § I8I.2(a)(I) (20I9) ("IIn order for an instrument to be an international agreement for the purposes of the Case Act,] [t]he parties must intend their undertaking to be legally binding, and not merely of political or personal effect. Documents intended to have political or moral weight, but not intended to be legally binding, are not international agreements.").

211 See id. § I8I.2(a)(2) (providing that "[m]inor or trivial undertakings, even if couched in legal language and form, are not considered international agreements within the meaning of the [Case] Act”).

212 See id. § I8I.2(c) ("An implementing agreement, if it satisfies the criteria discussed in paragraph (a) of this section, may be an international agreement, depending upon how precisely it is anticipated and identified in the underlying agreement it is designed to implement. If the terms of the implementing agreement are closely anticipated and identified in the underlying agreement, only the underlying agreement is considered and [sic] international agreement."). 
not subject to Case Act reporting. But, again, the number of agreements involved - in the thousands - far exceeds what would be expected if this were the explanation.

To test this last possibility - that HeinOnline includes agreements that are not subject to Case Act reporting - we generated a random sample of the unreported agreements. ${ }^{213}$ We found that twenty percent were Article II Senate-ratified treaties, nine percent were nonbinding, ${ }^{214}$ and two percent were implementing agreements that might qualify for the exception. We could not easily discern whether agreements were "minor or trivial" such that they are not reportable agreements within the meaning of the Case Act. None of them identified themselves in this way, of course, and most looked much like other executive agreements. In our judgment, about twenty percent of the agreements might qualify for this exception, but our identification of such agreements was made with a low level of confidence, given the absence of any clear public criteria. Our conclusion is that while these exceptions might justify some portion of the unreported agreements (perhaps as much as fifty percent, depending on how generously the "minor or trivial" exception is interpreted), well over a thousand apparently unreported agreements should have been reported.

In sum, the data suggest that either there has been systematic and consistent underreporting to Congress during much of the past three decades or the State Department incorrectly certified that its FOIA production was complete. The mismatch between what is available on HeinOnline and what the State Department disclosed in response to our FOIA litigation raises serious questions about whether the executive branch properly observes its reporting obligations.

Using the Case Act Reports database, we are also able to examine how well the State Department meets the obligation to report agreements in a timely manner. As explained in Part I, the Case Act requires that executive agreements be reported within sixty days after the agreement enters into effect. ${ }^{215}$ To determine how well that rule has been observed, we analyzed the State Department's own (now defunct) Case Act Reports database, which includes notations of when reports were submitted to Congress late. Based on that analysis, in the period from 2006-2013, about forty percent of the agreements included notations that they had been reported late. The government agencies most often blamed were the State Department (290 of 643 late-reported agreements), the Department of Defense (DOD) (I42), the U.S. Agency for International Development

213 The sample included ninety-two agreements of the 2,027 for which HeinOnline had an agreement for which there was no cover memo and where the underlying text of the agreement was available to be examined (HeinOnline lists a number of agreements for which it does not have the underlying text).

214 We were guided here by Guidance on Non-binding Documents, U.S. DeP'T OF STATE, https://2009-20I 7.state.gov/s/l/treaty/guidance/index.htm [https://perma.cc/FT6V-U6DX].

215 See I U.S.C. § I I 2 b(a); supra section I.B.2, pp. 648-5 I. 
(69), the Nuclear Regulatory Commission (27), the FAA (26), USTR (26), and NASA (20).

As the above account makes clear, after comparing the agreements reported to Congress with the agreements published to the public, we found both lacking. A large majority of executive agreements are never published, and many of them are not even reported to Congress. Moreover, the congressional reporting, when it does occur, is frequently late.

2. Legal Bases for Reported Agreements. - Next, we turn to the project of examining the legal bases for the agreements. Each cover memo includes a crucial section, "legal authority," that provides citations to the law on which the agreement is based. This information has not previously been available to scholars. Indeed, when in previous articles we wrote about executive agreements and attempted to determine the legal basis for an agreement, the only way to do so was to work backward: we had to examine the agreement and then try to determine what law, if any, might provide authority to conclude it. ${ }^{216}$ For the first time, the information in the cover memos offers direct and extensive access to the legal authorities under which the agreements were, in fact, concluded. Here we describe the types of authorities cited and assess the strength of the legal justifications the government relies upon when it reports executive agreements to Congress.

(a) Cited Authorities. - There are several different types of legal citations in the legal authority section of the cover memos. Here we break the authorities into two broad categories: citations to the U.S. Constitution and citations to nonconstitutional sources.

(i) Citations to the U.S. Constitution. - Among the cover memos, 3,915 cite the U.S. Constitution. That is sixty-nine percent of all cover memos. If these citations are meaningful, an assumption we question below, then the State Department relies on the Constitution as at least part of the authority for the majority of executive agreements. Just 374 cover memos cite only the Constitution. If the executive branch's assessment of the legal bases of agreements is accurate (once again an assumption we question below), approximately seven percent of the agreements during this period were what would traditionally be considered sole executive agreements.

(ii) Citations to Authorities Other than the U.S. Constitution. There are over 8,700 total citations to authorities other than the Constitution. There is an average of I.55 nonconstitutional authorities cited per cover memo. A majority of the cover memos $(3,295)$ cite only one nonconstitutional authority, but a large minority cite more than one. The most authorities cited in a cover memo is thirteen.

\footnotetext{
216 See Bradley \& Goldsmith, supra note 4, at I250; Hathaway, supra note 8 , at $245-46$. The former article examined one of these cover memos, concerning the Paris Agreement, which the authors obtained through informal means. See Bradley \& Goldsmith, supra note 4, at I 250.
} 
There is an immense amount of variation in how the legal authorities are cited. The same legal authority often is cited in numerous different ways within the same cover memo and among different cover memos for example, by statute name and section, statute number, or U.S. Code designation. ${ }^{217}$ Altogether, there are about I,000 unique authorities cited in the cover memos.

Citations to Prior Agreements. A minority of cover memos cite prior agreements. The vast majority of agreements cited are prior Article II treaties, but there are a handful of citations to congressional-executive agreements and even a few to sole executive agreements. There are I I 9 unique international agreements cited.

Citations to Executive Branch Documents and Authorities. The cover memos cite thirty-three different executive branch internal documents and authorities. For example, an Attorney General opinion is cited in fifty-four cover memos, and the Circular I 75 authority is cited in thirty. ${ }^{218}$

Citations to Statutes. The overwhelming majority of the nearly I,ooo unique authorities cited are statutes. The ten most cited statutes are as follows ${ }^{219}$ :

- The Foreign Assistance Act of i96 I

- The Cooperative Threat Reduction Act of I993

- The Arms Export Control Act

- The North Atlantic Treaty Organization (NATO) Mutual Support Act of 1979

217 For example, one of the most cited acts, the Foreign Assistance Act of I 96 I, is cited in seventyfour different ways, including "The Foreign Assistance Act of I96I, as amended," "Section 237 (a) of The Foreign Assistance Act of I96 I, as amended, 22 USC 2 I 97 (a)," "Section 505(a) of The Foreign Assistance Act of I96I, as amended," "Section 635(g) of The Foreign Assistance Act of I96I, as amended, 22 USC $2395(\mathrm{~g})$," "Sections 503, 505, and 54I of The Foreign Assistance Act of I $96 \mathrm{I}$, as amended," "Section 505 of The Foreign Assistance Act of $196 \mathrm{I}$, as amended," "Section 5 I 5 of The Foreign Assistance Act of I96I, as amended," "Section 48I(a)(2) of The Foreign Assistance Act of I96I, as amended," "Section 505 of The Foreign Assistance Act of I96I, as amended, 22 USC 23I4," and "Foreign Assistance Act of I96I, as amended, 75 Stat 424." To determine whether an authority is the "same" even if cited in a different format, we considered whether it refers to the same provision(s) of the legal authority. So a citation to an entire act would be treated differently from a citation to a single provision of that act. Similarly, a citation to two different provisions of a single act would be treated as two separate citations. We treated as the same citations to an act and an act "as amended."

218 It is important to note that we judged only the authority actually cited in the cover memos. It is entirely possible that there are cover memos that cite weak authorities but for which there may be a stronger available authority that is not cited.

219 There are also a number of statutes that are frequently cited, but which change on a regular basis, often every year. These include the National Defense Authorization Act; the Universal Postal Convention; the Foreign Operations, Export Financing, and Related Programs Appropriations Act; the Department of Defense Appropriations Act; dire emergency or miscellaneous appropriations; and the Internal Revenue Code. 
- The Federal Aviation Act of 1958

- The Atomic Energy Act of 1954

- The National Aeronautics and Space Act of ig6o

- The Agricultural Act of I956

- The Energy Reorganization Act of 1974

- The National Environmental Policy Act of r969

(b) Quality of Cited Authority. - Working with our team of research assistants over the course of two years, we read and analyzed the thousands of nonconstitutional legal authorities cited to determine whether the authorities cited in each memo could reasonably provide the legal basis for negotiating and concluding the corresponding binding executive agreement. ${ }^{220}$ Our aim was to determine how strong the cited legal basis was for each agreement - how often did a cover memo cite a legal authority that gave express authority to conclude the agreement to which it was attached, and how often was the authority weaker?

We categorized each of the authorities as falling into one of five categories, detailed below. Only cited authorities in the first category give explicit authority to the President to conclude an executive agreement. The cited authorities that fall into the second, third, and fourth categories all approve some form of international negotiation or cooperation by the President, but Congress has not made clear in them that it intends to authorize the President to enter into or conclude a binding commitment. Those in the fifth category provide no arguable authority to conclude executive agreements. ${ }^{221}$ More specifically, the five-point scale is as follows:

I: Express authorization to conclude agreements. Cited authorities with this code give clear authority to enter into an agreement, which may also be referred to as a convention, treaty, amendment, memorandum of understanding, or arrangement. With 524 citations, the Foreign Assistance Act of I96I, as amended, is the most commonly cited statute

220 Katrin Marquez, Danielle Zucker, Sasha Dudding (all YLS '20), and Pardis Gheibi (YLS 'I9) coded each authority according to a five-point scale. They also provided valuable insights into the cited authorities. The research team met with Oona Hathaway regularly over the course of nearly two years and went over the coding decisions as a group to ensure consistency throughout the coding process. A second team of four Yale undergraduates - Ariq Hatibie, Sam Larkin, Kate Pundyk, and Tiana Wang — assisted in final data preparation, as did YLS student Ayoub Ouederni '2 I - who also assisted in database comparisons and analytics. A final group of research assistants - Natalie Giotta, Tobias Kuehne, Jared LeBrun, Preston Lim, Randi Michel, and Nicole $\mathrm{Ng}$ - helped fill in additional information.

221 If a cited authority fell into more than one category, it was rated according to the highest category. (So, if a statute granted both express authority to conclude agreements and to negotiate agreements, it was coded I.) 
coded I. ${ }^{222}$ This does not come as a surprise. One of the authors of this Article noted in an earlier work on executive agreements that the Foreign Assistance Act of I96 I authorizes commitments in a range of different subject matter areas and helped drive the emergence of executive agreements as the key way in which international agreements are made by the United States. ${ }^{23}$ But what the earlier work could not anticipate is that the citations are frequently to the Act as a whole - rather than to its particular sections. This is radically imprecise. The Foreign Assistance Act of 196I is, in its most recent amended form, 285 pages long. ${ }^{224}$ In those 285 pages, there is a wide array of grants of authority to conclude agreements on specific topics. Yet the entire Act is cited in cover memos for agreements on everything from providing radar data, to strengthening good governance in Afghanistan, to strengthening South Africa's health care system, to supporting reconstruction in Honduras after Hurricane Mitch.

2: Authorization to negotiate agreements. Cited authorities with this code grant authority to negotiate an agreement but do not expressly confer authority to conclude an agreement. Whether the grant of authority to negotiate necessarily entails authority to conclude is an unresolved question. As a result, we determined that authority to negotiate and authority to conclude or enter a binding agreement were different enough that they should be coded separately. ${ }^{225}$ Only cited authorities that create new negotiating authority were coded 2.

With 239 citations, 22 U.S.C. $\S 2656 \mathrm{~d}^{226}$ is the most cited authority coded 2. It provides:

In order to implement the policies set forth in section $2656 \mathrm{~b}$ of this title, the Secretary of State ... shall have primary responsibility for coordination and oversight with respect to all major science or science and technology agreements and activities between the United States and foreign countries, international organizations, or commissions of which the United States and one or more foreign countries are members. ${ }^{227}$

The statute proceeds to confer additional related authority. Section $2656 \mathrm{~b}$, meanwhile, states:

222 The Foreign Assistance Act is cited in many alternative forms. See supra note 2 I7. Those multiple alternative forms are included in the data posted on Dataverse.

223 See Hathaway, supra note 8, at I59, I6 I-63, I88-9I.

224 FOREIGN ASSISTANCE ACT OF I96 I (2019), https://www.foreign.senate.gov/imo/ media/doc/Foreign\%20Assistance\%20Act\%20Of\%20 I 96 I.pdf [https://perma.cc/UH8P-SQW8].

225 Given the information learned in interviews above, it is possible that some of the citations to statutes that provide for negotiation are due to the fact that some of the $\mathrm{C}-\mathrm{I} 75$ memos are prepared for both negotiation and conclusion. It would be reasonable for such a memo to cite negotiating authority, even if that authority would not support concluding the agreement.

226 Here, we included references to "22 U.S.C. $2656(\mathrm{~d})$," because there is no 22 U.S.C. $§ 2656(\mathrm{~d})$, and therefore, we concluded that such references were simply mistaken references to $\S 2656 \mathrm{~d}$.

22722 U.S.C. $\$ 2656 \mathrm{~d}(\mathrm{a})(\mathrm{I})$. 
[T]he Congress declares the following to be the policy of the United States: .. . The mutually beneficial applications of technology in bilateral and multilateral agreements and activities involving the United States and foreign countries or international organizations should be recognized and supported as an important element of United States foreign policy. ${ }^{228}$

Although the scope of authority granted by this language is debatable, we concluded that these provisions, taken together, provide authority to negotiate bilateral and multilateral agreements on science or science and technology but do not provide sufficiently explicit authority to conclude an agreement to be coded I.

3: Authorization to furnish assistance (supplies, services, loans, etc.) to foreign countries or authority to make purchases or enter into other economic arrangements. This category includes the authority to spend, furnish financial assistance, enter into contracts, or otherwise engage in commerce with foreign actors. It further includes authorizations to give money to or receive money from other nations, ${ }^{229}$ to make transfers of property to other countries (for example, transfers of forfeited property), ${ }^{230}$ to receive support and assistance (not just give it), and to acquire "logistic support, supplies, and services." 231 The idea here is that, by authorizing these interactions, Congress may also be authorizing the conclusion of binding agreements to facilitate them. Importantly, if the cited authority allows the executive branch to spend, furnish financial assistance, enter into contracts, or otherwise engage in commerce but does not reference any foreign actors or indicate that the authorization contemplates international transfers, then we coded it as a 5 , rather than a 3 .

Io U.S.C. $\S 2559$, which is cited eighty times, is the most cited statute coded 3. It mandates that "whenever the Secretary of Defense provides medical care in the United States on an inpatient basis to foreign military and diplomatic personnel or their dependents, the Secretary shall require that the United States be reimbursed for the costs of providing such care."232 It also allows for reciprocal provision of medical care to military personnel and their dependents from a foreign country if the other nation provides comparable care to "a comparable number of U.S. military personnel and their dependents in that foreign country."233

4: Authorization to engage in international cooperation with foreign countries or establish a "program" with foreign countries (for example, for exchange of information). This may include authority to create a

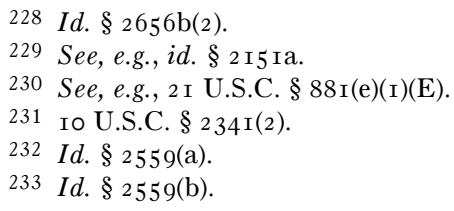


new international program, engage in international cooperation, or exchange information. Again, the idea here is that such an authorization might implicitly also convey some authority to conclude facilitating agreements. The Cooperative Threat Reduction Act of $1993,{ }^{234}$ cited 202 times, is the most cited authority coded 4. It authorizes "the President [to] conduct programs . . . to assist . . . states of the former Soviet Union in [their] demilitarization."235 In particular, "[t]he President is authorized to designate a Demilitarization Enterprise Fund ... to receive grants ... and use the grant proceeds to provide financial support ... for demilitarization of industries and conversion of military technologies and capabilities into civilian activities." ${ }^{236}$ This language clearly contemplates a program of cooperation but does not expressly grant authority to conclude an agreement.

5: No arguable delegation of agreement-making authority. This category includes statutes that establish new agencies, such as the Nuclear Regulatory Commission or Department of Homeland Security; delegate existing authority to negotiate to particular actors - for example, the Secretary of State; describe duties of an officer more generally (without more); authorize the issuance of regulations (without more); contain mere definitions; or grant authority to conclude an "agreement" without any explicit or obvious implicit reference to any international or global context. ${ }^{237}$ If a statute confers authority to spend, furnish financial assistance, enter into contracts, or otherwise engage in commerce but includes no reference to any foreign actors or indication that the authorization contemplates international transfers, then it was coded 5 ; if there were references to international or foreign actors, it was coded 3 . If the cited authority delegates or refers to authority that is granted elsewhere but does not itself grant authority, then it was coded 5 .

22 U.S.C. $\$ 2656$, which is cited 57 I times, is the most frequently cited authority coded 5 . It merely provides:

The Secretary of State shall perform such duties as shall from time to time be enjoined on or intrusted to him by the President relative to correspondences, commissions, or instructions to or with public ministers or consuls from the United States, or to negotiations with public ministers from foreign states or princes, or to memorials or other applications from foreign public ministers or other foreigners, or to such other matters respecting foreign affairs as the President of the United States shall assign to the Department,

\footnotetext{
23422 U.S.C. $\$ \S 595 \mathrm{I}-5958$.

235 Id. $\S 5952$ (a).

236 Id. $\S 5953$.

237 We include here citations to statutes or other authorities that appear in the cover memos but do not appear to refer to real legal authorities. Some of these are likely typos. If a citation is to an authority we believed exists but we could not locate, we coded it as N/A. There are only three of these, and they are all executive agreements that appear to have not been published.
} 
and he shall conduct the business of the Department in such manner as the President shall direct. ${ }^{238}$

In other words, the statute describes the position of Secretary of State but grants no new authority relating to agreements. Subsequent statutory provisions (including 22 U.S.C. $\$ 2656 \mathrm{~d}$, described above) may provide authority to conclude agreements, but this provision alone offers none.

The percentage of authorities coded at each level - I through 5 is reflected in Figure 2 below. A plurality $(37.5 \%)$ of cited authorities were coded 5 - that is, they provide no arguable delegation of agreementmaking authority. Weighing them by the frequency with which they were cited, the percentage of cited authorities coded 5 falls slightly to thirty-four percent, and the percentage of authorities coded I jumps from twenty-eight percent to thirty-four percent.

Figure 2: Percentage of Unique Coded Authorities, by Code

\section{Unique Authorities}

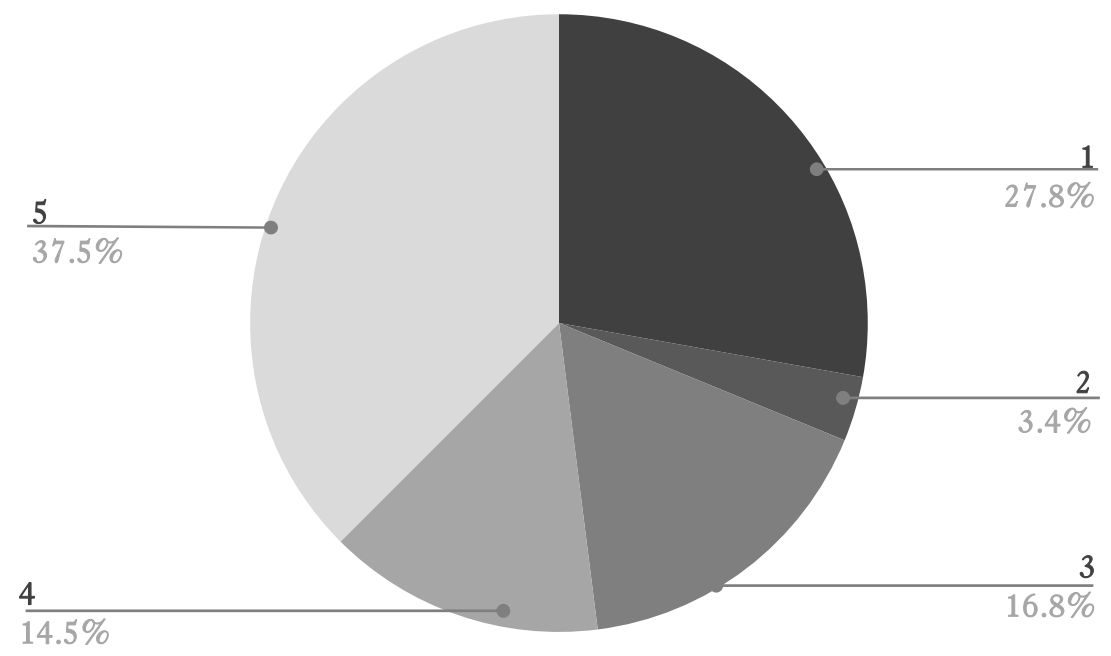




\section{Unique Authorities, Weighted by Frequency}

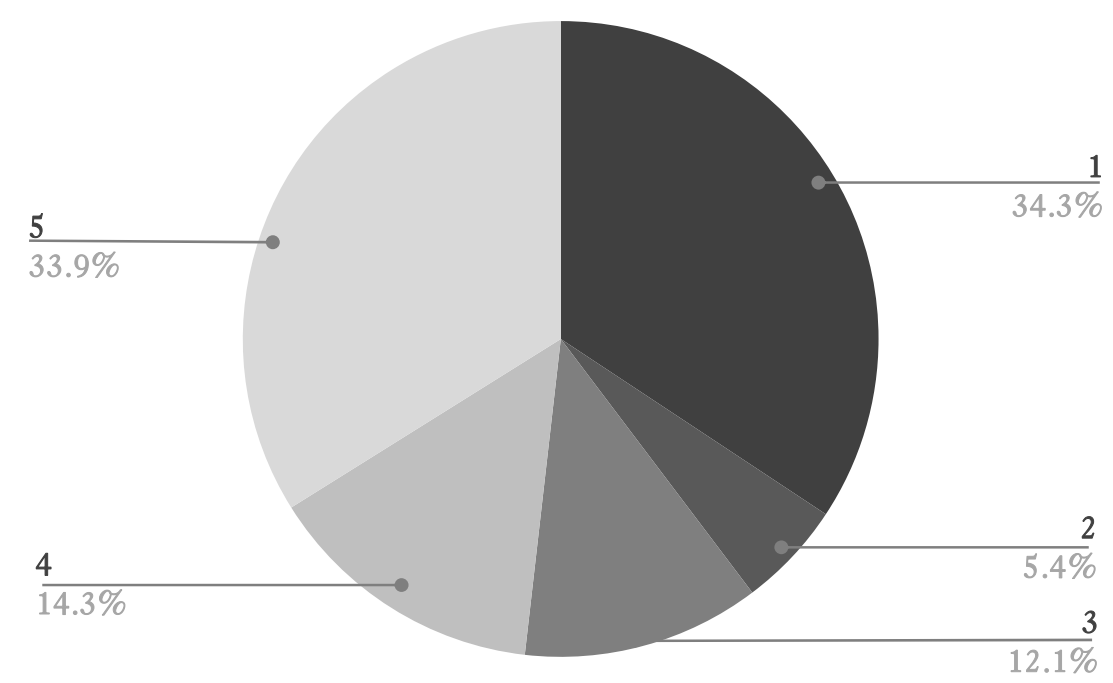

(c) Assessing Strength of Legal Authority for Each Agreement. Using the ratings of each authority, we then assigned an overall rating to each cover memo based on the citation with the highest rating. Of the 5,689 cover memos we received, we found that 2,52 I (44.3 I \%) rely on a legal authority with the highest code of I (express authority to enter an agreement), I,799 (31.62\%) rely on an authority coded $2-4$ (something less than express authority), and 983 (I $7.28 \%$ ) rely on authorities with the highest code of 5 (no authority). Of those that cite only an authority coded $5,74.77 \%$ also cite Article II of the Constitution, a slightly higher percentage than the rate in the cover memos overall $(68.82 \%)$. Twelve memos cite no legal authority whatsoever (0.2 I \%), and 374 cite only the Constitution (6.57\%).

It is worth emphasizing that the most important distinctions for our purposes are between agreements in category I, agreements in categories 2-4, and agreements in category 5 . Those in category I are easiest to defend as based on express authority, those in category 5 are the hardest to defend, and those in the middle categories are debatable. We ranked category 2 above 3 or 4 because authorities with this coding usually contemplate future agreements, even though they do not expressly authorize them. 3s come next because they entail dedication of assistance to foreign countries, and that assistance is typically subject to conditions established in international agreements. Those involved in negotiating these agreements tell us that it can be difficult to effectively impose the conditions Congress establishes in any other way. There is also a long history dating back to the Foreign Assistance Act of r96 I of using executive agreements for this purpose. Last, 
$4 \mathrm{~s}$ indicate a general intent of Congress to encourage international cooperation but involve no direct connection to executive agreements. But others might rank agreements in these middle categories differently. ${ }^{239}$

Table 4: Legal Authorities Cited in Cover Memos

\begin{tabular}{|ccc|}
\hline Highest Code & $\begin{array}{c}\text { Number of Cover } \\
\text { Memos }\end{array}$ & $\begin{array}{c}\text { Percentage of Cover } \\
\text { Memos }\end{array}$ \\
\hline 1 & 2,521 & $44.31 \%$ \\
2 & 411 & $7.22 \%$ \\
3 & 695 & $12.22 \%$ \\
4 & 693 & $12.18 \%$ \\
5 & 983 & $17.28 \%$ \\
Constitution Only & 374 & $6.57 \%$ \\
No Authority & 12 & $0.21 \%$ \\
\hline
\end{tabular}

Looking at the total number of citations overall to each type of authority over time, as displayed in Figure 3, we see that they have been fairly consistent.

Figure 3: Legal Authorities over Time ${ }^{240}$

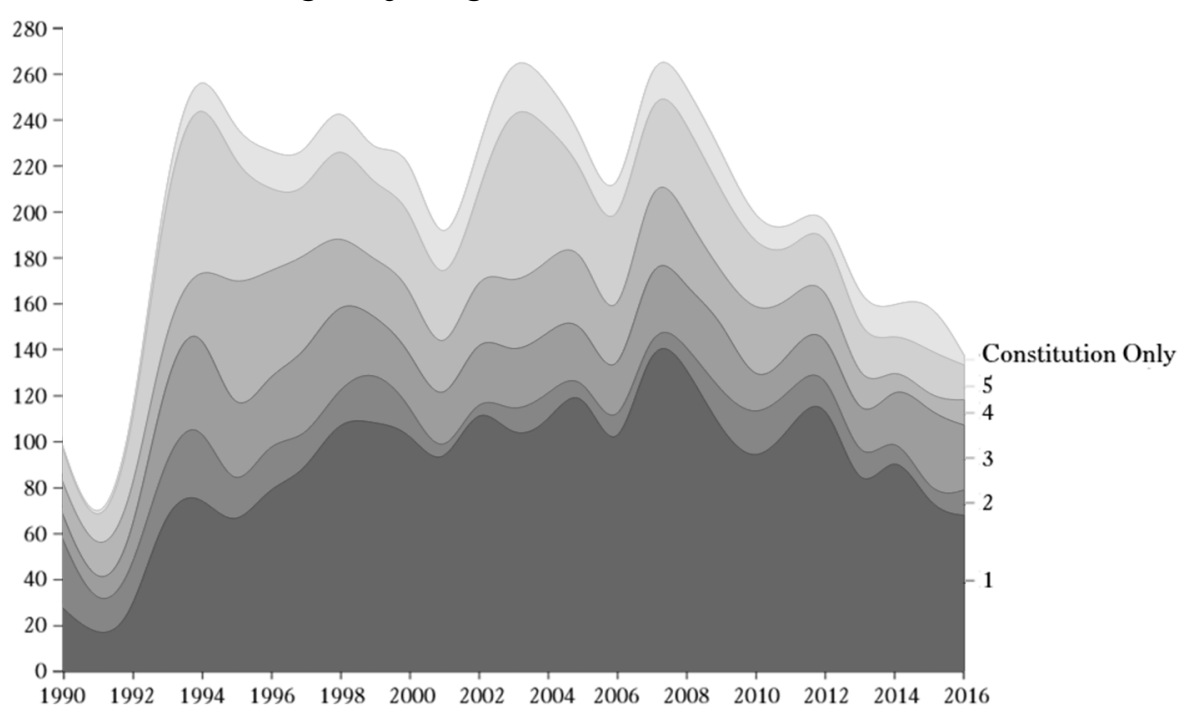

239 All underlying data will be made public on Dataverse, allowing those who would rank these differently to test how that would change the results. See Hathaway et al., supra note I 75 (providing dynamic data visualizations and access to underlying data through Dataverse).

240 Our thanks to Aucher Serr and Natalie Erdem, of Two-N, for creating this data visualization. To examine how the legal authorities the government relies on for executive agreements have changed over time, view the dynamic data visualizations in Hathaway et al., supra note I 75 . 
It is also worth noting that these numbers are stacked in favor of finding authority to enter agreements. That is because we assess only whether the cited authority provides express authority to enter into any international agreement. For the purposes of the figures above, we $d o$ not assess whether the authority in fact provides express authority to enter into the agreement for which it is cited. Doing so is extremely time intensive, requiring a careful assessment of whether a cited legal authority authorizes the actions to which the United States commits in a particular agreement - which may be lengthy and contain many different obligations. It also requires access to the text of the underlying agreement, which is not always available.

We did conduct this deeper analysis for a statistically significant sample of agreements that cite at least one authority in category i to see, for each agreement, if the cited authority in fact expressly authorizes the executive branch to conclude that particular agreement. ${ }^{241}$ We found that for seventy-six percent of agreements that cite at least one authority coded I, the authority coded I authorizes the executive branch to conclude the particular agreement for which it is cited. Among the roughly twenty-four percent of agreements where a cited authority coded I does not authorize the executive branch to conclude the particular agreement, the authority falls into one of several categories: (I) The cited authority does not support the agreement for which it is cited, but there is another cited authority that does provide express support. ${ }^{242}$ (2) A cited statute had been repealed at the time it was cited. The impact was de minimis, however, because the statute repealing the authority provides for the same authorizations in another section of the statute that is not cited. ${ }^{243}$

\footnotetext{
241 We analyzed a random sample of ninety-three agreements out of $2,5^{2} \mathrm{I}$ that cite at least one statute coded I, allowing us to calculate a ninety-five percent confidence interval with a ten percent margin of error. A team of research assistants led by Nicole $\mathrm{Ng}$ then read the agreements and assessed whether the cited statutes coded I in fact provided support for the agreements for which they were cited. If not, they noted the reasons for the discrepancy.

242 Fifty-nine percent of the agreements for which a cited authority coded I does not provide express support for the agreement fell into this category (or fourteen percent of agreements overall in the sample). For example, the cover memo for the Agreement Concerning the Establishment of a Tropical Forest Conservation Fund and a Tropical Forest Conservation Board, Bots.-U.S., Oct. 5, 2006, T.I.A.S. No. 06-i I 9, cites two statutes coded I: the Tropical Forest and Coral Reef Conservation Act of I998, 22 U.S.C. $\S 243 \mathrm{I}, 243 \mathrm{Ia}-243 \mathrm{Ik}$, and a section of the Foreign Assistance Act of I96 I, 22 U.S.C. $\$ 243$ og. The second does not support the agreement because it only authorizes agreements concluded with Latin American or Caribbean countries and thus excludes Botswana. See 22 U.S.C. $\S \S 2430 b(a), 2430$ g. But the agreement meets the requirements for conservation agreements expressly authorized by the Tropical Forest Conservation Act. See id. $\S 243 \mathrm{IC}(\mathrm{a})$.

243 The three agreements in this category all cite the same repealed statute. For example, the cover memo for the Agreement Relating to the Employment of Dependents of Official Government Employees, U.S.-Uru., June 26-July I4, 2008, T.I.A.S. No. 08-7 I4.I, concluded with Uruguay, cites section 40I(a) of the Foreign Relations Authorization Act, Fiscal Year 1979, Pub. L. No. 95-426, $\S 40 \mathrm{I}(\mathrm{a}), 92$ Stat. 963,977 (1978), which was repealed in relevant part in October I980 by the
} 
(3) The cited authority does not provide express authority, but it provides some lesser authority for the agreement. ${ }^{244}$ (4) The cited authority provides no authority for the agreement at all. ${ }^{245}$ There were only three agreements that fell into this last category. Hence, overall, our analysis of this sample suggests that the technique we adopted - of assessing the cited authorities independent of the agreements - may be slightly generous to the government but does not lead to wildly different results than had we engaged in agreement-by-agreement analysis of all of the cited authorities.

There is, moreover, variation across subject areas in terms of the strength of the authorities cited in the cover memos. As we can see from Table 5, some areas (for example, Diplomacy and Consular Affairs and Humanitarian Aid) usually rely on express authority, and some areas (for example, Transportation and Aviation and Law Enforcement) rely regularly on authorities we judged to be quite weak.

Foreign Service Act of 1980, Pub. L. No. 96-465, 94 Stat. 207 I (codified as amended in scattered sections of 5 and 22 U.S.C.); see id. $\$ 2205(2)$, 94 Stat. at 2160 . However, the 1980 Act provides in another section for the same authorization that supports concluding the agreement. See id. $\S 220$ I(a), 94 Stat. at 2 I 54 (codified at 22 U.S.C. \$ 2699 (a)). The cover memo for the agreement does not cite that new provision.

244 For example, the cover memo for the Agreement Relating to the Export-Import Bank of the United States, Supplementing the Investment Incentive and Financial Agreement of December I6, I992, Peru-U.S., May 20, I 994, T.I.A.S. No. I 2,542, cites "sections 2(a) and 2(b) of the Export-Import Act of 1945 , as amended (I2 U.S.C. 635)." The cited provisions contain a narrow express authorization to enter into international agreements, but that authorization is unrelated to the subject of this particular agreement. See I2 U.S.C. $\S 635(\mathrm{~b})(\mathrm{I})(\mathrm{A})$ (authorizing "international agreements to reduce government subsidized export financing”). However, the cited authority does support a coding of 3 for this agreement, because the law directs the Export-Import Bank to provide guarantees and insurance to finance exports of goods and services, which the agreement seeks to facilitate. See id.

245 Three agreements fell into this category. The Agreement Regarding the Assignment of Foreign Liaison Officers, Arg.-U.S., Feb. 7-Apr. I 7, 2007, Hein's No. KAV 8,037, relies on 22 U.S.C. $\S 2347 \mathrm{c}$. That statute does not support this agreement because the statute provides for the attendance of foreign military personnel at professional military education institutions or flight training schools in the United States and only authorizes agreements for programs at "training locations in Southwest Asia." Id. § $2347 \mathrm{c}(\mathrm{c})(\mathrm{I})$. The cover memo for the Agreement Regarding the Prepayment of Certain Debts Owed to, Guaranteed by, or Insured by the United States Government and Its Agencies, Peru-U.S., Sept. 25, 2007, Hein's No. KAV 8,275, cites the Act of Nov. 29, I999, Pub. L. No. I06-II3, II3 Stat. I50I, and I2 U.S.C. § 635i-8. Both statutes authorize debt relief but only for countries eligible to borrow from the International Development Association, which Peru is not. See Act of Nov. 29, I 999, $\$ 557$ (b)(3), I I 3 Stat. at I50 I A-IoI; I 2 U.S.C. $\$ 635$ i-8(b)(2)(A)(ii). Finally, the cover memo for the Agreement Regarding the Status of United States Personnel Who May Be Temporarily Present in Uruguay, U.S.-Uru., Feb. I3-23, 2007, Hein's No. KAV 8,006, cites Io U.S.C. $\S_{1} 68$. That statute authorizes military-to-military contacts and international defense personnel exchanges to encourage a democratic orientation of foreign militaries, but the agreement provides for privileges and immunities to be granted to U.S. military and civilian personnel temporarily present in Uruguay for an upcoming presidential visit. See id.; Agreement Regarding the Status of United States Personnel Who May Be Temporarily Present in Uruguay, supra. 
Table 5: Legal Authorities Across Subject Areas

\begin{tabular}{|c|c|c|c|c|c|c|c|}
\hline & $\neg$ & $\sim$ & $m$ & $\forall$ & in & 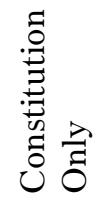 & 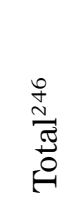 \\
\hline Defense & $\begin{array}{c}818 \\
(50 \%)\end{array}$ & $\begin{array}{c}3 \\
(0.2 \%)\end{array}$ & $\begin{array}{c}323 \\
(20 \%)\end{array}$ & $\begin{array}{c}83 \\
(5 \%)\end{array}$ & $\begin{array}{c}200 \\
(12 \%)\end{array}$ & $\begin{array}{c}219 \\
(13 \%)\end{array}$ & 1,649 \\
\hline $\begin{array}{l}\text { Diplomacy and } \\
\text { Consular Affairs }\end{array}$ & $\begin{array}{c}103 \\
(82 \%)\end{array}$ & $\begin{array}{c}0 \\
(0 \%)\end{array}$ & $\begin{array}{c}8 \\
(6 \%)\end{array}$ & $\begin{array}{c}7 \\
(6 \%)\end{array}$ & $\begin{array}{c}3 \\
(2 \%)\end{array}$ & $\begin{array}{c}5 \\
(4 \%)\end{array}$ & 126 \\
\hline $\begin{array}{c}\text { Educational } \\
\text { Exchanges and } \\
\text { Cultural } \\
\text { Cooperation }\end{array}$ & $\begin{array}{c}104 \\
(59 \%)\end{array}$ & $\begin{array}{c}2 \\
(1 \%)\end{array}$ & $\begin{array}{c}18 \\
(10 \%)\end{array}$ & $\begin{array}{c}1 \\
(1 \%)\end{array}$ & $\begin{array}{c}44 \\
(25 \%)\end{array}$ & $\begin{array}{c}7 \\
(4 \%)\end{array}$ & 176 \\
\hline $\begin{array}{c}\text { Environment, } \\
\text { Conservation, } \\
\text { and Energy }\end{array}$ & $\begin{array}{c}289 \\
(58 \%)\end{array}$ & $\begin{array}{c}47 \\
(9 \%)\end{array}$ & $\begin{array}{c}15 \\
(3 \%)\end{array}$ & $\begin{array}{c}94 \\
(19 \%)\end{array}$ & $\begin{array}{c}35 \\
(7 \%)\end{array}$ & $\begin{array}{c}16 \\
(3 \%)\end{array}$ & 496 \\
\hline $\begin{array}{l}\text { Finance, Trade, } \\
\text { and Investment }\end{array}$ & $\begin{array}{c}238 \\
(37 \%)\end{array}$ & $\begin{array}{c}146 \\
(23 \%)\end{array}$ & $\begin{array}{c}72 \\
(11 \%)\end{array}$ & $\begin{array}{c}5 \\
(1 \%)\end{array}$ & $\begin{array}{c}158 \\
(25 \%)\end{array}$ & $\begin{array}{c}16 \\
(3 \%)\end{array}$ & 636 \\
\hline Humanitarian & $\begin{array}{c}504 \\
(83 \%)\end{array}$ & $\begin{array}{c}13 \\
(2 \%)\end{array}$ & $\begin{array}{c}46 \\
(8 \%)\end{array}$ & $\begin{array}{c}18 \\
(3 \%)\end{array}$ & $\begin{array}{c}19 \\
(3 \%)\end{array}$ & $\begin{array}{c}8 \\
(1 \%)\end{array}$ & 608 \\
\hline Law Enforcement & $\begin{array}{c}64 \\
(20 \%)\end{array}$ & $\begin{array}{c}4 \\
(1 \%)\end{array}$ & $\begin{array}{c}28 \\
(9 \%)\end{array}$ & $\begin{array}{c}47 \\
(15 \%)\end{array}$ & $\begin{array}{c}127 \\
(40 \%)\end{array}$ & $\begin{array}{c}49 \\
(15 \%)\end{array}$ & 319 \\
\hline Maritime & $\begin{array}{c}65 \\
(57 \%)\end{array}$ & $\begin{array}{c}14 \\
(12 \%)\end{array}$ & $\begin{array}{c}2 \\
(2 \%)\end{array}$ & $\begin{array}{c}7 \\
(6 \%)\end{array}$ & $\begin{array}{c}14 \\
(12 \%)\end{array}$ & $\begin{array}{c}13 \\
(11 \%)\end{array}$ & 115 \\
\hline Miscellaneous & $\begin{array}{c}122 \\
(60 \%)\end{array}$ & $\begin{array}{c}5 \\
(2 \%)\end{array}$ & $\begin{array}{c}3 \\
(1 \%)\end{array}$ & $\begin{array}{c}49 \\
(24 \%)\end{array}$ & $\begin{array}{c}15 \\
(7 \%)\end{array}$ & $\begin{array}{c}4 \\
(2 \%)\end{array}$ & 202 \\
\hline Nonproliferation & $\begin{array}{c}54 \\
(20 \%)\end{array}$ & $\begin{array}{c}3 \\
(1 \%)\end{array}$ & $\begin{array}{c}45 \\
(16 \%)\end{array}$ & $\begin{array}{c}149 \\
(55 \%)\end{array}$ & $\begin{array}{c}11 \\
(4 \%)\end{array}$ & $\begin{array}{c}11 \\
(4 \%)\end{array}$ & 273 \\
\hline $\begin{array}{l}\text { Science, Space, } \\
\text { and Technology }\end{array}$ & $\begin{array}{c}73 \\
(13 \%)\end{array}$ & $\begin{array}{c}163 \\
(30 \%)\end{array}$ & $\begin{array}{c}18 \\
(3 \%)\end{array}$ & $\begin{array}{c}185 \\
(34 \%)\end{array}$ & $\begin{array}{c}93 \\
(17 \%)\end{array}$ & $\begin{array}{c}17 \\
(3 \%)\end{array}$ & 551 \\
\hline Taxation & $\begin{array}{c}41 \\
(28 \%)\end{array}$ & $\begin{array}{c}2 \\
(1 \%)\end{array}$ & $\begin{array}{c}40 \\
(28 \%)\end{array}$ & $\begin{array}{c}0 \\
(0 \%)\end{array}$ & $\begin{array}{c}57 \\
(40 \%)\end{array}$ & $\begin{array}{c}4 \\
(3 \%)\end{array}$ & 144 \\
\hline $\begin{array}{l}\text { Transportation } \\
\text { and Aviation }\end{array}$ & $\begin{array}{c}46 \\
(12 \%)\end{array}$ & $\begin{array}{c}9 \\
(2 \%)\end{array}$ & $\begin{array}{c}77 \\
(20 \%)\end{array}$ & $\begin{array}{c}48 \\
(12 \%)\end{array}$ & $\begin{array}{c}207 \\
(53 \%)\end{array}$ & $\begin{array}{c}5 \\
(1 \%)\end{array}$ & 394 \\
\hline
\end{tabular}

In sum, we arrived at a number of conclusions about the executive agreements in our dataset:

The executive branch cites an authority that provides express permission to enter international agreements less than half of the time that it

246 The totals listed here include a small number of agreements that cite no authority. 
enters into executive agreements. The data show that just under half of the cover memos $(44.3 \mathrm{I} \%)$ cite at least one authority coded I.

When it does not have express authority, the executive branch is often able to cite some source of authority (to negotiate, offer assistance, or cooperate). This finding is consistent with the interviews, which suggested that it is common for executive branch officials to rely on legal authorities that do not expressly authorize them to enter into a binding international agreement as long as they provide some suggestion that Congress contemplated international cooperation. ${ }^{247}$

In $17.28 \%$ of cases, the authority cited by the executive branch does not plausibly provide any authority to enter into an international agreement. About seventeen percent of the cover memos fail to cite an authority coded higher than a 5. It should be noted, however, that seventyfive percent of this subset also cite Article II of the Constitution. It is possible, then, that some and perhaps many of these agreements are properly considered sole executive agreements, even though they purport to rely not only on the Constitution but also on some other authority ${ }^{248}$ as well. If one adds up the categories where the government relies exclusively on the Constitution and those where it relies on extremely weak statutory authority, they sum to $23.85 \%$. Whether these are properly sole executive agreements depends on whether they can rest on the President's constitutional authority alone. We are not able to evaluate that question here, although it is worth noting that this percentage far exceeds most estimates of the percentage of sole executive agreements, and the executive branch does not appear to be representing them as such.

Of the 245 agreements that rely solely on a statutory or other authority coded 5, without reference to Article II, many follow the same basic formats. One hundred thirty-nine of the 245 agreements $(57 \%)$ follow one of three boilerplate templates ${ }^{249}$ : (I) an investment incentive

247 See supra p. 664. We did not examine whether citations to something less than express statutory authority to conclude agreements are commonly coupled with underlying domestic authority for the President to act in the substantive areas covered by the agreements. Further exploring how this process works in particular substantive areas would be a valuable project for follow-on research.

248 We occasionally use the term "statutory authority" as shorthand to refer generally to nonconstitutional authorities cited in the cover memos, which, as noted above, may include prior international agreements and executive branch documents and authorities. See supra p. 678 .

249 While many of the agreements that cite only an authority coded 5 consist of these boilerplate templates, not all agreements using these templates reference the same authority, and thus not all agreements were coded the same way. For example, TIAS No. I $2,55^{2}$ follows the U.S. Geological Survey template but also cites a statute coded 2. Memorandum of Understanding on Cooperation in Geoscience, Russ.-U.S., at 2, June 23, I994, T.I.A.S. No. I2,552. Similarly, KAV 7,360 follows the debt restructuring template but references a statute coded 3. Agreement Regarding the 
agreement; ${ }^{250}$ (2) a memorandum of understanding with the U.S. Geological Survey; ${ }^{251}$ or (3) an agreement on debt consolidation, rescheduling, and refinancing. ${ }^{252}$ Looking at the subject matter of the agreements, 206 of the 245 agreements $(84 \%)$ are categorized as "finance, trade, and investment" (IOI); "defense" (47); or "science, space, and technology" (58). Interestingly, the agreements citing weak statutory authorities that do not also reference Article II almost entirely end in $2005 .{ }^{253}$ This does not hold if agreements that also cite Article II are included; they extend through the end of the dataset and include a substantial number of "transportation and aviation" and "law enforcement" agreements. ${ }^{254}$

Consolidation and Rescheduling of Certain Debts Owed to, Guaranteed by, or Insured by the United States Government and Its Agencies, Congo-U.S., July 8, 2005, Hein's No. KAV 7,360.

250 There are sixty-three total agreements following this template. See, e.g., Investment Incentive Agreement, Egypt-U.S., July I, I999, T.I.A.S. No. I3,05 I; Investment Incentive Agreement, KenyaU.S., Dec. 3, I 998, T.I.A.S. No. I3,008; Investment Incentive Agreement, S. Kor.-U.S., July 30, I 998 , T.I.A.S. No. I2,980; Investment Incentive Agreement, Pak.-U.S., Nov. I8, I 997, T.I.A.S. No. I 2,903; Investment Incentive Agreement, Para.-U.S., Sept. 24, I992, T.I.A.S. No. I2,478; Investment Incentive Agreement, Geor.-U.S., June 27, I992, T.I.A.S. No. I $2,463$.

251 There are forty-three total agreements following this template. See, e.g., Memorandum of Understanding Concerning Scientific and Technical Cooperation in the Earth Sciences, Nor.-U.S., Nov. 25, 2003 , T.I.A.S. No. O3-I I 25.I; Memorandum of Understanding Concerning Scientific and Technical Cooperation in the Earth Sciences, Turk.-U.S., Feb. 7-Apr. I0, 2002, T.I.A.S. No. 02-410; Memorandum of Understanding Concerning Scientific and Technical Cooperation in the Earth Sciences, Alg.-U.S., Feb. 2 I, 2000, T.I.A.S. No. I3,08I; Memorandum of Understanding Concerning Scientific and Technical Cooperation in the Earth Sciences, Braz.-U.S., May I8-Nov. 4, I998, Hein's No. KAV 5,423; Memorandum of Understanding Concerning Scientific and Technical Cooperation in the Earth Sciences, Mali-U.S., Apr. 23, I996, Hein's No. KAV 4,6 I 2 ; Memorandum of Understanding Concerning Scientific and Technical Cooperation in the Earth Sciences, MoroccoU.S., Aug. 27-Oct. I I, I993, T.I.A.S. No. I2,I66.

252 There are thirty-three total agreements following this template. See, e.g., Agreement Regarding the Consolidation and Rescheduling of Certain Debts Owed to, Guaranteed by, or Insured by the United States Government and the Agency for International Development, U.S.Viet., Apr. 7, 1997, Hein's No. KAV 4,906; Agreement Regarding the Consolidation and Rescheduling of Certain Debts Owed to, Guaranteed by, or Insured by the United States and Its Agencies, Alg.-U.S., Mar. 27, I996, Hein's No. KAV 4,607; Agreement Regarding the Consolidation and Rescheduling of Certain Debts Owed to, Guaranteed by, or Insured by the United States Government and Its Agencies, Croat.-U.S., Feb. I, I996, Hein's No. KAV 4,7 I4; Agreement Regarding the Consolidation and Rescheduling of Certain Debts Owed to or Guaranteed by the United States Government, Russ.-U.S., Sept. 30, I993, Hein's No. KAV 3,690; Agreement Regarding the Consolidation and Rescheduling or Refinancing of Certain Debts Owed to, Guaranteed by, or Insured by the United States Government and Its Agency, Eth.-U.S., May 3, I993, Hein's No. KAV 3,577; Agreement Regarding the Consolidation and Rescheduling or Refinancing of Certain Debts Owed to, Guaranteed by, or Insured by the United States Government and Its Agencies, Sierra Leone-U.S., Apr. I9, I993, Hein's No. KAV 3,562; Agreement Regarding the Consolidation and Rescheduling or Refinancing of Certain Debts Owed to, Guaranteed by, or Insured by the United States Government and Its Agencies, Peru-U.S., Aug. 27 , I992, Hein's No. KAV 3,392.

253 The exceptions are one agreement in 2006 and one in $20 \mathrm{I}$.

254 Of the 72 I cover memos that cite both an authority coded 5 and Article II, I9I are categorized as "transportation and aviation," I5O as "defense," and I 25 as "law enforcement." They do not frequently repeat any specific boilerplate templates. 
This Part has examined how the system for making executive agreements works in practice. It has shown that the transparency regime that Congress established to monitor such agreements is failing in a number of respects. Not only do the American people have no easy way to learn what binding international agreements have been concluded in their name, but Congress, too, seems to have been left out of the loop on thousands of international agreements in the last few decades. Moreover, within the executive branch itself, there appear to be significant problems with record keeping, coordination, and monitoring. Finally, in terms of the output of this system, the executive branch is concluding a majority of agreements without express authority from Congress.

Before turning in the next Part to consider possible reforms to address these pathologies, it is important to note that we have not assessed whether the broken transparency regime for executive agreements is producing bad agreements as a policy matter - that is, agreements that are not in the national interest. It would be very difficult for us to evaluate that issue, which would require a highly contextual analysis of each agreement, its policy aims, and the extent to which it achieved those aims and served the national interest. Any such assessment would likely turn on contestable assumptions and would be impossible to do on a large scale. The transparency regime for executive agreements is designed to allow Congress, both directly and by hearing from interested parties, to evaluate these questions, and we can state confidently from our data that the system is not working well toward that end. While the policy desirability and soundness of an agreement are obviously important issues, so too are the issues of whether the executive branch is complying with its statutory duties that are a prerequisite to congressional oversight, and whether the Executive is acting lawfully in entering into these agreements. The failures of the transparency system implicate these concerns independent of the underlying policy desirability of the agreements.

\section{PATHOLOGIES AND REFORM}

The FOIA materials that we obtained reveal significant noncompliance with several legal duties and raise questions about the legal basis for many agreements and the adequacy of the overall system of accountability for such agreements. Our interviews with former officials corroborate these points. They also reveal that the executive branch is poorly structured to meet its legal duties. In implementing its transparency obligations, the State Department is understaffed, underresourced, and poorly organized. It also lacks adequate arrangements with other agencies to ensure that it receives agreements and related information in a timely manner so that it can meet its legal duties. Finally, the data and interviews make plain that Congress has failed in its oversight duties by allowing these dysfunctions to persist. 
This is an unacceptable state of affairs from any normative perspective. Executive agreements create binding obligations on the United States under international law, and they often have either direct or indirect influences on domestic law. ${ }^{255}$ As we explain below, the President's independent constitutional foreign affairs powers can in some circumstances give the President more leeway in crafting international agreements for the United States than he or she has in making domestic law. ${ }^{256}$ But the leeway does not go so far as to permit widespread disregard of statutory duties concerning reporting and publication of those agreements, or negligent inattention to the legal bases for the agreements.

Our proposals for reform fall into two related categories. Section III.A addresses the lack of compliance with statutory and regulatory publication and reporting requirements. This compliance problem, we argue, requires two types of reform. First, the executive branch bureaucracy should be reorganized to ensure that all pertinent agreements are centrally collected, akin to the way that the Federal Register requires centralized collection of federal regulations. Second, a central executive branch repository, which we propose to be the State Department, should publish all nonclassified international agreements, just as all nonclassified statutes and regulations are published. Section III.A also addresses the problem of publication and reporting for nonbinding political commitments.

The second category of reform, addressed in section III.B, concerns the uncertain legality of many of the agreements. This section briefly reiterates our empirical findings about the range of legal bases for the agreements and the inadequacies in the State Department's presentation of legal authority for the agreements. As discussed in Part I, the scope of the executive branch's legal authority to conclude executive agreements is not entirely clear. Even accounting for that lack of clarity, however, there are significant questions about the legal justification for many executive agreements. Section III.B concludes by proposing mechanisms to improve the public legal justification for international agreements - mechanisms that, we believe, will make it more likely that agreements in the future will possess an adequate legal basis.

Before turning to these proposals, we should explain why they do not run afoul of the so-called "inside/outside fallacy." 257 This is the fallacy of premising the descriptive or diagnostic part of a paper on assumptions about the particular motivations of relevant officials (such as self-interest or indifference) and then offering prescriptions that

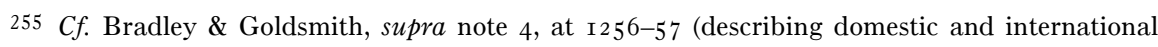
consequences of presidential control over international law, including over executive agreements).

256 See infra p. 7 I3.

257 See generally Eric A. Posner \& Adrian Vermeule, Inside or Outside the System?, 80 U. CHI. L. REV. I 743 (20I3).
} 
assume officials are guided by quite different motivations (such as public-spiritedness). Our reform proposals do not make such inconsistent assumptions. We accept the reasons why Congress has delegated significant agreement-making authority to Presidents, such as its recognition of executive branch expertise and the need for flexibility. We also recognize that Congress might be poorly structured, or inadequately motivated, or both, to engage in fine-grained oversight of executive agreements. Our proposals do not make heroic suppositions about official motivations or capacity.

Indeed, in contrast to many proposed reforms related to the separation of powers, the proposals below build on the known aims and actions of the two political branches. As we showed in Part I, Congress has for decades been concerned about problems with executive branch transparency, especially reporting, in this context. It has reflected this concern in a number of statutory amendments and funding restrictions that sought to solve the problem, but failed. The congressional staffers whom we interviewed confirmed continuing congressional frustration that the statutory requirements are not being followed. As we showed in Part II, former State Department officials have acknowledged problems in executive branch organization and transparency related to executive agreements. The State Department has taken steps in the recent past to try to fix the problems, and has sometimes sought more authority from Congress to do so. Our data provide new and concrete evidence about the various problems that Congress and the State Department have worried about and tried to address for decades.

Our proposals thus can be seen as an effort to provide solutions to problems that Congress and the executive branch have already themselves identified and expressed an interest in fixing. Moreover, congressional motivations are not static. Congress can and sometimes does focus more intently on an issue at particular times - often unexpectedly, perhaps prompted by a particular controversy. This happened, for example, when it first enacted the Case Act. Finally, our proposed reforms do not make unrealistic assumptions about Congress's ability to engage in robust oversight of executive agreements. Indeed, many of the proposed reforms are designed to inform the public (including civil society groups) about executive agreements and their legal bases so that the public can monitor and identify problems that Congress might want to address.

\section{A. Improving the Collection and Reporting of Agreements}

This section proposes reforms to redress the executive branch's poor record of reporting its agreements to Congress and the public. It begins by briefly summarizing our critique of the current system and then identifying the likely causes of the problems. It then describes what we believe to be the best model for reform: the Federal Register system for 
collecting and reporting federal regulations. Finally, it argues that executive agreements should be subject to internal collection and external transparency rules akin to ones that govern federal regulations, with modifications appropriate to the international agreements context.

In developing the arguments below, we are conscious of the growing literature that highlights the potential dangers of transparency mandates, including reduced government deliberation, the empowerment of lobbyists at the expense of ordinary citizens, and diminished confidence in institutions. ${ }^{258}$ This literature shows that transparency mandates can sometimes be harmful on balance, but not that they are invariably or even usually bad. The primary caution that emerges from these arguments is that scholars should "drill down into the specific legal, institutional, historical, political, and cultural contexts in which [transparency] policies are crafted and implemented" to discern if they are justified in context. $^{259}$ We agree. We do not advocate transparency simply for transparency's sake but rather aim to provide specific recommendations for targeted transparency reforms, while noting both plausible benefits and costs. We will return to this point below.

I. Transparency Issues that Emerge from the Data. - Compressing only a little, the legal requirements for publication and reporting international agreements are quite simple: as discussed in Part I, the State Department must publish to the world all nonclassified agreements other than ones excluded by regulation, and under the Case Act it must report to Congress all agreements (with special procedures for reporting classified agreements). To enable the State Department to meet these legal obligations, all executive agencies are obligated to transmit the text of concluded agreements to State within twenty days of signing. Our investigations have uncovered numerous problems with this regime.

The most obvious problem is that the State Department and other agencies are not fully complying with the Case Act and its regulations. As noted above, 2,027 agreements appeared in the HeinOnline database but were not reported with cover memos from January 20, I989 to January 20, 20I7. ${ }^{260}$ In addition, for the agreements that the State Department does report to Congress, many are reported late, beyond the Case Act's sixty-day rule. As we noted in Part I, this problem has long been documented in a piecemeal fashion in different years through dif-

\footnotetext{
258 See generally, e.g., TERo ERKkIlÄ, GOVERnMENT Transparency: IMPACTS AND Unintended Consequences (2012); OnORA O'NeILl, A Question OF Trust (2002); David E. Pozen, Freedom of Information Beyond the Freedom of Information Act, I65 U. PA. L. REV. 1097 (20I7); David E. Pozen, Transparency's Ideological Drift, I28 YALE L.J. 100 (2018).

259 David E. Pozen, Seeing Transparency More Clearly, 80 PUB. ADMIN. REV. 326, 326 (2020).

260 See supra p. 672. As noted earlier, the number is 2,945 if we include agreements for which HeinOnline has identifying data but not the text of the agreement. See supra note 200.
} 
ferent types of publications. The data reported here provide new support for this conclusion. They indicate that from 2006-20I3, about forty percent of agreements were reported late. Other, more recent materials suggest that this high percentage of untimely reporting is continuing. ${ }^{261}$ This suggests that the Congressional Research Service was too optimistic in its $200 \mathrm{I}$ study when observing that the timeliness of reporting seemed to be improving. ${ }^{262}$ Congress has frequently complained about late reporting going back as far as the I970s, and it has taken various steps to try to ameliorate the problem. But significant late reporting persists.

In the aggregate, the underreporting and late reporting constitute serious and persistent violations of important congressional and regulatory directives that are designed to ensure at least minimal presidential accountability in an important area of U.S. foreign relations. What explains these violations?

First, one explanation for the underreporting revealed by our analysis of the cover memos might be that some or all of the missing agreements were reported to Congress, but without cover memos, which were all that we requested from the State Department in our FOIA request. This explanation is unlikely and not consistent with information obtained in interviews, which suggests that only small numbers of agreements are reported without cover memos - nothing close to this scale. If this were the explanation, however, then the State Department would not be complying with its regulatory reporting duty to include a cover memo including a "precise citation of legal authority" for each agreement. Another possibility is that HeinOnline's database includes thousands of documents in its international agreements database that are not reportable under the Case Act, most likely nonbinding commitments. That seems equally unlikely, as it would imply a scale of reliance on such commitments never before suggested. If this were the explanation, it would indicate that the use of nonbinding commitments has become a major way of avoiding the reporting requirements of the Case Act. We have no reason to believe that is true (though such documents may explain a small part of the gap). Whether the bulk of the discrepancy is explained by underreporting, reporting without cover memos, a failure to produce all the relevant cover memos as legally required under our FOIA litigation settlement, or some combination, the State Department appears to be in serious undercompliance with its legal obligations.

261 See, e.g., U.S. Gov't ACCOUntability OfF., GAO-20-309, Defense Logistics AGREEMENTS I, I 7 (2020), https://www.gao.gov/assets/7 Io/705 I Io.pdf [https://perma.cc/4HBR5QZJ] (finding that forty-one percent of "acquisition and cross-servicing agreements," $i d$. at $\mathrm{I}$, which provide billions of dollars of logistic support, supplies, and services to more than Ioo partner countries, were reported late under the Case Act).

262 See CRS TREATY STUDY, supra note I4, at 228; supra p. 653. 
Second, an important explanation for late reporting and underreporting is that executive branch agencies often fail to send agreements to the State Department in a timely fashion, ${ }^{263}$ perhaps because they lack adequate guidance or adequate legal compulsion. This explanation is supported by statements that accompany many of the agreements that were reported in the Case Act Reports database, which more than half of the time during the period 2006-2013 note that if a report was made late, it was because the Department of State received the agreement late from the agency that concluded it. It is also supported by what we have been able to learn about the discrepancies between HeinOnline's data and the cover memos: HeinOnline appears to have obtained a number of agreements from agency records held by the National Archives. That suggests that State may not have received the agreements. This explanation is supported, as well, by a recent Government Accountability Office report on defense logistics agreements, which found that fortyone percent of the agreements were transmitted after the Case Act deadline "largely because DOD did not provide required information to State."264

This is not a new problem. As discussed in Part I, Presidents were required until 2000 to report to Congress about the timeliness of Case Act submissions, and these reports showed that a significant percentage of the agreements were being reported late, often because the State Department had not received the agreements from other executive departments in a timely manner. ${ }^{265}$ Similarly, in I999 the General Accounting Office reported, with respect to trade agreements, that "Congress may not have received all of the agreements and accompanying documents, as required by law."266 It explained that a likely reason was that the agreements were never provided to the Department of State: "In spring I 999 officials in Treaty Affairs told us that they believed many USTR-negotiated trade agreements had never been transmitted to State for review. According to the State officials, they had previously raised this issue with USTR on several occasions." 267 The USTR is almost certainly not alone in failing to report to the State Department. ${ }^{268}$ Congress's various piecemeal reform efforts to improve compliance have not led to significant improvements, in part because

263 This assessment is based on annotations that accompany the late-reported agreements on the Case Act Reports database.

264 U.S. GOV'T ACCOUNTABILITY OFF., supra note 26I, at preface. The report further indicated that "[ $\mathrm{f}]$ or two agreements that entered into force in $\mathrm{I} 983$ and 2002 , State records are insufficient to determine whether or not State notified Congress." Id. at I 7 . There was no evidence, however, that agreements were concluded by DOD but not transmitted to State. See id.

265 See id. at 28 ; supra p. 653.

266 U.S. GEN. ACCT. OFF., supra note I96, at I5.

267 Id.

268 As we note above, the USTR cannot account for the entire difference because only twentytwo percent of unreported agreements in our database (530 out of a total of $2,36 \mathrm{I}$ ) are on the subject of trade. See supra Table 3, p. 674. 
the efforts have not recognized or sought to seriously address the scale of the problem.

Third, many of the problems we have identified appear to result from the State Department's lack of sufficient resources dedicated to recording, reporting, and publishing executive agreements. Several former State Department officials mentioned insufficient money, personnel, and technology to address the issue. We cannot discern whether this problem results from inadequate funding by Congress, misplaced allocation of funds by the Department, or some combination of the two. But it is clear that whatever the reason, the Department lacks sufficient resources dedicated to meeting its statutory and regulatory obligations. In addition, while we do not believe that State Department officials are purposefully defying the law, it is clear from the interviews and data that fixing the problems we have identified has often not been a priority.

Fourth, the data highlight another transparency problem related to publication that demands explanation. The State Department's TIAS database contains just under a third of all U.S. nonclassified agreements during our time period. The data do not reveal whether the difference between all nonclassified U.S. agreements and the published ones is explained by pathologies akin to ones that occur under the Case Act, or whether they are explained by the regulations that permit the Department not to publish less important agreements. It might be some of both. ${ }^{269}$

2. Reform Proposals. - The best model for reforming the broken system of collecting and reporting executive agreements, we contend, is the Federal Register system that has long governed the collection and organization of federal regulations.

In I934, at the dawn of the New Deal, Erwin Griswold wrote an influential essay about the need to organize and publish the mass of federal regulations then emerging from the U.S. government. ${ }^{270}$ Griswold noted that regulations and related executive directives were

269 As a partial solution, one might imagine relying on the other parties to the agreements to disclose the agreements. After all, the agreements, by definition, have at least one other state party. Indeed, there is at least one instance where the content of an executive agreement came to light in the United States through its partner. See Bill Delahunt \& Oona Hathaway, Opinion, Bush Should Include Congress, BOS. GLOBE (Nov. 26, 2008), http://archive.boston.com/bostonglobe/ editorial_opinion/oped/articles/2008/I I/26/bush_should_include_congress/?page=full

[https://perma.cc/3 $\mathrm{BX}_{5}-\mathrm{A}_{4} \mathrm{P}_{4}$ ] ("[President Bush] has insisted on keeping the American people in the dark by refusing to release the English text of the agreement, while in Iraq the Arabic version is available to all."). But relying on other nations to inform the American public about the agreements its government makes will inevitably lead to a reporting regime that is incomplete and subject to the particular laws and practices of other countries, and thus is clearly inadequate as a means of ensuring transparency in this country.

270 Erwin N. Griswold, Government in Ignorance of the Law - A Plea for Better Publication of Executive Legislation, 48 HARV. L. REV. I98 (I934). 
practically as important as federal statutes. But, in looking at their organization and publication, he found "chaos." 271 Since there was no centralized mandatory system for collection, organization, and publication of the regulations, citizens (and their legal advisors), and even government officials, had no reliable way of knowing which ones were in force, or whether they had been amended, superseded, or withdrawn. They thus had no way to understand what the government had done in the exercise of federal regulatory power or to know how to conform behavior to government prescriptions.

To Griswold, the situation was so obviously unacceptable in a nation committed to the rule of law that its reform required little normative justification. This was especially so, he believed, since "the solution [was] amazingly simple."272 Griswold noted that statutes were centrally reported and publicly available. "All that is needed," he noted, "is an official publication, analogous to the Statutes at Large, in which all rules and regulations shall be systematically and uniformly published." 273 Thus was born the idea for the Federal Register Act, ${ }^{274}$ which Congress enacted in I935. ${ }^{275}$ The Act created an organization under the Archivist of the United States, and established a series of legal duties that together today ensure that nonclassified regulations are promptly collected, centrally stored, published, and then organized in a searchable fashion.

Here, in a nutshell, is how the Federal Register system for regulations works today. Each agency must publish its rules of procedure and substantive federal regulations of general applicability in the Federal Register. ${ }^{276}$ It must also designate a "liaison officer" to represent it "in all matters relating to the submission of documents to the Office of the Federal Register, and respecting general compliance" with reporting rules. $^{277}$ The liaison officer must provide an original copy of each final regulation, as well as two duplicate copies, to the Director of the Federal

\footnotetext{
271 Id. at 204.

272 Id. at 205 .

273 Id.

274 Ch. 4I 7, 49 Stat. 500 (I935) (codified as amended at 44 U.S.C. $\$$ I 5 OI-I 5 II).

275 For detailed histories of the Federal Register Act, see Lotte E. Feinberg, Mr. Justice Brandeis and the Creation of the Federal Register, 6I PuB. Admin. Rev. 359 (200I); and Harold C. Relyea, The Federal Register: Origins, Formulation, Realization, and Heritage, 28 GOV'T INFO. Q. 295 (2OII).

2765 U.S.C. $\$ 552(\mathrm{a})(\mathrm{I})$. The Federal Register is maintained by the National Archives and Records Administration's Office of the Federal Register (OFR). See 44 U.S.C. § I502. OFR promulgates the Federal Register in print, through microfiche, and online as PDFs. I C.F.R. $\S 5$.IO (2020); see also About the Federal Register, NAT'L ARCHIVEs (Aug. 8, 2018), https://www. archives.gov/federal-register/the-federal-register/about.html [https://perma.cc/UF 5 J-J4 4 8]. It also maintains an unofficial online version. Id. Classified agency rules and regulations need not be published. See GoITEIN, supra note 94, at 44-45.

277 See I C.F.R. § I6.2. That person, or another designated person, must certify that true copies are submitted to the Office of the Federal Register. $I d$. $§$ I6.3.
} 
Register for publication in the Federal Register. ${ }^{278}$ The Office of the Federal Register then publishes the regulation in the Federal Register in several media. ${ }^{279}$ Most regulations must be published not less than thirty days before their effective dates. ${ }^{280}$ Each agency has a duty to get the regulation to the Federal Register in time to meet this requirement. 281 There appear to be two mechanisms for ensuring compliance with these publication duties. First, a person who lacks actual notice of a regulation that is not timely published cannot be bound or burdened by it. ${ }^{282}$ In other words, a regulation is generally ineffectual until it is published. And second, the liaison officer responsible for publication is the locus of accountability on the agency side and can presumably be reprimanded if he or she fails to carry out the appropriate duties. ${ }^{283}$

The reasons recounted in Griswold's I934 article for the creation of the Federal Register system for domestic regulations apply with full force to executive agreements today. Executive agreements are as chaotic in their organization as regulations were in the r930s. And they, like regulations, have "the force and effect of law."284 Indeed, the ex ante congressional-executive agreements that form the bulk of our study are akin to regulations in the sense that they are executive directives with the force of law that are ostensibly authorized by congressional statute. When the administrative law transparency reforms of the I930s and I940s were undertaken, executive agreements were excluded from the reforms, and, over time, Congress instead established a piecemeal bifurcated system, described in Part I, of partial publication combined with (supposedly) comprehensive reporting to Congress. This system

$278 I d$. $\S \S$ I8.I, I8.3 (describing requirements and process for all documents to be published in the Federal Register). After receiving a final rule from an agency, OFR takes approximately three business days to publish it in the Federal Register. See I C.F.R. § I 7.2 (prescribing a regular schedule for filing for public inspection and publication); see also Lissa N. Snyders, When Does This Rule Go into Effect?, FED. REG.: OFF. OF THE FED. REG. BLOG, https://www.federalregister. gov/reader-aids/office-of-the-federal-register-blog/20 I5/o3/when-does-this-rule-go-into-effect

[https://perma.cc/2 YYK-NKMX]. Emergency schedules and deferred schedules are also available under certain circumstances. See I C.F.R. $\S \S$ I $7 \cdot 3-.7$ (describing criteria for emergency and deferred schedules and laying out schedules).

279 I C.F.R. § 5.Io; see also About the Federal Register, supra note 276.

280 See 5 U.S.C. $\$ 553(\mathrm{~d}) ; i d . \$ 553(\mathrm{~d})(\mathrm{I})-(3)$ (listing some exceptions). The process for "major" rules has an extra step. Before a major rule can go into effect, the agency must first submit the rule, along with a statement of its basis and purpose, a cost-benefit analysis, and "any other relevant information or requirements" to Congress. 5 U.S.C. § 80I(a)(I)(B)(iv); see id. § 80I(a)(I). Congress then has sixty days to pass a joint resolution rejecting the rule. See id. § $80 \mathrm{I}(\mathrm{a})(3)$. If it does not do so, then the rule goes into effect. See id.

281 See I C.F.R. § I 7.2.

2825 U.S.C. $\$ 55_{2}^{2}(\mathrm{a})(\mathrm{I})$ ("Except to the extent that a person has actual and timely notice of the terms thereof, a person may not in any manner be required to resort to, or be adversely affected by, a matter required to be published in the Federal Register and not so published.").

283 See Exec. Order No. I3,392 § 2(c)(ii), 70 Fed. Reg. 75,373, 75,374 (Dec. I9, 2005), reprinted in 5 U.S.C $\$ 55^{2}$ ("FOIA Public Liaisons shall report to the agency Chief FOIA Officer on their activities ....").

284 Griswold, supra note 270, at 198 (quoting Md. Cas. Co. v. United States, 25 I U.S. 342, 349 (I920)). 
has proven to be dysfunctional for reasons already explained, and Congress's efforts at piecemeal reform over the decades have not been successful.

The time has come to do for executive agreements what Congress did long ago for regulations: require reliable centralized collection of all agreements within the executive branch, and then prompt and comprehensive publication of all nonclassified ones. Below we first outline and make the case for these reforms. Then, in section III.A.2.c, we describe the structural changes that would be needed to effectuate the reforms.

(a) Internal Organization. - The case for mandating reliable centralized collection of the agreements akin to the centralized collection of regulations is simple: the executive branch needs to know what agreements its various agencies and departments have made with foreign governments so that it can meet its obligations, avoid inconsistent commitments, and learn from past agreements in negotiating future ones. This issue of internal bureaucratic organization arises prior to and is entirely independent of the question of what should be reported to Congress or made public.

As noted above, the government is currently not organized to meet this basic requirement of bureaucratic rationality related to executive agreements. State Department officials lack a comprehensive database of agreements, and they rely heavily on the more complete yet stillincomplete private HeinOnline database when researching concluded executive agreements. ${ }^{285}$ In other words, the State Department effectively outsources - without any checks for quality or accuracy — the compilation of U.S. agreements on which it relies. This crutch is growing weaker, however, because HeinOnline's ability to outpace the government declined after the death of Igor Kavass.

There is no conceivable justification for the federal government to have to rely on the incomplete database of a private paywalled commercial service to understand the scope of U.S. executive agreements. The HeinOnline database makes clear that a larger electronic database can be built. It also shows, more importantly, that this larger database serves important governmental needs. HeinOnline gets the vast majority of the agreements it publishes, and maybe all, from government sources. There is thus no reason why the government could not do at least what HeinOnline does, and probably significantly more, with the proper organization and resources.

285 It is not just the State Department that suffers from the lack of a comprehensive government database of U.S. agreements. As a Federal Advisory Committee on Status of Forces Agreements (SOFA) noted, the absence of such a database means that "different parts of the U.S. government disagree about whether [SOFA] agreements exist with a particular nation, whether agreements are still in force, and what their terms are." INT'L SEC. ADVISORY BD., REPORT ON STATUS OF FORCES AGREEMENTS 39 (2015), https://2009-20I 7.state.gov/documents/organization/236456.pdf [https://perma.cc/2 $\mathrm{M}_{59}-\mathrm{A}_{7} \mathrm{UJ}$. 
The executive branch already has an implicit duty to collect and organize executive agreements internally in order to meet its Case Act responsibilities, and it has failed in meeting this duty for decades. We propose stronger medicine below in section III.A.2.c.

(b) Comprehensive Duty to Publish. - The executive branch should be required to publicize all nonclassified executive agreements, just as it must publish all nonclassified regulations. (We also recommend publishing the legal authority on which each agreement is based - that proposal is outlined in section III.B.2 below.) This would be a change from current practice, which requires comprehensive reporting to Congress but only limited publication to the public.

The case for publishing all executive agreements rests on both noninstrumental and instrumental grounds. The main noninstrumental argument is good governance: the publicity of law is widely viewed as a core requirement of the rule of law, which demands special justification for secret law. ${ }^{286}$ The main instrumental argument is accountability: the executive branch must be scrutinized by outside institutions to ensure that it is carrying out its responsibilities to make sound executive agreements in the name of the United States in a lawful, prudent manner and without various forms of corruption, such as self-serving discrimination or self-dealing.

The need for such accountability by transparency is arguably greater for executive agreements than for domestic regulations since the former, in contrast to the latter, are typically not subject to judicial review. ${ }^{287}$ Moreover, executive agreements, unlike domestic regulations, give rise to binding international obligations, the violation of which can have consequences for groups not directly affected by the agreement itself, such as through countermeasures taken by other nations against the United States. ${ }^{288}$ The only potential checks on the executive agreement process are Congress and the public. But as we have shown, they are both in the dark about many of these agreements, and Congress has not displayed an interest in close scrutiny of the agreements. Moreover, interviews with congressional staffers revealed that one reason Congress does not more closely scrutinize the Case Act memos is that it lacks the

286 See, e.g., LON L. Fuller, The Morality OF LAW 39, 49-5 I (rev. ed. I969). See generally Jeremy Waldron, The Rule of Law, in STANFORD ENCYCLOPEDIA OF PHILOSOPHY (Edward N. Zalta ed., 2020), https://plato.stanford.edu/entries/rule-of-law [https://perma.cc/VJ8Z-HWEC].

287 Executive agreements are in many ways akin to regulations but are mostly excluded from the judicial review provisions of the APA because they "involve[] . . . a military or foreign affairs function.” 5 U.S.C. $\$ 553(\mathrm{a})(\mathrm{I})$. In addition, executive agreements concluded directly by the President are excluded because the APA has been interpreted not to apply to presidential actions. See Franklin v. Massachusetts, 505 U.S. 788, 800-0I (I992).

288 See Int'l Law Comm'n, Rep. on the Work of Its Fifty-Third Session, U.N. Doc. A/56/1o, at 26-30 (200I) (describing countermeasures permitted in response to internationally wrongful acts). 
resources to do so. ${ }^{289}$ Against this background, better publicity is essential to "fire-alarm" forms of accountability, in which journalists and interested groups can examine presidential behavior more closely than can Congress, and can identify and bring to light untoward executive behavior, which Congress can then closely examine and, if warranted, address. ${ }^{290}$ We cannot assess the magnitude of the change in congressional engagement that such accountability with the assistance of the public will bring. Only practice with the new transparency regime can tell us that.

It is true that executive agreements impact the primary behavior of citizens less often than do domestic regulations. Nevertheless, they often still govern primary behavior, mainly outside the United States, in determining what government officials and private citizens can and cannot do in areas ranging from air transport services, to health care for military members and their dependents, to civil aviation infrastructure, to science and technology cooperation, to investment incentives, to something as mundane as global postal services. In some instances, moreover, executive agreements may preempt state law. ${ }^{291}$ In addition, absent such transparency, Congress and the American people cannot fully observe executive branch action and thus cannot hold the President and other executive officials accountable in these important elements of the conduct of foreign policy and in the distribution of billions of dollars in aid, assistance, and other forms of government largesse. This form of accountability is especially important since, as noted, executive agreements are generally not subject to the Administrative Procedure Act ${ }^{292}$ (APA) or judicial review.

It is against this background that we propose to replace the executive branch's current duty to publish only a subset of international agreements with a duty to publish all nonclassified ones. A standard objection to a broad transparency mandate of this sort is that the monetary and diversion costs of searching and collecting information to be published can be wasteful compared to the ends achieved. ${ }^{293}$ But the executive branch is already supposed to be collecting this information to meet its Case Act obligations, and the collection and organization of this information is needed in order to conduct a coherent foreign policy. The additional cost of publication, after internal collection and organization, should be relatively small. This small cost is relevant because the orig-

289 See supra p. 665.

290 Mathew D. McCubbins \& Thomas Schwartz, Congressional Oversight Overlooked: Police Patrols Versus Fire Alarms, 28 AM. J. POL. SCI. I65, I66-67 (1984).

291 See Am. Ins. Ass'n v. Garamendi, 539 U.S. 396, 4 I6 (2003) ("Generally, then, valid executive agreements are fit to preempt state law, just as treaties are ....").

2925 U.S.C. $\$ \S 55 \mathrm{I}, 553-559,70 \mathrm{I}-706$.

293 See, e.g., Pozen, Freedom of Information Beyond the Freedom of Information Act, supra note 258 , at II $23-26$. 
inal justification for not requiring the publication of supposedly less important agreements was the extreme burden of publishing them all in hard copy. TIAS publication was years behind, and Congress made concessions to allow the State Department to catch up. In an age of digital storage and production, digital automation, and instantaneous transmittal, however, this justification no longer holds force.

One happy consequence of comprehensive publication is that a large portion of Case Act reporting duties can be eliminated. Comprehensive and timely publication of agreements renders superfluous the need for a parallel track of reporting to Congress. There should be one rule for nonclassified agreements: publication. Congress will get notice at the same time as the public.

There are, to be sure, potential downsides to a comprehensive publication duty. The duty may lead the executive branch not to make some agreements it otherwise would have made, or to make them on different terms, due to new political pressures that it anticipates as a result of ex post transparency. To the extent that some of these avoided or altered agreements might have been entirely proper and served U.S. interests (despite their unpopularity in certain circles), the transparency would be costly to U.S. foreign policy. By contrast, to the extent that the executive branch changes its practices to avoid scrutiny of bad agreements, however defined, or agreements based on poor information, or agreements that are unlawful or close to being so, transparency would be performing a useful function. It is very hard to know in advance what the aggregate effect of comprehensive transparency will be on this dimension. It is similarly hard to know whether more transparency will on balance empower ordinary citizens or special interests more. ${ }^{294}$

We cannot sort out these empirical questions without additional information. But that should not matter to the case for reform. Congress has long mandated, and the rule of law presumptively demands, that executive agreements be published. The exception to publication for a subset of supposedly unimportant executive agreements has never been justified on any ground related to foreign policy need or concern about interest-group activity. It has been justified solely on the basis of resource constraints - a justification that no longer makes sense in the digital age. And as noted, comprehensive publication will achieve a form of efficiency since it will eliminate the need for separate Case Act reporting to Congress for nonclassified agreements. Finally, to the extent that there are legitimate concerns about the negative consequences of heightened transparency in this area, the executive branch is in the best position to identify and articulate those concerns, and it presumably can make the case for any needed limitations on transparency when

$294 C f$. $i d$. at I I I2-I 7 (noting how powerful firms exploit FOIA). Notably, such powerful interests already may be more likely than the broader public to know about the unpublished agreements, so the change in scrutiny from these interests may be less than it otherwise might be. 
proposed reforms are considered by Congress. Subject to that caveat, we propose that laws made by executive agreement should be published just like laws made by administrative agencies.

(c) Implementing Reforms. - Most elements of the modern Federal Register system can be translated straightforwardly to international agreements. For example, every agency that makes agreements should be required to designate a liaison officer who is responsible for meeting the agency's reporting duties. And such agreements should be promptly published in the Federal Register or in a publication akin to the Federal Register. However, international agreements have characteristics that might require adjustment of three elements of the Federal Register system.

One important issue is whether the central repository for receiving and publishing the agreements should be the State Department, a new agency under the Archivist of the United States akin to the Office of the Federal Register, or the Office of the Federal Register itself. There is a strong argument to be made that these tasks should be the responsibility of a new agency under the Archivist or made part of the Office of the Federal Register's responsibilities. First, the State Department has failed at the tasks for decades. Second, the Archivist and Office of the Federal Register have extensive experience with publication tasks for domestic laws, regulations, proclamations, and the like, and have proven themselves rigorous, professional, and competent. Third, and relatedly, publication would almost certainly be more orderly and complete under the command of these relatively independent institutions, at least in the short to medium term.

Despite these points, we believe the task of publication should remain within the State Department, albeit in a component with significantly greater resources and authorities than at present. First, the State Department is where the expertise lies with respect to executive agreements. This is important for substantive tasks like distinguishing binding from nonbinding agreements. Expertise is also important in determining how best to organize the information. A key task of reform will be to organize executive agreements in an intelligent and searchable fashion, akin to regulations, by subject matter or by the legal authority that authorized them. ${ }^{295}$ Expertise is vital in performing these tasks.

Second, the State Department has an unavoidable duty, with no parallel in domestic regulations, of vetting the agreements (through the C-I 75 process) to ensure that they cohere and do not conflict with one another. This makes the State Department the natural entity for the

295 At a minimum, the duty to organize and publish executive agreements must include agreements entered into after the Federal Register-like system for agreements is established. Ideally, the State Department would also be required to include prereform executive agreements in the publicly searchable database, although this task is harder and would require significantly more resources. The funding restriction we propose on implementation of nonpublished agreements, see infra $\mathrm{p}$. 707 , should attach only to agreements concluded postreform. 
back-end tasks of collecting and publishing finalized agreements. And the Treaty Division within the Legal Adviser's Office is the natural entity within the State Department to be responsible for these tasks. Third, Congress has always wanted publication and reporting to be centralized in and performed by the State Department - which is, after all, the central diplomatic arm of the U.S. government. Yet the State Department has never been given adequate resources and adequate authority within the executive branch to do these tasks properly. It should be given these things.

The last reason for vesting the responsibility with the State Department is that a single agency should have primary responsibility for overseeing and managing our international relations. The obvious agency for those purposes is the Department of State. Our study reveals that the Department often does not receive the cooperation from other agencies that it needs in order to meet its responsibilities. Both late reporting and underreporting are driven in no small part by the failure of other executive branch agencies to communicate with State. This is a problem not only for reporting and publication but also for international diplomacy. If no single agency in the U.S. government knows all the agreements concluded between the United States and the rest of the world, it is hard to maintain consistency and coherence among U.S. agreements. ${ }^{296}$ One goal of the $\mathrm{C}-\mathrm{I} 75$ process was to force coordination through the State Department. By all appearances, that process is not working as well as it should. Rather than abandon it, Congress should reaffirm and reinforce it with real consequences for failures to coordinate, as described below.

A separate issue concerns when the concluded agreement must be published. The rule for Federal Register publication is thirty days before the regulation enters into force. As noted in Part I, under current law most international agreements must be transmitted to Congress no later than sixty days after they enter into force, and published within I 80 days of entering into force. So the questions are whether the general publication requirement should be ex ante (like regulations) or ex post (like agreements today), and what the time period for publication should be.

As noted in the Introduction, before INS v. Chadha, it was common for Congress and the public to receive advance notice of agreements. Today, however, ex post publication for nonclassified agreements is the norm. This more limited obligation has long been accepted by the executive branch and imposes few if any costs on the process of negotiating and completing agreements. Ex post publication does not interfere with the confidentiality of negotiations, and it can usefully expose bad agreements after the fact and thereby give the executive branch an incentive

296 It also likely makes it difficult for the United States to comply with its international legal duty to register with the United Nations "[e]very treaty and every international agreement . . . as soon as possible." U.N. Charter art. IO2, II I. 
not to make bad agreements in the first place. These are the aims of transparency. Extending such ex post publicity to a class of less important agreements is unlikely to hamper the executive branch in making agreements as part of the conduct of U.S. foreign policy.

Congress almost certainly has the constitutional authority to impose earlier publication requirements. Article II treaties, after all, must be published, debated, and consented to prior to ratification. The same is true of ex post congressional-executive agreements. Moreover, as noted in Part I, Congress sometimes requires that certain agreements or classes of agreement be disclosed to Congress (and the public) for a period before the agreement comes into force so that Congress can scrutinize and push back on the agreement if it sees fit. These are entirely legitimate mechanisms of transparency and increased accountability to Congress. But they come at the expense of the efficiency that Congress has long sought for many congressional-executive agreements. They elongate the agreement-making process and make it harder for the President in many instances to negotiate particular agreements since he or she must in effect negotiate with two different audiences - first the foreign government, and then Congress.

Congress has full discretion to change the allocation of publication requirements before and after an agreement comes into force. But it appears to be generally satisfied with ex post reporting, and it has shown every ability to impose various forms of ex ante reporting when it wishes. It may come to a different view in the face of a more robust transparency regime. For now, there is little evidence that Congress is dissatisfied with its presumption that the vast majority of agreements can receive adequate accountability through ex post publication. And as noted above, a better publication system will only improve the accountability provided by ex post publication. For these reasons, we believe that ex post publication can achieve the transparency goals outlined here. ${ }^{297}$

As for timing, we propose that the executive branch should have sixty days to publish after the agreement enters into force. This has been the amount of time that Congress has for decades prescribed for State Department reports under the Case Act, and it is more forgiving than the advance-publication requirement for regulations. We are cognizant of the potential costs of strict deadlines in related contexts. ${ }^{298}$ But

\footnotetext{
297 One of us has advocated an Administrative Procedure Act-type regime for international law - which would involve reforms to the process for making executive agreements based on the APA's domestic rulemaking process, but with modifications to account for the international nature of the agreements. See Hathaway, supra note 8, at 242-53. That proposal called for ex ante publication, with a period for notice and comment. See id. at 243-49. This new proposal is not intended to suggest that the author of that piece has shifted positions, but simply that there are other possible ways to achieve many of the same goals.

298 See Jacob E. Gersen \& Anne Joseph O'Connell, Deadlines in Administrative Law, I56 U. PA. L. REV. 923 , 929 (2008).
} 
given the relatively long sixty-day window, modern communication and organization technologies, and the importance of the issue, the executive branch should be able to publish to the world the nonclassified agreements that it is already supposed to have in hand within this period.

The final issue here concerns the proper enforcement mechanism. The federal regulation process is enforced primarily by making the regulations nonapplicable until published. This is a difficult rule to impose on international agreements generally, many of which come into effect upon signature. For that reason, and because there is such a long history of noncompliance with reporting and publication requirements for executive agreements, we propose that Congress make permanent the scheme that prevailed from I987-1989 and 2005-2007: Congress should specify that no funds are available to implement any agreement until it is transmitted - first to the Department of State and, then, through the Department of State to Congress. ${ }^{299}$ If Congress adopts the comprehensive publication recommendations we propose, and thus eliminates the separate requirement of transmittal to Congress, then Congress should make funding for implementation of every nonclassified agreement conditional on its publication.

$* * *$

The reforms we have proposed thus far include an extensive reorganization of the executive branch to ensure comprehensive centralized collection of executive agreements, comprehensive publication of executive agreements, and, to the extent possible, collection and publication of past agreements in accordance with this new regime. These reforms are consistent with the known aims of the Case Act and its amendments and are especially appropriate in our digital era. Many of them - especially the internal reforms and increased funding - are also sought by the State Department. However, these reforms would entail a major undertaking that would require significant appropriations and other support from Congress as well as significant organizational efforts by the State Department or the National Archivist. Congress should provide adequate resources but also impose a deadline.

299 See supra pp. 653-54. There are indications in the 200 I Congressional Research Service study that the funding restriction in the I980s may have helped improve reporting. See CRS TREATY STUDY, supra note I4, at 226 tbl.X-I (showing a drop in late reporting from the early '8os to the late '8os). In addition, the information in the Case Act Reports database that the State Department maintained between 2006 and 2013 suggests that the reports were more timely during the 20052007 funding-cutoff period than they have been since that time. (In 2006, twenty-one percent of the reports were late, and in 2007 , thirty-four percent were late - compared to roughly forty percent in later years.) 
3. Political Commitments. - The current regime of publication and reporting for international agreements excludes nonbinding commitments, also known as "political commitments." 300 This is true even though political commitments have become an increasingly important component of the executive branch's agreement-making practice. For example, the Obama Administration used nonbinding provisions in both the Iran nuclear deal and the Paris climate change agreement without seeking congressional approval, and the Trump Administration did the same in signing the U.S.-Mexico Joint Declaration and Supplementary Agreement to "address the current situation at the southern border of the United States."301 More broadly, political commitments govern dayto-day international regulatory cooperation between federal agencies and foreign counterparts. ${ }^{302}$

Even back in its 200I study of treaties, the Congressional Research Service noted that the lack of reporting of nonbinding political commitments "could represent a large loophole" in the Case Act regime. ${ }^{303}$ And if the reporting requirements for binding agreements are made more effective, it is possible that the executive branch or agencies within it could be even more motivated to circumvent those rules by concluding the agreements instead as "nonbinding" agreements not subject to the reporting rules.

The same basic arguments for requiring transparency of executive agreements apply to political commitments - but not all political commitments, in our view. The main reason is that the category of political commitments is not nearly as sharp as the category of binding executive agreements, since at one end of the spectrum all diplomatic speech that entails pledges can be seen as political commitments. At the same time, political commitments, especially in the regulatory context, can have large impacts on the economy and foreign policy, and on the primary behavior of domestic actors, just as domestic regulations do. ${ }^{304}$ The

300 See 22 C.F.R. $\S$ I8I.2(a)(I) (2019) ("The parties must intend their undertaking to be legally binding, and not merely of political or personal effect.”). But see Ryan Harrington, A Remedy for Congressional Exclusion from Contemporary International Agreement Making, I I8 W. VA. L. REV. I 2 I I, I 243 (20I6) ("There is no reason why, textually, the Case Act should not apply to political commitments, which would require modification of the C.F.R. provisions, not of the U.S. Code.").

301 See Bradley \& Goldsmith, supra note 4, at I242, I248-52; Joint Declaration and Supplementary Agreement on Migration, Mex.-U.S., June 7, 2019, T.I.A.S. No. I9-607.

302 See U.S. GOV'T ACCOUNTABILITY OFF., GAO-I 3-588, INTERNATIONAL REgulatory COOPERATION IO-I I (20I3), https://www.gao.gov/assets/66o/656488.pdf [https://perma.cc/G3NM$\left.\mathrm{W}_{2} \mathrm{QA}\right]$.

303 CRS TREATY STUDY, supra note $\mathrm{I} 4$, at $23 \mathrm{I}$.

304 For example, the United States and the European Union coordinate enforcement of their antitrust, securities, and banking laws pursuant to nonbinding political commitments. See, e.g., Best Practices on Cooperation in Merger Investigations, E.U.-U.S., Oct. I4, 20I I, https://www.ftc.gov/system/files/I I Ior4eumerger.pdf [https://perma.cc/8XFC-6P8V]; Framework Cooperation Agreement, E.U.-U.S., Sept. I8-27, 20I7, https://www.sec.gov/about/offices/oia/ 
public should thus have access to important political commitments in an organized and searchable fashion on the same terms as it does in the reformed executive agreement process. ${ }^{305}$

Congressional staffers whom we interviewed emphasized the problem of accountability for political commitments and stated that reforms to increase the transparency of executive agreements should be coupled with reforms to increase the transparency of political commitments. ${ }^{306}$ Otherwise, they feared, greater transparency for binding executive agreements could create incentives to shift toward even less transparent nonbinding political agreements. To prevent this shift - which would lead to less, rather than more, transparency - from occurring, it is important to anticipate it and create disincentives for such a shift.

The challenge is how to define the category of nonbinding political commitments. ${ }^{307}$ On the one hand, the definition should not be so broad as to sweep in, for example, agreements to conduct future meetings. On the other hand, it should not be so narrow as to allow agreements that are effectively the same as binding executive agreements to be concluded by executive agencies with almost no oversight from Congress - or even the State Department itself.

One possibility is to describe a list of types of commitments - such as ones that create a likely impression of an obligation to take actions not solely within the scope and authority of the current presidential administration (for example, actions that would be taken after the conclusion of the current presidential term) or that require congressional action to implement - that must be centrally collected and published. A second possibility is to create a statutory duty to collect and publish all political commitments that are comparable to past binding executive agreements in their scope and subject matter (where the agreement is substantially similar but uses slight changes of phrase to make it not

oia_bilateral/eba-framework-cooperation-arrangement-sep I 7.pdf $\quad$ [https://perma.cc/NM8Z-7 $\left.\mathrm{UJ}_{4}\right]$; Memorandum of Understanding Concerning Consultation, Cooperation, and the Exchange of Information Related to the Supervision of Cross-Border Regulated Entities, E.U.-U.S., Mar. I4-I5, 20I 2 , https://www.sec.gov/about/offices/oia/oia_bilateral/esma-mou.pdf [https://perma.cc/M2DU-LD83]. See generally U.S. GOV'T ACCOUNTABILITY OFF., supra note 302.

305 See also Duncan B. Hollis \& Joshua J. Newcomer, "Political" Commitments and the Constitution, 49 VA. J. INT'L L. 507, 575 (2009) (“Congress may facilitate (or demand) the disclosure of political commitments, and the President would have a corresponding obligation to provide Congress with such data.").

306 Telephone Interview by Oona Hathaway with Current U.S. Government Lawyer (May 27 , 2020).

307 It may be useful to study how other constitutional democracies that require legislative involvement in treaty-making have handled this issue. For example, in 2014, Spain enacted a new Treaties Act that, among other things, requires nonbinding agreements to be centrally collected by the Ministry of Foreign Affairs and maintained in a public registry. See Carlos Espósito, Spanish Foreign Relations Law and the Process for Making Treaties and Other International Agreements,

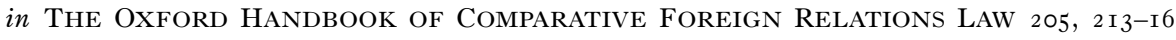
(Curtis A. Bradley ed., 2019). 
expressly binding). A third possibility is to require the executive branch to collect and publish political commitments meeting a general standard, such as "significant" or "important." 308 This less precise standard may have the disadvantage of being subject to convenient interpretation by the executive branch, but it has the distinct advantage of sweeping into publication novel forms of important political commitments that fall outside the more rigid categories. This approach could give agencies notice that they need to figure out and report what counts as important, and will be penalized by Congress and the public if they are later deemed wrong. ${ }^{309}$

\section{B. Ensuring Legality}

We now turn to the legality of the agreements reported under the Case Act. As noted above, regulations implementing the Case Act require that all reported agreements be accompanied by a cover memo that includes a "precise citation of legal authority." Our analysis of thousands of these memos reveals that, for a significant number of executive agreements, the executive branch's legal authority to conclude the agreements is at best uncertain and sometimes highly questionable. It is not our aim in this section, however, to resolve the legal questions implicated by the memos. As explained in Part I, there are many uncertainties about the legal basis for executive agreements that we cannot resolve in this Article. Instead, our argument here is simply that there should be greater transparency concerning what the executive branch is doing and claiming so that Congress and the interested public can better evaluate these legal issues.

I. Legality Issues that Emerge from the Data. - The thousands of cover memos that we obtained provide insights into how broadly the executive branch has been interpreting its authority to conclude agreements. Before considering the implications of the data, however, a caveat is in order. As discussed in Part II, the "legal authority" section in the cover memos is not typically written by lawyers and does not necessarily reflect the full or considered judgment of the lawyers in the State Department about the legal basis for the agreement. The cited legal authorities thus might not be the best, or the most accurate, statement of the actual legal authorities for making the agreement. This problem infects the entire corpus of Case Act cover memos that are supposed to inform Congress about the legal bases for every international agreement.

These citations of legal authority are nevertheless important. They are very likely drawn from the internal C-I 75 legal memos, which are

\footnotetext{
308 See, e.g., 50 U.S.C. $\S 3092$ (a) (requiring the executive branch to keep "intelligence committees fully and currently informed" of noncovert U.S. intelligence activities, including "significant anticipated intelligence activity").

309 For how this approch has worked in the intelligence reporting context, see JACK GOLDSMITH, POWER AND CONSTRAINT 88-9I (20I2).
} 
prepared by State Department lawyers. And whatever their quality, the citations are official communications from the executive branch to Congress, pursuant to regulation, of the legal authority for executive agreements. If they are unreliable, that is itself an important fact in evaluating the transparency regime governing executive agreements.

(a) Executive Agreements+. - As discussed in Part II, approximately seven percent of the cover memos we obtained cite only Article II of the Constitution. These are the agreements that the executive branch appears to believe are sole executive agreements. The remaining ninety-three percent of the cover memos invoke statutory or other nonconstitutional authority - sometimes with, and sometimes without, Article II as well. This finding seems to confirm, consistent with conventional wisdom, that the sole executive agreement power is narrow in scope.

The database also allowed us to examine the Executive Agreements+ theory by examining the cover memos for the agreements cited by Professors Bodansky and Spiro as examples of this theory. ${ }^{310}$ We found for each of these agreements that the government sought to justify them not on the basis of Article II alone or an Executive Agreements+ theory, but rather on the basis of congressional (or treaty-based) authorization. ${ }^{311}$ For example, Bodansky and Spiro cite the Paris Climate Change Agreement as an Executive Agreement+. ${ }^{312}$ The agreement became effective too late to be included in our database, but we separately obtained a copy of the Case Act cover memo for the agreement. ${ }^{313}$ Far from claiming mere consistency with domestic law, the memorandum cites five bases of "Legal Authority," including the United Nations Framework Convention on Climate Change, which by itself probably suffices to authorize the agreement. ${ }^{314}$ Similarly, the environmental and tax-related agreements cited by Bodansky and Spiro ${ }^{315}$ are ones where the government claimed several bases of statutory legal authority. ${ }^{316}$

310 See Bodansky \& Spiro, supra note 56 , at 887,889 .

311 There is no cover memo for the Anti-counterfeiting Trade Agreement, nor was there a C-I 75 memorandum prepared for it. See Letter from Sheryl L. Walter, Dir., Off. of Info. Programs \& Servs., U.S. Dep't of State, to Mark Rumold, Elec. Frontier Found. I (May I, 20I2), https://www.eff.org/files/filenode/acta_foia_response_5-20I2.pdf [https://perma.cc/582Z-7J6B].

312 See Bodansky \& Spiro, supra note 56, at 886-87.

313 See Letter from Michael J. Mattler, Assistant Legal Adviser, Off. of Treaty Affs., U.S. Dep't of State, to Senator Bob Corker, Chairman, Senate Comm. on Foreign Rels. (Dec. 22, 20I6) (on file with the Harvard Law School Library) (providing, inter alia, cover memo for Paris Agreement).

314 For an explanation of why the United Nations Framework Convention on Climate Change probably suffices to authorize the agreement, see Bradley \& Goldsmith, supra note 4, at I268-69.

315 See Bodansky \& Spiro, supra note 56, at 889, 905-06, 91 I-I4.

316 For example, Bodansky and Spiro mention several international agreements that implement the Foreign Account Tax Compliance Act (FATCA). See id. at 9r2-r3. However, the government did not argue that these agreements were unauthorized by statute or merely "consistent" with FATCA or any other law. To the contrary, it cited numerous legal bases for the agreements, see id., 
Bodansky and Spiro also cite the Minamata Convention on Mercury, a multinational agreement that regulates the production, use, and disposal of mercury. ${ }^{317}$ The government publicly explained that the agreement "complements domestic measures by addressing the transnational nature of the problem" and noted that the United States "can implement Convention obligations under existing legislative and regulatory authority,"318 language that sounds like it might reflect the Executive Agreements + theory. Although the agreement falls outside the scope of our FOIA request, ${ }^{319}$ we managed to obtain the Case Act cover memo for it as well. ${ }^{320}$ While many of the constitutional and statutory bases cited in the memo as legal authority for the agreement do not plausibly authorize the agreement, one cited statute, the National Environmental Policy Act of $1969,{ }^{321}$ provides at least plausible authorization. The statute authorizes federal agencies to administer the Act's policies and directs them to provide "support to initiatives, resolutions, and programs designed to maximize international cooperation in anticipating and preventing a decline in the quality of mankind's world environment." 322 This statute is cited in some of the cover memos in our database, and we coded it a 4.

In sum, we see no indication in the cover memos that the executive branch was asserting a claim that it has the authority to conclude executive agreements as long as they are consistent with domestic law. To the contrary, the ostensible examples of Executive Agreements+ for which we have memos all cite statutes as "legal authority" and include at least one citation to a statute or treaty that we view as at least plausible authorization for the agreement. As a result, it would be very difficult to argue that, by receiving and failing to challenge these memos, Congress has somehow acquiesced in the Executive Agreements+ claim.

one of which, 26 U.S.C. $\S$ I $47 \mathrm{I}$, we coded as a 3 . The same is true of the one environmental agreement that Bodansky and Spiro cite for which we have a cover memo in the database. See Bodansky \& Spiro, supra note 56, at 906; Protocol to the 1979 Convention on Long-Range Transboundary Air Pollution to Abate Acidification, Eutrophication, and Ground-Level Ozone, opened for signature Dec. I, I999, T.I.A.S. No. I3,073. The cover memo for this agreement cites three bases of authority, including one, 42 U.S.C. $\$ 432$ I et seq., which we coded as a 4.

317 Bodansky \& Spiro, supra note 56, at 910.

318 Press Release, U.S. Dep't of State, United States Joins Minamata Convention on Mercury (Nov. 6, 20I3), https://2009-20I 7.state.gov/r/pa/prs/ps/20I3/I I/2 I $7295 . h t m$ [https://perma.cc/TQ 3 VBDQ3].

319 The Minamata Convention was signed by the executive branch on November 6, 2013. See $i d$. The agreement did not formally enter into force until August I6, 20 I 7, however, see Minamata Convention on Mercury, adopted Oct. I0, 20I3, T.I.A.S. No. I7-8I6, and it was not reported to Congress until September 27,2017 , see Letter from Michael J. Mattler, Assistant Legal Adviser, Off. of Treaty Affs., U.S. Dep't of State, to Senator Bob Corker, Chairman, Senate Comm. on Foreign Rels. (Sept. 27, 2017) (on file with the Harvard Law School Library).

320 See Letter from Michael J. Mattler to Senator Bob Corker, supra note 3 I 9.

32142 U.S.C. $\$ \S 432 \mathrm{I}-4347$.

322 See id. $\$ 4332(2)(\mathrm{F})$. 
(b) Ex Ante Congressional-Executive Agreements. - As noted above, approximately ninety-three percent of the memos in our database cite one or more statutes or other nonconstitutional authorities as a source of authority. As explained in Part II, we coded cited authorities listed in these memos into one of five categories on a spectrum ranging from express support for executive branch agreement making (category I) to no such support (category 5). Determining whether the cited authorities genuinely authorize the executive branch to conclude the agreement presents difficult interpretive questions.

As an initial matter, when the executive branch cited one or more nonconstitutional sources of authority for an executive agreement, it also commonly cited to the Constitution, usually to Article II. Many of these references to the Constitution appear to be included in the cover memos reflexively rather than in a considered manner as an actual basis for the agreement. For example, about sixty-eight percent of agreements that cite a nonconstitutional authority coded I also cite the Constitution. In these cases, a citation to the Constitution is unnecessary since the other citation does all of the necessary authorizing work.

It is difficult to draw firm general conclusions about the relevance of Article II for the agreements for which Article II is cited alongside statutes in categories 2-4. Although the constitutional power to conclude sole executive agreements is probably narrow, it is possible that Article II can in some instances be combined with a statute in a way that produces more overall authority than either would provide alone. Among other things, courts tend to be more willing to find implicit statutory authority in areas in which the President has some independent constitutional authority. ${ }^{323}$

Even putting this complication aside, interpreting the statutes that are cited is challenging, especially in categories $2-4$. The authorizations in these categories provide some indication of congressional intent to engage in global cooperation but no express authority to conclude an agreement. The difficult legal question here, as noted in section I.A.2, comes in determining whether these authorities should be interpreted to implicitly authorize executive agreements. ${ }^{324}$ The authorities that the government relied on in practice make plain how difficult this question can be.

In category 2 , it is unclear whether an authorization to negotiate an agreement should count as authority to conclude one. An authorization to negotiate, combined with an ex post congressional approval requirement, seems clearly not to be an authorization to the executive to conclude an agreement. So it is unclear why silence on executive authority to conclude an agreement should be construed in favor of authority to conclude one, as opposed to mere authority to negotiate, as the plain

323 See Bradley \& Goldsmith, supra note 4, at I 264.

324 See supra section I.A.2, pp. 64I-43. 
text of these statutes indicates. Authorizations in categories 3 and 4 are similarly uncertain. When Congress authorizes an executive branch agency to furnish assistance or make economic arrangements with a foreign country, or to engage in international cooperation or establish a program with them, it is not obviously authorizing the making of binding international agreements; it might be, but one needs to know more.

An additional complicating factor here is that many of the "legal authority" sections in the cover memos contain multiple legal citations sometimes to statutes alone, often to statutes and Article II - without further explanation. The practice of supporting the legality of agreements with multiple authorizations is practically unheard of in the context of domestic authorization for administrative action. ${ }^{325}$ Executive orders, however, sometimes cite multiple sources of authority, including Article II and statutes. ${ }^{326}$ Supreme Court decisions addressing how to approach multiple authorizations in this latter context provide no general guidance. ${ }^{327}$

The multiple-citation practice presents few if any interpretive problems when at least one of the cited authorities provides express authorization. To take one example, the cover memo for the 2004 Acquisition and Cross-Servicing Agreement between the United States and Afghanistan cites as legal authority "[t]he President's Constitutional authority as Chief Executive to conduct the foreign relations of the United States, as well as his authority as Commander-in-Chief of the Armed Forces, (Article II, Sections I and 2); NATO Mutual Support Act of I979, as amended, Io U.S.C. 2342(a) and (b)." The NATO Mutual Support Act of $1979^{328}$ is coded I, because it provides that the "Secretary of Defense may enter into an agreement [with] ... [t]he government of a North Atlantic Treaty Organization country"329 or a country not a member of NATO but that has been designated by the Secretary of Defense and properly noticed to Congress. ${ }^{330}$ Of the 5,689 cover memos

325 While we cannot rule out the possibility, we have been unable to locate a single instance in which an agency tried to rely on multiple statutes in support of its authority to enact a regulation.

326 See, e.g., Exec. Order No. I2,333, 3 C.F.R. 200, 200 ( 1982 ), reprinted as amended in 50 U.S.C. $\S 300$ I note.

327 In Chrysler Corp. v. Brown, 44I U.S. 28I (1979), the Supreme Court, in the context of an executive order implementing corporate disclosures related to affirmative action, interpreted several ostensible congressional bases for the order seriatim and concluded that none authorized it. See id. at 304-08. And in Old Dominion Branch No. 496 v. Austin, 418 U.S. 264 (1974), the Court stated with little analysis that an executive order governing labor relations in federal employment both had "express statutory authorization" and was a "reasonable exercise of the President's responsibility for the efficient operation of the Executive Branch." Id. at 273 n.5.

328 Io U.S.C. $\S \S 234 \mathrm{I}-2348,2350$.

329 Id. $\$ 2342(\mathrm{a})(\mathrm{I})$.

330 Id. The required notification process for a non-NATO country was presumably completed in this case, because of the high visibility of the U.S. commitments in Afghanistan, but this example 
we analyzed, $44.31 \%$ are supported by an authorization in category I. ${ }^{331}$ In these cases, the agreement probably had adequate authorization (assuming the agreement actually fell within the scope of the authorization - which we did not assess), regardless of what additional authority the other statutes might have provided.

For the $55.69 \%$ of agreements that lack a citation to an authority in category I, however, the multiple-citation issue presents many problems, and the legality of the agreements is much less certain. One problem, noted above, is that none of the cited authorities in categories 2-5 contains an overt authorization to make an executive agreement. So the authorization to make the agreement exists, if at all, because the cited authority, combined with Article II, should through interpretation be deemed to authorize the agreement. One must presumably consider all of the statutory authorizations in support of an agreement, plus the effect of Article II when indicated, as well as the possible aggregative effect of these provisions, on legality. But courts have rarely considered the impact of multiple authorizations on a single executive branch act, and thus have provided few interpretive guideposts. The interpretive task is made all the more difficult because the underlying statutory authorizations are differently worded, arise in different historical and subject-matter contexts, and combine in different ways that might have differing aggregative effects on the legality of particular agreements.

The agreements that have the most questionable claim of legal authority are those for which the highest-coded cited authority was in category 5 - something true for about seventeen percent of the agreements covered by our database. ${ }^{332}$ For these agreements, the executive branch does not appear to be claiming that the agreement is a sole executive agreement (because it is citing a nonconstitutional authority), and yet the authority that it is citing in support of the agreement does not plausibly appear to be conveying any authority to conclude an agreement.

These various uncertainties are compounded by the kitchen-sink and nonspecific way that the executive branch reports legal authority to Congress. Moreover, neither the American people, nor the few experts who could assess the problem, have ever had access to the documents that we are analyzing. All of these considerations inform our reform proposals, to which we now turn.

2. Reform Proposals. - It is not our aim in this Article to draw conclusions about the legality or illegality of the executive agreements in our database. Instead, our goal is to bring to light the ways in which legal authority has been invoked in support of executive agreements for much of the past three decades. Our reform proposals are similarly

helps illustrate why we cannot be confident that an authority actually provides support for the agreement for which it is cited, even if that authority is coded $\mathrm{I}$.

331 See supra Table 4, p. 685

332 See supra Table 4, p. 685. 
aimed at bringing greater transparency to what the executive branch is doing and claiming with respect to executive agreements so that Congress and the interested public can better evaluate the relevant legal issues. To achieve such transparency, we propose several reforms.

First, in addition to publishing all agreements, the executive branch should be required to publish the legal authority for all agreements. This has been a requirement for administrative regulations since the dawn of the APA. ${ }^{33}$ The reasons for this requirement in the regulatory context are (I) to make judicial review more efficient, (2) to give full notice to the public, and (3) to ensure more careful deliberation on the part of the issuing agency or department. ${ }^{334}$ Reasons (2) and (3) apply straightforwardly to executive agreements. Reason (I) does not apply here, since there is typically little judicial review of executive agreements. But the lack of judicial review in this context only heightens the importance of reasons (2) and (3). In the absence of judicial review, publicity about legal basis is even more important to ensure that the government is careful and that the public can see what it is doing and hold it accountable.

Second, Congress should act to redress the executive branch's practice of including irrelevant or barely relevant authorities in a "kitchensink" fashion along with more relevant authorities. This practice, as we have shown, makes it enormously difficult to assess the legality of an agreement. This practice is so common that it seems likely that the executive branch is using the kitchen-sink approach as a substitute for analysis or in an effort to evade scrutiny.

We therefore propose that, for each agreement, the executive branch should be required to do one of two things. When Article II alone is

\footnotetext{
333 See Administrative Procedure Act, ch. 324, § 4, 60 Stat. 237, 238-39 (I946) (codified as amended at 5 U.S.C. $\S 553$ ). Under the current APA, the requirement derives from 5 U.S.C. $\S 553$ (b), which requires that a general notice of proposed rulemaking "shall be published in the Federal Register" and "shall include ... reference to the legal authority under which the rule is proposed," $i d$., and 5 U.S.C. $§ 553(\mathrm{c})$, which requires agencies to incorporate "a concise general statement of . . . basis and purpose" into the final rule, $i d$. The phrase "basis and purpose" in $\S 553$ (c) has long been understood to incorporate by reference the requirement to publish legal authority from $\S 553$ (b)(2). See Global Van Lines, Inc. v. Interstate Com. Comm'n, 7I4 F.2d I 290 , I 298 (5th Cir. I983); see also I C.F.R. § 2 I.40 (2020) (requiring citation of legal authority for documents "subject to codification").

334 On judicial review, see DeP'T OF Just., FINAL REPORT OF THE ATTORNEy GENERAL'S Committee on Administrative Procedure i ig (I94I) (noting that judicial review demands that agencies be required "to demonstrate that they come rationally within the statutory authorization"); Am. Standard, Inc. v. United States, 602 F.2d 256, 269 (Ct. Cl. I 979) ("The purpose of requiring a statement of the basis and purpose is to enable courts, which have the duty to exercise review, to be aware of the legal and factual framework underlying the agency's action." (emphasis added)). On public notice, see S. REP. NO. 79-752, at 200 (I945) ("Agency notice must be sufficient to fairly apprise interested parties of the issues involved, so that they may present responsive data or argument relating thereto.”). On ensuring careful deliberation, see Texaco, Inc. v. Fed. Power Comm'n, 4I 2 F.2d 740, 744 (3d Cir. I 969) (rulemaking provisions of $§ 553$ enable "the agency promulgating the rule to educate itself before establishing rules and procedures which have a substantial impact on those regulated").
} 
being relied upon, the agreement should be labeled a "sole executive agreement" and only Article II should be cited. For any agreement that is not claimed to be a sole executive agreement, Congress should require the executive branch to list one statute or treaty on which it primarily relies. If it cites any additional authority - statute, treaty, or Article II - it should be required to explain concretely the authority's relevance - that is, what it adds to the primary statutory or treaty authorization, and why. This approach acknowledges that some agreements can potentially be supported by a number of different authorizations, including an Article I source and an Article II source in combination. But it will discourage the inclusion of irrelevant authorities and will discipline the government to more closely focus on the proper legal basis for agreements. It would also make it easier for observers to assess and, where warranted, critique - the legal basis for agreements.

Third, the Legal Adviser should be required to personally warrant, in individual certifications to Congress, that each agreement is lawful. Congress often requires such certifications from senior officials when it wants to incentivize greater attention to a matter, especially when ordinary judicial review is lacking. For example, beginning in I99I, Congress prohibited the President from engaging in covert action without a finding by the President that contains many elements. ${ }^{335}$ Congress specified that such a finding "may not authorize any action that would violate the Constitution or any statute of the United States," which in practice means that the President must ensure that the covert action is not unlawful. ${ }^{336}$ Similarly, for a traditional Title I Foreign Intelligence Surveillance Act $^{337}$ (FISA) application, the Attorney General must certify various matters to the Foreign Intelligence Surveillance Court to ensure compliance with Fourth Amendment and other privacy concerns. ${ }^{338}$ Such certification requirements are obviously no panacea, but they do promote closer attention to the legality of the actions in question as well as greater accountability. ${ }^{339}$

All three of these proposals could be accomplished in connection with a simple overarching reform: a requirement that the cover memos,

\footnotetext{
335 50 U.S.C. $\$ 3093$ (a); see Bradley \& Goldsmith, supra note 4, at I $276-77$.

336 50 U.S.C. $\$ 3093(\mathrm{a})(5)$.

337 Foreign Intelligence Surveillance Act of 1978 , Pub. L. No. 95-5 I I, 92 Stat. I 783 (codified as amended in scattered sections of 50 U.S.C.).

338 See 50 U.S.C. § I 804 (a); H.R. REP. No. 95-I 283 , pt. I, at I 5, 23, 54, 73 (I 978 ).

339 On covert action, see GoldSMITH, supra note 309, at 89-90. On FISA, see H.R. REP. No. 95-I 283 , pt. I, at 54, 73. See also I8 U.S.C. $\$ 2332$ (d) (requiring Attorney General to make certification before prosecuting certain crimes).
} 
like the ones we obtained through FOIA, be published. ${ }^{340}$ Under a publication scheme, the cover memos could be required to include a determination of whether the agreement is a sole executive agreement or a congressional-executive agreement, and, if it is a congressional-executive agreement, the primary legal authority. The cover memo could also be required to include a personal certification by the Legal Adviser. Creating a publication system for the cover memos (ideally in conjunction with publication of all nonclassified executive agreements, as discussed above) would ensure greater transparency and accountability. It would also, we expect, encourage more careful attention to ensuring that executive agreements rest on adequate legal authority.

\section{Reforms that Would Not Require Legislation}

The reform proposals discussed above would require new legislation. One advantage of implementing reforms through legislation is that they are likely to be more robust because they will involve binding legal duties. Legislation will also outlast any change in personnel on congressional committees. But there are also obvious disadvantages of relying on legislation for reform: Legislation requires members of Congress to act collectively, something that has become especially difficult with the rise of hyperpartisanship, and it generally requires the cooperation of the executive branch. If a statute is likely to provoke an executive veto, it is extraordinarily difficult to enact it, as it is practically impossible to muster the majorities necessary to overcome a presidential veto.

There are, fortunately, some reforms that the congressional committees that currently receive Case Act reports could carry out themselves without any new legislation. First, either the House Foreign Affairs Committee or the Senate Foreign Relations Committee could simply publish the unclassified cover memos and agreements that they receive through Case Act reporting. There is no legal prohibition on making these government documents public. Congress already maintains its own online database for Article II treaties, ${ }^{341}$ and it could easily add a similar database for executive agreements reported under the Case Act. When publishing the agreements, it could also include the cover memos. As discussed above, such publication would itself substantially heighten transparency in this area. The Committees already go to the trouble of scanning the Case Act submissions and circulating them internally in

\footnotetext{
340 A more ambitious approach would be to adopt a rule of construction that no statute or provision in a statute may be construed to provide authority for an international agreement or arrangement absent an explicit and specific statement of authority (effectively ruling out reliance on statutes we have coded 2-5). Another more ambitious proposal would specify that no funds would be available to implement any congressional-executive agreement that relies on anything other than express statutory authority. But such measures would require Congress to conclude that only express statutory authority provides sufficient legal basis for agreements - a conclusion it has yet to embrace.

341 About Treaty Documents, CONGRESS.GOV, https://www.congress.gov/treaties/about [https:// perma.cc/SF 2 F-ZVQQ].
} 
electronic form. It is not a significant additional step to make those electronic files public.

Second, the congressional committees could request that the "precise citation of legal authority" set forth in the cover memos provide more specific information. For example, the committees could ask the State Department to differentiate between agreements where the President relies only on his own constitutional authority (sole executive agreements) and those where the President relies on authority granted by Congress in prior legislation or a prior agreement. When an agreement relies solely on the Constitution, the committees could request that it be labeled a "sole executive agreement." For any agreement that is not a sole executive agreement, the State Department could be asked to list one legal authority on which it primarily relies and to explain the relevance of any additional authority.

Of course, without legislation, these committee requests would not have the force of law. Historically, however, the State Department has sought to accommodate reasonable requests of the congressional committees that oversee its work. Congress also has tools at its disposal to force the executive branch's hand, if it wishes - for example, it could hold up approval of executive branch appointees or even threaten to withhold appropriations.

Again, such reforms are not likely to be as effective as those implemented through legislation. But they would nevertheless be an improvement over the status quo. Moreover, if the congressional committees made clear their intent to carry out such reforms even without executive branch cooperation, that could blunt opposition by the executive branch to legislative reforms. Indeed, the executive branch might perceive that it would be in a better position during a legislative reform process to articulate any concerns that it may have about what is feasible, and about the possibility that particular reforms could undermine its conduct of foreign affairs. Moreover, in such a process, the executive branch might be in a better position to seek from Congress whatever resources it will need to implement the transparency reforms. Importantly, as we have noted, some of the reforms we have proposed are in the interest of the executive branch itself, but it may need additional resources to carry them out.

\section{CONCLUSION}

Today, the United States makes binding international commitments almost entirely through the practice of executive agreements. But, as this Article has shown, the transparency regime that is supposed to regulate these agreements is not working. The goals that Congress set for this regime are not being met, and there is substantial noncompliance with the statutory and regulatory requirements that have been put into 
place. Moreover, not only is the practice of executive agreements insufficiently transparent to Congress and the public, but it is also insufficiently transparent even to the executive branch itself. There is no normative justification for the current state of affairs, which is the product of disorganization within the executive branch, a failure by Congress and the executive branch to allocate sufficient resources to ensure compliance with the law, and outdated regulations and institutional practices. This Article suggests relatively modest reforms that, if adopted, would make it easier to ensure that agreements are properly authorized and to achieve Congress's original goals in establishing the transparency regime, all without seriously affecting the executive branch's flexibility in foreign affairs. 


\section{Appendix A: Methodology}

To obtain the cover memos, which have not previously been made public, we filed a FOIA request on behalf of the Yale Law School Center for Global Legal Challenges. The request was as follows:

We respectfully request that the Department provide to us all records documenting the "precise citation[s] of legal authority" for unclassified international agreements (other than treaties) submitted to the President of the Senate and Speaker of the House of Representatives pursuant to I U.S.C. $\S$ I 2 b(a) and 22 C.F.R. $\S$ I 8 I.7(c), during the last four Presidential administrations (i.e., between the dates of January 20 , I 989 , and January $20,2017)$. Our understanding is that all records responsive to this request are retained within the Office of the Assistant Legal Adviser for Treaty Affairs.

We are requesting these records to promote increased transparency regarding the thousands of international agreements concluded between foreign states and the U.S. government over the last four administrations. Many of these agreements have had a significant impact on the nation's economic and security interests. Indeed, international agreements regulate numerous subjects of public concern, including trade policy, nuclear energy, criminal law enforcement, and environmental protection. Given the farreaching impact of international agreements on American society, it is critical that the public has a complete understanding of their basis in U.S. law. ${ }^{342}$

When we received no response for 224 days, we filed a complaint in the U.S. District Court for the District of Connecticut alleging that "State's failure to make available the records requested by the Center for Global Legal Challenges in a timely manner violates FOIA and State's regulations promulgated thereunder." 343 We also argued that "State's failure to make available for public inspection in an electronic format all records documenting the 'precise citation[s] of legal authority' for unclassified non-Article II treaty international agreements ... violates FOIA." 344

The Department of State agreed to settle the suit, providing us with the cover memos attached to Case Act reports for the last four presidential administrations. Over the course of six months, we received 5,5 I8 cover memos. After a query to the State Department about gaps we had identified, we received another production of $\mathrm{I} 7 \mathrm{I}$ additional docu-

342 Letter from authors to Freedom of Information Officer, U.S. Dep't of State 2 (Mar. I6, 20I7) (on file with the Harvard Law School Library) (quoting 22 C.F.R. § I8I.7(c) (20I9)).

343 Complaint II 37, Yale L. Sch. Ctr. for Glob. Legal Challenges v. U.S. Dep't of State, No. I 7cv-02042 (D. Conn. Dec. 7, 20I7) (citation omitted) (citing 5 U.S.C. $\left.\$ 55_{2}(a)(3)(A),(a)(6)(A)\right)$.

344 Id. II 45 (quoting 22 C.F.R. $§$ I 8I.7(c)). We were represented by the students and faculty of the Yale Law School Media Freedom Information Access Clinic. We are especially grateful to Hannah Block-Wehba, Charles Crain, Diana Lee, and Paulina Perlin. 
ments. The Department of Justice's explanation for the failure to produce initially these documents was as follows: "This new material was not found in the agency's initial searches because State only searched the classified system since it was the practice of the Office of the Legal Adviser to store material associated with the requested reports under the Case Act on the classified system." 345 This was striking because the agreements produced were not classified. Although the attorneys responding to the FOIA request refused to explain why the agreements were stored on a classified system, subsequent interviews revealed that unclassified agreements are stored on a classified system because the computer systems do not permit reports to be sent to the "front office" for approval except through the classified system.

To begin our analysis of the memos, we separated the 5,689 agreements and made them all text searchable. ${ }^{346}$ With few exceptions, each cover memo shares a consistent format. Using a text-scraping program, we pulled the key identifying information as outlined in the Codebook in Appendix B. We also cross-referenced the agreements with the TIAS database, the Case Act Reports database, and HeinOnline, where available. ${ }^{347}$ If we identified a cross-reference, we recorded the relevant identifying number for those collections.

Almost all of the cover memos include a section labeled "legal authority" (twelve of the cover memos are missing this section). Using a data-scraping tool, we recorded the legal authorities cited for each agreement. We then verified the recorded information for each agreement, to ensure that there were no errors. From this, we developed a list of legal authorities that are cited in at least one cover memo. A team of five law student research assistants then read these statutory authorities and categorized each as falling into one of five categories, as described in Part II.

345 Email from John Larson, U.S. Dep't of Just., to Charles Crain, YLS Media Freedom \& Info. Access Clinic (May 2, 2019, 4:27 PM) (on file with the Harvard Law School Library).

346 Andrea de Sa, YLS '20, oversaw the creation of databases and database comparison, with the assistance of Ayoub Ouederni, YLS '2 I. To ensure accuracy, undergraduate research assistants double-checked that the correct information had been pulled and that there were no typographical errors. Five Yale undergraduates - Kelsea Jeon, Christopher Kim, Julianna Lai, Max Obmascik, and John Park - assisted.

347 For more information on the matching process, see supra note 185. 


\section{APPENDIX B: CODEBOOK}

For each cover memo that we received, we recorded the following information:

Unique No. We assigned a unique number to each cover memo.

Bates No. The State Department assigned a nine-digit Bates number to each cover memo, typically following the format Co65 I 2345. The Bates number is stamped on the top and bottom of each page. The same Bates number was sometimes assigned to different cover memos. For example, the number Co654I494 was assigned twice, to two different cover memos: Co654I494(I) and Co654I494(2).

Stamped No. Many of the cover memos we received also have a handwritten or stamped number on the upper-right-hand side of the page. The stamped number is typically a five-digit number, such as I2-I34 or 04-II I. The number sometimes, though not always, corresponds to the TIAS or Case Act Reports database number. For example, Co6540799 is stamped with the number 2013-0I72 but refers to Case Act Reports database No. 2013-0003 and TIAS No. I2-II30.r. Additionally, the stamped numbers are not always unique. For example, Co654I6I5 and Co6542530 refer to different agreements but are both stamped I4-404.

$T I A S$. If the agreement was available in TIAS, the identifying number is provided with a hyperlink to the database.

Case Act Reports Database. If the agreement was available in the Case Act Reports database, the identifying number is provided.

HeinOnline. If the agreement was available on HeinOnline, the identifying number is provided.

Cover Letter Title. This title usually indicates the subject of the agreement, the counterparty, and the dates that the agreement was signed or came into effect. For example, Co6538588 has the following title: "Background Statement Concerning the Agreement Between the United States and Estonia Extending the Agreement Of June I, I992 Concerning Fisheries off the Coasts of the United States. Effected by Exchange of Notes at Tallinn March I I \& May I2, I994. Entered into Force September I, I 995." From the title, we were also able to derive:

- Country. The counterparty state or international organization. 
- First Signed Date. The first signed date represents the date that the agreement was first signed. In the aforementioned case, that date is March I I, I994.

- Last Signed Date. The last signed date represents the last date on which the agreement was signed. In the aforementioned case, that date is May I2, I994.

- Entry into Force. This date represents the date of entry into force, if any is given. In the aforementioned case, that date is September I, I995.

Highest Rating. This is the highest rating among the nonconstitutional references cited in the "Legal Authority" section.

Category//Subcategory. This is the subject matter category and subcategory that we assigned to the agreement.

Legal Authority (as it appears). All but a small number of the memos have a section titled "Legal Authority." Some cover memos cite only the Constitution as a legal authority. Others cite various statutory provisions. We recorded the legal authority precisely as it appears - often as a string cite of several authorities. We then separated out each cited legal authority. The database includes each authority that we identified for each agreement:

- Constitutional Reference. If there is a reference to the Constitution, it is listed here as it appears.

- Reference $I$. If there is a reference to a nonconstitutional authority, it is listed here.

- Rating $I$. If there is a reference to a nonconstitutional authority, its coding is listed here.

- Reference 2. If there is a reference to a second nonconstitutional authority, it is listed here.

- Rating 2. If there is a reference to a second nonconstitutional authority, its coding is listed here.

(The "Reference" and "Rating" columns are each repeated another nine times, to accommodate up to eleven separate references.) 


\section{Figure 4: Sample Cover Memo}

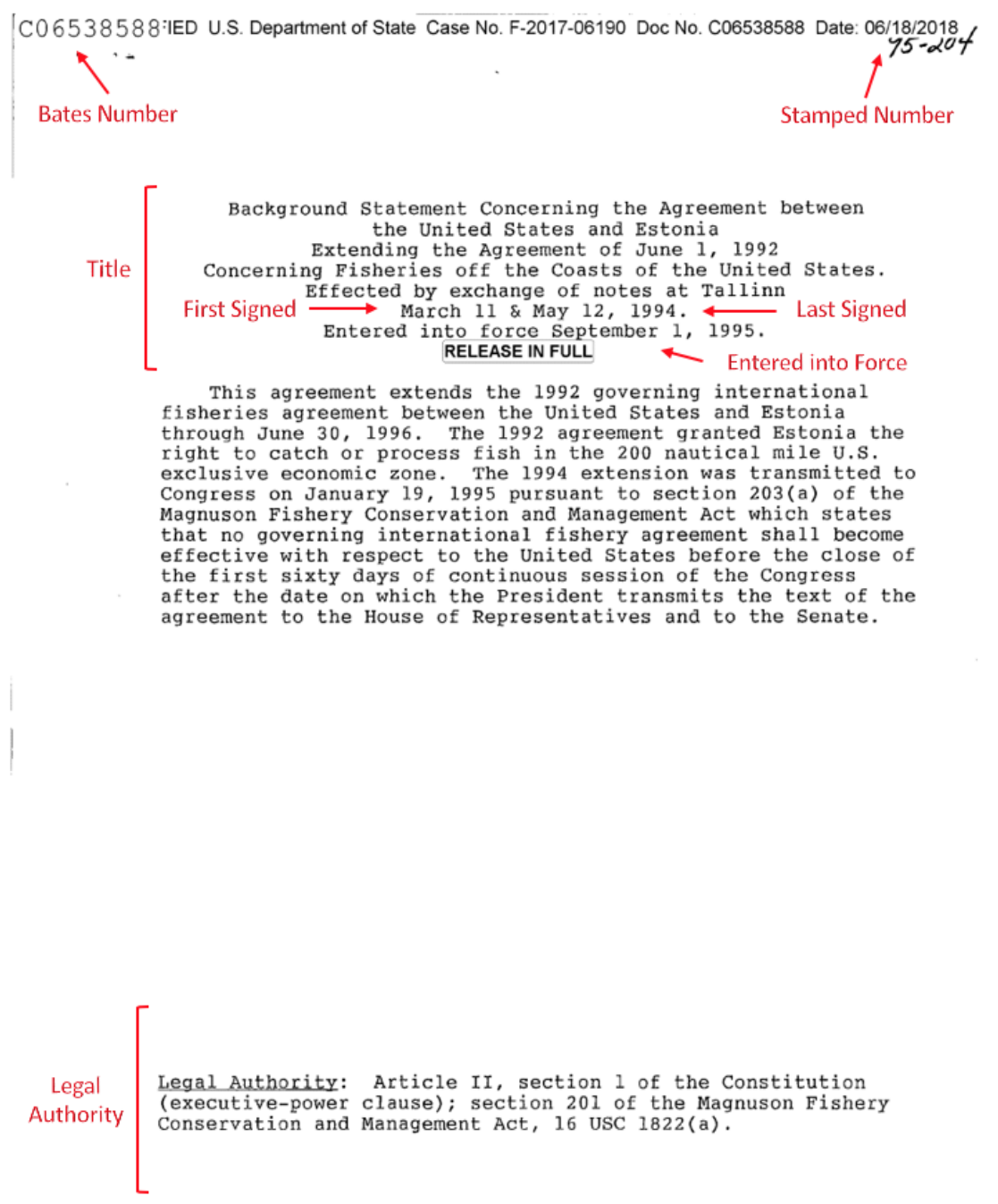

